Filologie medievali e moderne 25

Serie occidentale 21

\title{
Knowledgescape \\ Insights on Public \\ Humanities
}

edited by

Eugenio Burgio, Franz Fischer, Marco Sartor 
Knowledgescape

Filologie medievali e moderne Serie occidentale

Serie diretta da

Eugenio Burgio

$25 \mid 20$

Edizioni

Ca'Foscari 


\section{Filologie medievali e moderne}

\section{Serie occidentale}

Direttore | General editor

Eugenio Burgio (Università Ca' Foscari Venezia, Italia)

\section{Comitato scientifico | Advisory board}

Massimiliano Bampi (Università Ca' Foscari Venezia, Italia)

Saverio Bellomo † (Università Ca' Foscari Venezia, Italia)

Marina Buzzoni (Università Ca' Foscari Venezia, Italia)

Serena Fornasiero (Università Ca' Foscari Venezia, Italia)

Tiziano Zanato (Università Ca' Foscari Venezia, Italia)

\section{Serie orientale}

\section{Direttore | General editor}

Daniela Meneghini (Università Ca' Foscari Venezia, Italia)

\section{Comitato scientifico |Advisory board}

Attilio Andreini (Università Ca' Foscari Venezia, Italia)

Giampiero Bellingeri (Università Ca' Foscari Venezia, Italia)

Piero Capelli (Università Ca' Foscari Venezia, Italia)

Emiliano Bronislaw Fiori (Università Ca' Foscari Venezia, Italia)

Antonella Ghersetti (Università Ca' Foscari Venezia, Italia)

Bonaventura Ruperti (Università Ca' Foscari Venezia, Italia)

e-ISSN 2610-9441

ISSN 2610-945X

URL http://edizionicafoscari.unive.it/it/edizioni/collane/filologie-medievali-e-moderne/ 


\section{Knowledgescape Insights on Public Humanities}

a cura di

Eugenio Burgio, Franz Fischer, Marco Sartor

Venezia 
Knowledgescape. Insights on Public Humanities

edited by Eugenio Burgio, Franz Fischer, Marco Sartor

(c) 2021 Eugenio Burgio, Franz Fischer, Marco Sartor for the text

(c) 2021 Edizioni Ca' Foscari - Digital Publishing for the present edition

\section{(a) (1)}

Quest'opera è distribuita con Licenza Creative Commons Attribuzione 4.0 Internazionale This work is licensed under a Creative Commons Attribution 4.0 International License

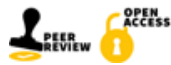

Qualunque parte di questa pubblicazione può essere riprodotta, memorizzata in un sistema di recupero dati o trasmessa in qualsiasi forma o con qualsiasi mezzo, elettronico o meccanico, senza autorizzazione, a condizione che se ne citi la fonte.

Any part of this publication may be reproduced, stored in a retrieval system, or transmitted in any form or by any means without permission provided that the source is fully credited.

Certificazione scientifica delle Opere pubblicate da Edizioni Ca' Foscari - Digital Publishing: tutti i saggi pubblicati hanno ottenuto il parere favorevole da parte di valutatori esperti della materia, attraverso un processo di revisione doppia anonima, sotto la responsabilità del Comitato scientifico della collana. La valutazione è stata condotta in aderenza ai criteri scientifici ed editoriali di Edizioni Ca' Foscari, ricorrendo all'utilizzo di apposita piattaforma.

Scientific certification of the works published by Edizioni Ca' Foscari - Digital Publishing: all essays published in this volume have received a favourable evaluation by subject-matter experts, through a double blind peer review process under the responsibility of the Scientific Committee of the series. The evaluations were conducted in adherence to the scientific and editorial criteria established by Edizioni Ca' Foscari, using a dedicated platform.

Edizioni Ca' Foscari - Digital Publishing

Fondazione Università Ca' Foscari | Dorsoduro 3246 | 30123 Venezia

https://edizionicafoscari.unive.it|ecf@unive.it

1a edizione agosto 2021

ISBN 978-88-6969-542-1 [ebook]

ISBN 978-88-6969-543-8 [print]

This initiative was realised by Humanities for Change international network in collaboration with the Venice Centre for Digital and Public Humanities (VeDPH) of Ca' Foscari University of Venice and the Faculty of Philology of the University of Banja Luka and received funding from Ca' Foscari University of Venice under the student activities funds programme (year 2021, 1st semester).
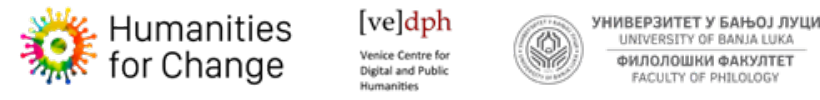

Knowledgescape. Insights on Public Humanities / edited by Eugenio Burgio, Franz Fischer, Marco Sartor - 1. ed. - Venezia: Edizioni Ca' Foscari - Digital Publishing, 2021. - 174 pp.; $23 \mathrm{~cm}$. - (Filologie medievali e moderne; 25). - ISBN 978-88-6969-543-8.

URL https://edizionicafoscari.unive.it/it/edizioni/libri/978-88-6969-543-8/

DOI http://doi.org/10.30687/978-88-6969-542-1 


\section{Knowledgescape}

Insights on Public Humanities

edited by Eugenio Burgio, Franz Fischer, Marco Sartor

\section{Abstract}

This volume, which collects the proceedings of the international study day Intersections. New Perspectives for Public Humanities, aims at shedding light on the often complicated and chaotic 'texture' of public humanities in order to foster a less marginal place for this field of study. The choice to focus the analysis on a selection of case studies that includes history, cultural heritage, archaeology, and literature leads to redesigning a profile whose main feature is to create bridges between specialised knowledge domains and large audiences and identifying methods and models that can make humanistic knowledge 'actionable' in our society.

Keywords Public humanities. Digital humanities. Public history. Museology. Public engagement. Public archaeology. Citizen science. Cultural heritage. Literary canons. Knowledge design. Intersections. 



\section{Knowledgescape}

Insights on Public Humanities

edited by Eugenio Burgio, Franz Fischer, Marco Sartor

\section{Acknowledgements}

By publishing this volume, which contains the proceedings of the international study day Intersections. New Perspectives for Public Humanities, I would like to thank all those who, in various ways, have contributed to its realisation. In particular, I am grateful to Eugenio Burgio, director of the series that hosts it, and to Franz Fischer, director of the Venice Centre for Digital and Public Humanities (VeDPH), for accepting to edit this work with me. A special mention is due to the VeDPH and its members for their constant support over these months and for the inspiring opportunities they have offered me since its foundation. I also express my gratitude to Irene Mamprin (Università Ca' Foscari Venezia), Filippo Luca Sambugaro (Università degli Studi della Campania "Luigi Vanvitelli") and Emmanuela Carbé (Università degli Studi di Siena) for their attentive and passionate reading of the essays and for the insights and discussion they shared, to Rebecca Ivković for suggesting the title of the volume, to Francesca Masiero (University College London) for the linguistic check.

The conference and its proceedings are initiatives carried out within the international network Humanities for Change (https://humanitiesforchange. org) with the valuable collaboration of VeDPH and the Faculty of Philology of the University of Banja Luka, and funded by Ca' Foscari University of Venice. By thanking those who took part in its organisation and realisation (the students, Francesco Venturini, Damiano Pellizzaro, Giorgia Cappellina, Francesca Leorato Boschi), I would like to mention, in addition to the speakers whose essays are included in this volume, Michelangela Di Giacomo (M9 - Museo del Novecento), Paola Italia (Alma Mater Studiorum Università di Bologna), Silvia Mazzucotelli Salice (Università Cattolica del Sacro Cuore di Milano), Alberto Trentin, and the discussants Stefano Adamo (University of Banja Luka), Giulia Pellizzato (Harvard University) and Gaia Tomazzoli (Università di Pisa). A special thanks to Jeffrey Schnapp (Harvard University) for his interest in Humanities for Change and for his kind availability to take part in the event.

Finally, I would like to thank the Rector Tiziana Lippiello, here in her position of President of Fondazione Università Ca' Foscari, of which Edizioni Ca' Foscari is part. A sincere acknowledgement to the Director Massimiliano Vianello for his generous and competent availability and to the editor Mariateresa Sala for her diligent care and constant editorial support throughout the publication. Without the financial support of Ca' Foscari University of Venice this volume would not have seen the light of day.

These pages, conceived and written as a table to cling to in the midst of the proclaimed hostility and the darkness of the times, are dedicated, although all is now lost, to Poetry in a world of prose. 



\section{Table of Contents}

Foreword

Eugenio Burgio

Introduction

Marco Sartor

Public History e università italiana: esperienze, criticità e prospettive

Digital Technologies for the Promotion of Cultural History Best Practices in Matera, the European Capital of Culture in 2019

Fascist Monumentality in Bolzano and Trieste:

Can Public History Help to Deal with it?

Iris Pupella-Noguès

Digital Engagement, Diversity and Access

in Museum Education

Carlo Corsato, Kate Devine

Una piccola provocazione. La pandemia e i modelli della Nouvelle Muséologie

Antonietta Biondi

Heritage Thinking. Approaching Communities with Communication in the Venice Countryside Elisa Corrò

Le Ortique: un progetto collettivo e digitale per riscoprire le artiste dimenticate 

And that heart will no longer respond

To my voice, exulting and grieving.

Everything is over... And my song drifts

Into the empty night, where you no longer exist.

(A. Achmàtova 1953)

To Poetry in a world of prose 



\section{Knowledgescape}

Insights on Public Humanities

edited by Eugenio Burgio, Franz Fischer, Marco Sartor

\section{Foreword}

\section{Eugenio Burgio}

Università Ca' Foscari Venezia, Italia

It is probably an unusual choice that a series of "Filologie medievali e moderne" should host a volume entitled Knowledgescape. Insights on Public Humanities, and even more eccentric if, scrolling through the index of contributions, one immediately realises that none of them - with the exception of the final essay (on the Le Ortique project) - deals with philological and/or literary themes and methods. But, however far-fetched, the choice has some foundation.

Knowledgescape brings together some of the papers presented at the study day Intersections. New Perspectives for Public Humanities held in the Zoom virtual space on 3 December 2020. Intersections was organised by Humanities for Change (https://humanitiesforchange.org), a network of young students and scholars committed to thinking about and acting on the relations between the humanities and socio-economic 'realities', starting from the assumption that it is good for the studia humanitatis to leave the reassuring academic enclosure and immerse themselves in the 'world out there' (and, conversely, it does not hurt the 'world' to maintain a close relationship with the studia). Commitment and assumption are not new, nor is especially commitment to the dissemination of humanistic knowledge and its innervation in the body of society. However, it is stimulating (and also comforting) that, once again, a new generation of educated women and men is climbing on the shoulders of the less new

The Author would like to thank Francesca Masiero (University College London) for the translation check of this paper. 
generations, to look further afield, in this case, towards the largely unknown horizon opened up by the digital turn. It is stimulating for everyone, I would say, but especially for us, lovers of the humanities. The 'digital revolution' summons us to a tight debate on the reasons for scientific practices and coexistence with other types of knowledge in the social landscape and, consequently, on 'what to do?'. A debate that not only concerns communication/dissemination of research, but also, in some cases, the methodological foundations of the disciplines. Hence, the great usefulness of meetings such as Intersections.

In its original articulation, the study day consisted of four panels, Public History ("A Glance at Public History"), artistic heritage ("Art, Museum and Cultural Heritage: Some Insights"), dissemination of research ("Beyond the Academy. Dissemination of Research and Employment"), and textual tradition ("The Contribution of Digital to the Tradition of Literary Texts"). Even if some of the contributions to the fourth panel did not result in written form, the other essays give a sufficiently articulated idea of the problems on the ground, which are not exclusive to historical or artistic-museum research but also concern literary traditions as part of the cultural heritage of humanity. The reconstruction, preservation and transmission of textual traditions, understood in the broadest (one might say 'anthropological') sense of the term, regardless of the form and consistency of material supports, are at the heart of humanistic knowledge. Having identified in the 'text' the essential articulation of symbolic-cultural production in a given context is perhaps one of the most important intellectual acquisitions in the humanities in the last thirty years. This allows philologists to look at what is happening in other disciplinary fields, to derive stimuli and matter for reflection for their practices and to maintain a vital relationship with humanistic research in the broadest sense of the term. For this reason, it is a great pleasure to welcome Knowledgescape in our "Filologie medievali e moderne" series. 


\title{
Introduction
}

\author{
Marco Sartor
}

Università di Parma, Italia

Summary 1 Intersections. -2 Public Humanities. -3 Knowledgescape.

\section{Intersections}

The essays that constitute this volume outline a in some ways comprehensive overview of a selected range of experiences that have arisen in the field of Public Humanities, albeit inevitably limited to a few privileged research strands and conducted by focusing more on specific case studies than on their underlying theoretical and methodological frameworks. ${ }^{1}$ At the basis of such approach there is primarily what is both a judgment of value and a petition of principle about the role and function to assign to Public Humanities in the social context of our time: that it, in short, performs a task tenaciously clinging to the practical sphere, as also recognised by several recent contributions (Smulyan 2021) and made clear by associations with contiguous categories such as applied humanities (Steinberg 1974; Nikitina 2009) and public engagement (Ross 2012; Cooper 2014). ${ }^{2}$

Thus, the attempt to sketch a compelling overview of the socio-cultural instances that, since the middle of the last century, have contributed to the launching of projects and grants in the field of Public

1 The Author would like to thank Francesca Masiero (University College London) and Mariateresa Sala for the translation check.

2 Particularly revealing in this regard are Jacobson's concluding thoughts on the volume Doing Public Humanities, which emphasizes that "Public Humanities is in the doing" (italics in the original text) and, a little further on, states that "Public Humanities, properly conducted, is a verb, not a noun" (Jacobson 2021, 165). 
Humanities and, similarly, the intention to provide a complete historical synthesis of the main phases and moments that have fostered their development (for which see Schroeder 2017; 2021) do not align with such a perspective. This volume, instead, deliberately unfolds in snapshots, by presenting projects, experiences and case studies related to the historical, artistic, archaeological and literary areas, in the conviction that each of those images has its own value without the need for other explanations. Their succession is then in charge of restoring the overall sense and identifying the various threads that make up the warp of the publication.

In this sense, therefore, is to be understood the concept of 'insight' present in the subtitle of the volume and here aimed to account for the heterogeneity and autonomy of the individual contributions, which, however, do not disdain to be collected (or to reveal themselves) a posteriori within a project endowed with its multiplicity and coherence. In particular, the overall design of such a project is to be found in the concept of 'intersection' as the unifying element - even before being its interpretative key - of the essays gathered here. It is not by chance that the study day whose proceedings are published in this volume bears the title Intersections. New Perspectives for Public Humanities, to underline how in the varied thematic excursion of the contributions the pivotal and, in some ways, ordering function resided in the encounter with a different reality from the original one, hence the concept of intersection. ${ }^{3}$

Notwithstanding the variety of interpretations that have arisen and to which this term applies, it seems particularly perspicuous and purposeful - at least in the mind of the Author - the echo of a successful book by the Swedish-American writer Frans Johansson, where 'intersection' is defined as:

a place where different cultures, domains, and disciplines stream together toward a single point. They connect, allowing for established concepts to clash and combine, ultimately forming a multitude of new, groundbreaking ideas. (Johansson 2006, 2)

More specifically, the term occurs primarily in the combination of concepts from different 'fields', namely "disciplines, cultures, and do-

3 The initiative, which took place online on December 3, 2020, was organised with funds from Ca' Foscari University of Venice by the international network Humanities for Change (https://humanitiesforchange.org), in collaboration with the Venice Centre for Digital and Public Humanities (VeDPH) and the Faculty of Philosophy of the University of Banja Luka. The book of abstracts of the conference is available on the event page: https://bembus.org/intersections; the recordings of the talks are available on YouTube at: https://www.youtube.com/playlist?list=PL30jJCPOsmlqQ ZtdwC6m6vgEv0Qdxz॰q๑. 
mains" in which one can specialise "through education, work, hobbies, traditions, or other life experiences" (Johansson 2006, 16), with the aim of fostering the development of 'intersectional ideas' characterised by innovation and creativity. It goes without saying that the intersection is not realised ea ipsa in the mere juxtaposition of concepts from different fields, but is rather qualified as a 'place' able to significantly increase the development of unusual connections that can organise one or more domains of knowledge in new and particularly effective ways.

The set of findings collected so far lends itself to manifold interpretative consequences, which are at the centre of the itinerary unfolded in these pages and which appear to be fundamentally connected to three main nuclei, corresponding to as many constitutive elements of the concept of intersection. First of all, it should be noted that, in order to take place, an intersection requires a space (real or virtual) that can encourage the interaction of different fields of knowledge. This also explains the reference to the Medici court in the title of Johansson's book, where it is considered the "epicentre of a creative explosion" $(2006,3)$ and a result of a successful confluence between the 15th and 16th centuries of some of the most prominent cultural figures of the time. In the first decades of the new millennium, the venues capable of recreating the 'Medici effect' by supporting the development of innovative and creative ideas are represented, in the university scenario, by inter-departmental research centres and international networks of public and private institutions. In other words, institutions that - individually or as part of larger networks - promote the international mobility of scholars and welcome hybrid profiles, including those from outside academia and from the entrepreneurial field, in order to work collaboratively as a team to increase knowledge production and the development of innovative ideas. This interweaving of motivations and principles is at the base of some leading international realities: from the MetaLab(at)Harvard ${ }^{4}$ to the MIT Media Lab, ${ }^{5}$ from the Venice Cen-

4 Founded in 2011 and directed by Jeffrey Schnapp, who also previously served as director and founder of the Stanford Humanities Lab (1999-2009), the MetaLab(at)Harvard (https://metalabharvard.github.io) is "an idea foundry, a knowledge-design lab, and a production studio experimenting in the networked arts and humanities". On the history and projects of the centre, see the recording of the event The Lab of Ideas: a Conversation with Jeffrey Schnapp organised on December 16, 2020 by VeDPH in collaboration with Humanities for Change: https://www.youtube.com/watch?v=SU6GUvo@dQg.

5 The MIT Media Lab (https://www.media.mit.edu) was founded in 1985 by Nicholas Negroponte and Jerome Wiesner. It brings together designers, engineers, artists, and scientists who are involved in the development of interdisciplinary research projects on communities and environments (social robotics, tools for learning, models for sustainable cities) that encompass art, science, design, and technology. 
tre for Digital and Public Humanities (VeDPH) ${ }^{6}$ to the London Interdisciplinary School (LIS). ${ }^{7}$

From these considerations stems the second core of concern, already peculiar to the aforementioned realities, namely the use of an interdisciplinary approach in all phases of the development of the intersectional idea, from the composition of the team to the design of the research project. Underlying this is the belief that different knowledge communities can "integrate the insights from multiple disciplines to generate a superior understanding of a particular question" (Szostak, Gnoli, López-Huertas 2016, 1), ${ }^{8}$ that is to create the conditions to considerably increase the likelihood that an "explosion of remarkable innovations" will occur (Johansson 2006, 15). In this regard, references to the 'explosion', which pervade Johansson's essay on various occasions, are of undoubted symptomatic value and constitute, for the purposes of our discussion, the third and last focus of interest. It is evident that in the Medici effect, intersectional ideas constitute a chaotic universe within which they intertwine, merge and, not lastly, clash. That is why the production of knowledge takes place primarily in their 'collision', to use a term particularly dear to Michael John Gorman (2020). Although with some substantial differences, the Medici effect shares multiple points of tangency with the 'edge effect' that occurs in ecology when, in a transition zone between two ecosystems, ecological communities influence each other and generate a considerable increase in biodiversity, both in terms of number and variety of life forms (Levin 2009, 780). According to Gorman (2020), the methodological principles underlying the 'edge effect' can be applied to the creation of new types of cultural environments that, by nurturing the contamination and collision of ideas from different fields of knowledge (science, art, design, technology), foster the development of new critical conversations and creative approaches to humanistic knowledge. ${ }^{9}$ Hence the establishment of

6 The VeDPH (https://unive.it/vedph), founded in June 2019 and directed by Franz Fischer, is part of the Department of Humanities (DSU) at Ca' Foscari University of Venice. On the activities of the centre, cf. § 3 of Stefano Dall'Aglio's essay in this volume.

7 The London Interdisciplinary School (https://www.londoninterdisciplinaryschool.org), which was founded by a group of entrepreneurs and educators in 2017 and is directed by Carl Gombrich, proposes to deliver from the a.y. 2021-22 a Bachelor of Arts (BASc) course in Interdisciplinary Problems and Methods. The course of study offers a cross-disciplinary approach, providing students with knowledge and methods from the arts, sciences, and the humanities.

8 Although primarily focused on STEM disciplines, see the first chapter of this volume devoted to the role of interdisciplinarity in research and teaching, also with reference to the design of research projects (Szostak et al. 2016, 1-33).

9 It is remarkable that the first volume of magazén was dedicated to a topic related to those discussed here, namely the concept of 'fusion', which "serves well to embrace every possible kind of merger, interrelation, joint, blend, interpenetration, interdepen- 
fertile 'border spaces' that, in conjunction with traditional cultural institutions, contribute to the creation of new forms of experience.

In this framework are to be ascribed the studies contained in the volume, which display, in a more or less explicit way, their relationship with the instances and methodological principles on which we have been discussing up to now. Despite the unavoidable practical impetus that - as we have seen - stands as a constitutive character of Public Humanities, the essays do not miss to tackle some theoretical perspectives aimed at outlining the current state of the art and at identifying the main future challenges with reference both to the international context and to the Italian university system, as is the case with Stefano Dall'Aglio's paper. The article by Iris Pupella-Noguès, taking up the theoretical instances on Public History effectively illustrated by Stefano Dall'Aglio, presents some projects dealing with the fascist-era monuments of the cities of Bolzano and Trieste. The contributions by Francesca Vera Romano on Matera and Carlo Corsato and Kate Devine on the National Gallery have the merit of describing some experiences that involve active engagement of people with motor, visual or hearing disabilities, as well as the promotion of inclusive practices for the fruition and valorisation of cultural heritage. Antonietta Biondi's essay is also to be traced back to this perspective. Like the previous one by Carlo Corsato and Kate Devine, it has its fulcrum in museum experiences and in the changes brought about by the spread of pandemics. These interventions, essentially dedicated to history and art history, share with the following ones by Elisa Corrò on archaeology and by Alessandra Trevisan and Alice Girotto on literature the use of innovative methods for knowledge transmission. Specifically, the former presents several projects of public archaeology that are characterised by a strong innovative character, from the citizen science approach to the use of open data and neural interfaces; the latter aims to 'deform' the literary canon - notoriously exclusive heritage of academic circles - to give voice to forgotten artists through alternative communication channels, such as podcasts, videos, visual artworks, and open mic. Despite the thematic heterogeneity, these studies not only confront themselves with the experience of Public Humanities but also experiment, as far as possible, the use of innovative ways of conveying and producing knowledge, fostering the development of intersectional ideas between different domains. It is enough to consider, just as an example, how the valorisation of the Matera area - recognised by UNESCO as a World Heritage Site - does not only involve a generic use of digital technologies for the development of sustainable tourism, but the adopand practices of research in this wider field" (Fischer, Mantoan, Tramelli 2020a, 11). 
tion of experimental practices - from smart agriculture made possible thanks to the 5G network to blockchain technologies - that lead to the collision of ideas and the intersection of different profiles: scientists, computer scientists, and engineers, but also historians, art historians, and archaeologists.

\section{Public Humanities}

The discussion thus rebounds towards another pole that outlines the field of application of these studies and, in particular, the concept of Public Humanities. In the following pages, the considerations on the potentialities offered by the effects of intersections - as already mentioned - are not applied to the hyper-specialised domains of knowledge, but to specific cases of study whose main object is to be found in the outflow of knowledge from the university venues and the academic research centres. In short, the underlying assumption is that the studia humanitatis may provide a greater awareness of the complexity of the political, social and economic issues of our time and serve as an instrument of practical action, which is an essential prerequisite for a democratic society (Nussbaum 2010). This inevitably calls for a more accurate definition aimed at describing the scope of intervention of the Public Humanities and at identifying its main features. It is indeed a very challenging task, which cannot avoid considering the fact that up to now there is still no generally accepted definition which can clarify the nature of Public Humanities and, at the same time, differentiate it from more or less similar categories, such as civic and community engagement, applied humanities, service learning or public scholarship..$^{10}$ Therefore, it is not surprising that even one of the most remarkable theoretical contributions on Public Humanities (Schroeder 2021) aims to trace a history eo nomine of the expression rather than of the movement itself. However, given the inevitable need for an attentive demarcation of the field of intervention, one can agree with Schroeder in asserting that:

Public Humanities is the work of moving humanistic knowledge among individuals and groups of people. Some of the most common varieties of work are translational scholarship; cultural organizing; production of programs, plays, performances, tours, festivals, exhibits, or other audience-oriented humanistic activities. Others in-

10 It should be noted, incidentally, that the history of Digital Humanities is also accompanied by some difficulties in establishing a universally agreed definition, although in this case the theoretical discussion is considerably more consistent, as proved by the website https://whatisdigitalhumanities.com where 817 definitions provided by the participants of the 2009-14 editions of the Day of DH are collected. 
clude maker activities, particularly making art, music, writing, typically with an orientation toward an evidentiary basis and/or some form of expertise; and generally all ways of making meaning socially, or making personal meaning in public space. (Schroeder 2021, 6)

In the meaning that most closely resembles the current one, the expression Public Humanities became widespread as a result of the National Foundation on the Arts and the Humanities Act of 1965, ${ }^{11}$ with the start, since the 1970s, of Public Humanities programmes and grants funded by the National Endowment for the Humanities $(\mathrm{NEH})$, albeit at least until the beginning of the following decade the concept continued to cover a purely nominal character.

If the term Public Humanities is still shrouded in a partly nebulous physiognomy, ${ }^{12}$ the role of the public humanist appears more clearly defined thanks to some contributions that describe the most frequent activities and principles that inspire these professionals (Ellison 2013; Zinn 2008). Similarly, the scope of intervention of some of the disciplines that converge under the more general category of humanities is also quite well defined. Particularly emblematic in this regard is the case of Public History, which has been endowed since 2012 with an international federation (namely the International Federation for Public History) and has under its belt, in addition to the establishment of several university courses, the organisation of annual conferences and the editing of a scientific journal. ${ }^{13}$ This is discussed in more detail by Cauvin $(2018 ; 2021)$ and, among the authors of this volume, also with specific reference to the Italian context, by Stefano Dall'Aglio and Iris Pupella-Noguès. Nor does there seem to be a lack of adequate feedback for public art (Cartiere 2008) and public archaeology (Moshenska 2017), while the issues that involve the philological-literary field, at least in the Italian context, are still at an early stage. Nevertheless, it is significant to note that a few seminal remarks appear in some major works on digital philology and digital

11 The Act can be read in the legislative section of the NEH website at: https://www. neh.gov/about/history/national-foundation-arts-and-humanities-act-1965pl-89-209.

12 The definition provided in the white paper of the North Eastern Public Humanities Consortium (NEPH) is only partially acceptable in this work as it is strongly anchored to US contexts and thus full of political references which are extraneous to the context of the essays that constitute this volume: "Public Humanities strives to locate, cultivate, and build upon commonalities through broadly collaborative practices of story-telling; of historical inquiry, recovery, and acknowledgements; and of artistic expression, aimed at rededicating the American university as a true community resource" (Jacobson 2021, 168-9). Finally, although not providing a definition, Lubar's contribution is particularly clarifying (2014).

13 It is the semi-annual journal International Public History, founded in 2018 and published for De Gruyter. 
textual scholarship (see Mastandrea 2017 and Zaccarello 2019), attracting the attention of the most eminent scholars at international level. ${ }^{14}$ As early as 2017, Marco Santagata warned that:

Dissemination is a task that literary studies cannot shirk, if it is true that helping the reader to understand and keep alive in the present literary and cultural traditions of the past is perhaps the primary purpose of philological work. However, it does not seem, at least in Italy, to be at the forefront of the thoughts of scholars, especially those dealing with the oldest texts. (Santagata 2017,6)

However, the most comprehensive investigation of this issue is undoubtedly due to Paola Italia who, in a recent monograph (2020), proposes to combine the digital and public instances of philology and literature starting from a study of the changes of the status of the texts caused by the digital revolution. In particular, her acknowledgement is accompanied by a strong exhortation to consider literary texts as goods belonging to the cultural heritage of a society.

In a cultural system that considers texts as common goods, a founding part of our cultural heritage, protecting them, taking care of them [...], guaranteeing their quality and promoting their diffusion, become real social tasks, even more than a cultural ones, a duty that every scholar should set himself. (Italia 2020, 13)

Hence the invitation, addressed primarily to scholars, to pay renewed attention to the textual tradition and to the facies of online texts. At the base of such demand there is the acknowledgement, indeed quite paradoxical, that the common reader, defined 'Google reader', finds on the Internet texts that are generally incorrect or approximate, arbitrarily modernised or that never existed - in other words 'junk food' -, while up-to-date and accurate editions by the most authoritative scholars - Proust's madeleines - are printed in a few dozen copies and remain confined in libraries that are barely accessible to most people. ${ }^{15}$ For this reason, the wish invoked by Italia for a deeper attention from scholars towards collaborative platforms such

14 It should be stressed, however, that the international framework is more complex and articulated and includes several experiences of crowdsourcing editions, such as the Bentham Project (https://blogs.ucl.ac.uk/transcribe-bentham/) developed within University College of London, social editions (Siemens et al. 2014) and community-driven editions (Brumfield 2017).

15 These thoughts are not without important implications on research funding if we consider that most of the investments are allocated to the preparation of editions that will have a limited circulation, whereas the 'Google-reader' will continue to rely on outdated editions, often randomly chosen on the basis of their availability on the web. 
as Wikisource to encourage the circulation of correct, updated and trustworthy editions of the texts that constitute our cultural heritage is highly shareable. ${ }^{16}$

Although the observations raised in these pages bear witness to the praiseworthy effort to bend the discussion on Public Humanities to a more or less philological-literary level, they reveal the sometimes invasive involvement of the digital component, which is extraneous to certain declinations of Public Humanities, such as festivals and exhibitions (Schroeder 2021). Nevertheless, the effort made by several parties to define the scope of intervention of the Public Humanities and confer a certain autonomy and academic dignity to the status of these expressions is commendable. In this sense, the foundation in 2002 of an excellence centre such as the John Nicholas Brown Center for Public Humanities and Cultural Heritage at Brown University ${ }^{17}$ has been an important catalyst for this strand of studies that has determined - among other things - the setting up of the first Master of Art programme in Public Humanities in the United States. Therefore, it is not surprising that scholars who gravitate (or have gravitated) around this institution are behind the publication of the volume Doing Public Humanities, edited by Susan Smulyan (2021), which qualifies as the most up-to-date and complete recognition of Public Humanities with contributions from the leading scholars at international level. At the same time, significant and seminal contributions are expected to come from the Palgrave Handbook of Digital and Public Humanities, edited by Anne Schwan and Tara Thomson of Edinburgh Napier University and now forthcoming from Palgrave. Equally high expectations are placed on the issues of the journal magazén, ${ }^{18}$ which has already stressed the importance of the public component on several occasions (Fischer, Mantoan, Tramelli 2020a; 2020b) and has provided pivotal contributions on this topic, including Heinisch's (2020) fundamental considerations on citizen humanities. ${ }^{19}$

16 These issues were the main focus of Paola Italia's talk at the study day. You can watch the recording of her presentation on the YouTube playlist of the event: https:// www.youtube.com/playlist?list=PL30jJCPOsmlqQZtdwC6m6vgEv0Qdxz○q๑.

17 For more information on the activities of the centre, please visit the website: https://www.brown.edu/academics/public-humanities/home.

18 Cf. the journal's page on the publisher's website: https://edizionicafoscari. unive.it/it/edizioni4/riviste/magazen/info.

19 More generally, for an overview (constantly updated) on the state of Public Humanities (research centres, publications, training opportunities and projects), see the page edited by the author with the support of Irene Mamprin: https://bembus.org/ public-humanities. 


\section{Knowledgescape}

By referring to Schroeder (2017; 2021) for an examination of the political and social influences (extraneous to the contributions included in this volume) that have characterised the evolution of the Public Humanities in the past decades, a last path which is likely to offer good results in the definition of Public Humanities trends is linked to the recognition of some thematic constants and recurrent nodes that preside over the essays collected in this volume. In this sense, a first nucleus of considerations could involve the function of the academic institutions and, in particular, the apparent paradox determined by their involvement in instances that programmatically propose to convey humanistic knowledge in environments external to university campuses. However, there is no inconsistency in such an attitude since it is one of the tasks of universities to deal not only with academic research stricto sensu, but also with large-scale dissemination of results, even if in many national realities - including Italy - this second activity still occupies a less important role than the first. It goes without saying that nowadays the conviction that Public Humanities "meant the reception of humanities by anyone but academics" (Schroeder 2021, 9) is seen completely outdated and as part of an atavistic heritage that culminated with the publication of On the Uses of the Humanities: Vision and Application (1984) by a group of researchers from the Hastings Center in New York. Conversely, today the oppositional nature of the dyad 'public' and 'academic' appears to have been replaced by the image of a close continuity and profitable interaction between the two poles, as it can be seen from the case studies presented in this volume and in Smulyan (2021). This leads to the conclusion that Public Humanities takes place on and off university campuses and involves the participation of scholars and students as well as local communities and citizens.

Given these premises, it is not difficult, along these lines, to take a further step to identify the most important outcomes in the direction we are interested in. As Smulyan states (but see also Burton, Fisher 2021), Public Humanities ultimately defines itself as

a way to create new knowledge, just as does the best of more traditional scholarship. (Smulyan 2021, 2)

The decision to entitle the volume Knowledgescape should be interpreted in this light, in order to underline the osmotic exchange (rather than the unidirectional outflow) of knowledge between the academic field and the social context. In this regard, the suffix -scape is to be understood as an explicit allusion to the model of global cultural flow developed by Appadurai (1990; 1996). The American anthropologist, starting from the assumption that the current complexity of 
the global economy is due to the presence of some fundamental disjunctures in the triad economy-culture-politics, proposes

that an elementary framework for exploring such disjunctures is to look at the relationship between five dimensions of global cultural flow which can be termed: (a) ethnoscapes; (b) mediascapes; (c) technoscapes; (d) finanscapes; and (e) ideoscapes. (Appadurai 1990, 296)

In the formulation theorised by Appadurai, the choice of the suffix -scape was suggested by two main reasons, which also lend themselves to describing the reality deployed in this volume. Firstly, it has the merit of representing effectively the fluid and irregular form of the landscapes presented by Appadurai, which is basically common to that of the Public Humanities. These consonances are further reinforced by the fact that the relationships between the landscapes, like those that have marked the history of Public Humanities in the past decades, are qualified as a kind of

deeply perspectival constructs, inflected very much by the historical, linguistic and political situatedness of different sorts of actors. (296)

In this sense, 'knowledgscape' refers not only to the flow of knowledge that is conveyed from academic and cultural institutions at large to communities (and vice versa), but also to the underlying complexity of such exchanges, which are characterised by their heterogeneous and chaotic nature, and influenced by manifold cultural, social and political factors (Rantanen 2006, 12; Jacobson 2021, 167).

Re-examined in this way, the discourse on the Public Humanities turns into an attempt to re-establish bridges between the domains of specialised knowledge and the audiences, by developing a variety of channels, models and formats that allow forms of knowledge to 'matter' in society. In this way, the humanities appear reinvigorated by public-facing practices and the crisis that surrounds them is transformed into an opportunity for renewal "to extend or remap fields of enquiry and knowledge" and "to reposition them with respect to contemporary society" (Schnapp 2014, 6). This is, in essence, the starting point of Jeffrey Schnapp's keynote lecture (Schnapp, unpublished) dedicated to the ways of transferring knowledge in contexts that have an impact outside the academic sphere, that is, how to make knowledge 'actionable'. In his paper, Schnapp stresses that the problem of transferring expertise to a non-expert audience is not so much a question of disseminating knowledge but rather of "reimagin[ing], reinvent[ing] and redesign[ing] knowledge forms" (Schnapp, unpublished). In other words, it is a matter of knowledge design, as this implies rethinking not only contents, but also meth- 
ods, forms and genres that produce humanistic knowledge (Schnapp $2014,5)$. In short, it is critical design practice that makes it possible to break down the obstacles that make specific domains of knowledge inaccessible or invisible to the general audience. Hence the need to rethink training moments inside and outside the university in the direction of paths that are able to unite and reconcile practical and theoretical instances.

In conclusion, the itinerary unfolded in the following essays shows once again, if ever there was a need, that raw data are not enough: in order to acquire value, they must be edited, shaped and critically interpreted (Burdick et al. 2014, 71-7, 81-4). This is precisely one of the tasks of humanists which cannot be demanded by the machines but only explored with their help. Hence the usefulness of thinking about a new commitment in terms of representation and visualisation of data with the aim of presenting them to a broad, general audience, coinciding with communities in the broad sense (Schnapp 2014, 12-13). This task should not be separated from an experimental approach which, by fostering the creation of cross-media and multimedia contents, translates data into innovative forms (storytelling, spatialisation) that allow to identify new relations intelligible to a wide audience. This could take place especially in hybrid environments, laboratories inside or outside academic institutions (such as the Civic Design Data Lab at MIT) which, by qualifying themselves as spaces devoted both to research and to public persuasion and communication, foster critical and creative thinking by affecting the social fabric. After all, this is also (or above all) what is sought from humanities for change.

\section{Bibliography}

Appadurai, A. (1990). "Disjuncture and Difference in the Global Cultural Economy". Theory, Culture \& Society, 7(2-3), 295-310. https://doi. org/10.1177/026327690007002017.

Appadurai, A. (1996). Modernity at Large: Cultural Dimensions of Globalization. Minneapolis (MN); London: University of Minnesota Press.

Burdick, A.; Drucker, J.; Lunenfeld, P.; Presner, T.; Schnapp, J. (2014). Umanistica_digitale. Milano: Mondadori.

Brumfield, B. (2017). "Accidental Editors and the Crowd". Boot, P. et al. (eds), Advances in Digital Scholarly Editing. Papers Presented at the DiXiT Conferences in The Hague, Cologne, and Antwerp. Leiden: Sidestone Press, 69-84.

Burton, K; Fisher, D. (2021). Public Humanities and Publication: A Working Paper. London; Washington D.C.: Routledge; National Humanities Alliance. http://dx.doi.org/10.17613/gpvb-x279.

Cartiere, C. (2008). "Coming in from the Cold: A Public Art History". Cartiere, C; Willis, S. (eds), The Practice of Public Art. New York; London: Routledge, 7-17. 
Cauvin, T. (2018). "The Rise of Public History: An International Perspective". Historia Crítica, 68, 3-26. https://doi.org/10.7440/histcrit68.2018.01.

Cauvin, T. (2021). "New Field, Old Practices: Promises and Challenges of Public History". magazén, 2(1), 13-44, http://doi.org/10.30687/mag/27243923/2021/03/001.

Cooper, D.D. (2014). “Can Civic Engagement Rescue the Humanities?". Cooper D.D. (ed.), Learning in the Plural. Essays on the Humanities and Public Life. East Lansing (MI): Michigan State University Press, 151-165.

Ellison, J. (2013). "Guest Column. The New Public Humanists". PMLA, 128(2), 289-98.

Fischer, F.; Mantoan, D.; Tramelli, B. (2020a). "A New Venture and a Commitment to Disciplinary Fusion in the Domain of Digital and Public Humanities". magazén, 1(1), 7-16.

Fischer, F.; Mantoan, D.; Tramelli, B. (2020b). "By Way of Another Editorial on Fusions in the Digital and Public Humanities". magazén, 1(2), 137-42.

Gorman, M.J. (2020). Idea Colliders: The Future of Science Museums. Cambridge (MA): The MIT Press. MetaLABprojects.

Hastings Center (1984). On the Uses of the Humanities: Vision and Application. A Report from the Hastings Center. Hastings-on-Hudson (NY): Hastings Center.

Heinisch, B. (2020). "Citizen Humanities as a Fusion of Digital and Public Humanities?" magazén, 1(2), 143-80. https://doi.org/10.30687/

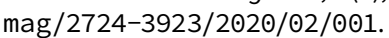

Italia, P. (2020). Editing Duemila. Roma: Salerno Editrice.

Jacobson, M.F. (2021). "Afterword: the 'Doing' of Doing Public Humanities". Smulyan, S. (ed.), Doing Public Humanities. New York; Abingdon (Oxfordshire): Routledge, 165-73.

Johansson, F. (2006). The Medici Effect. What Elephants and Epidemics Can Teach Us About Innovation. Boston (MA): Harvard Business School Press.

Levin, S.A. (2009). The Princeton Guide to Ecology. Princeton (NJ); Oxford: Princeton University Press.

Lubar, S. (2014). "Seven Rules for Public Humanists". Steven Lubar, 5 June. http://stevenlubar.net/public-humanities/seven-rules-forpublic-humanists/.

Mastandrea, P. (a cura di) (2017). Strumenti digitali e collaborativi per le Scienze dell'Antichità. Venezia: Edizioni Ca' Foscari. Antichistica 14. Filologia e letteratura 3. http://doi.org/10.14277/978-88-6969-182-9/ANT_14.

Moshenska, G. (2017). "Introduction: Public Archaeology as Practice and Scholarship where Archaeology Meets the World". Moshenska, G. (ed.), Key Concepts in Public Archaeology. London: UCL Press, 1-13.

Nikitina, S. (2009). "Applied Humanities: Bridging the Gap between Building Theory \& Fostering Citizenship". Liberal Education, 95(1), 36-43. https:// files.eric.ed.gov/fulltext/EJ861150.pdf.

Nussbaum, M. (2010). Not for Profit. Why Democracy Needs the Humanities. Princeton (NJ): Princeton University Press.

Rantanen, T. (2006). "A Man behind Scapes. An Interview with Arjun Appadurai". Global Media and Communication, 2(1), 7-19. https://doi. org/10.1177/1742766506061814.

Ross, C. (2012). "Social Media for Digital Humanities and Community Engagement”. Warwick, C.; Terras M.; Nyhan J. (eds), Digital Humanities in Practice. London: Facet Publishing; UCL Centre for Digital Humanities, 23-45. 
Santagata, M. (2017). Il poeta innamorato. Su Dante, Petrarca e la poesia amorosa medievale. Milano: Guanda.

Schnapp, J.T. (2014). Knowledge Design. Incubating New Knowledge Forms / Genres / Spaces in the Laboratory of the Digital Humanities = Keynote Delivered at the Herrenhausen Conference "(Digital) Humanities Revisited - Challenges and Opportunities in the Digital Age" (Hannover, 5-7 December 2013). Hannover: VolkswagenStiftung.

Schnapp, J.T. (unpublished). "Actionable Knowledge”. Intersections. New Perspectives for Public Humanities $=$ Conference Proceedings (Venice, 3 December 2020).

Schroeder, R. (2017). "What is Public Humanities?". Day of Public Humanities, 20 March. https://dayofph.wordpress.com/what-is-public-humanities/.

Schroeder, R. (2021). “The Rise of the Public Humanists?”. Smulyan, S. (ed.), Doing Public Humanities. New York; Abingdon: Routledge, 5-27.

Siemens, R.; Armstrong, K.; Crompton, C. (2014). A Social Edition of the Devonshire Manuscript (BL MS Add 17,492). Toronto (Ontario); Tempe (AZ): Iter; ACMRS.

Smulyan, S. (ed.) (2021). Doing Public Humanities. New York; Abingdon: Routledge.

Steinberg, E.R. (1974). “Applied Humanities?”. College English, 35(4), 440-50.

Szostak, R.; Gnoli C.; López-Huertas, M. (2016). Interdisciplinary Knowledge Organization. New York: Springer.

Zaccarello, M. (a cura di) (2019). Teoria e forme del testo digitale. Roma: Carocci.

Zinn, H. (2008). "The Making of a Public Intellectual". Mitchell K. (ed.), Practicing Public Scholarship. Experiences and Possibilities Beyond the Academy. Malden (MA); Oxford: Wiley-Blackwell, 138-41. 


\title{
Knowledgescape
}

Insights on Public Humanities

edited by Eugenio Burgio, Franz Fischer, Marco Sartor

\section{Public History e università italiana: esperienze, criticità e prospettive}

Stefano Dall'Aglio

Università Ca' Foscari Venezia, Italia

\begin{abstract}
In recent years Italian Public History has gone through a process that has transformed it from a series of practices to a more institutionalised discipline. The university teaching and research activities in Public History have to deal with the problem of the discipline's recognition in a rigid academic system that is based on pre-determined disciplinary areas and in which unconventional research outcomes are discouraged. In this context, the innovative experience of the Venice Centre for Digital and Public Humanities (VeDPH) at Ca' Foscari University constitutes a new model of interaction between Public History and universities, with a targeted recruitment and the organisation of a broad range of activities in the field.
\end{abstract}

Keywords Public History. Italy. Venice. University. Research. Teaching. Discipline.

Sommario 1 La Public History: da pratica a disciplina. - 2 Il riconoscimento della Public History. - 3 L'esperienza del Venice Centre for Digital and Public Humanities. 


\section{La Public History: da pratica a disciplina ${ }^{1}$}

Come docente di Public History, talvolta non posso fare a meno di incappare in una delle convinzioni più diffuse tra chi ne ha soltanto una conoscenza superficiale: quella che 'sia sempre stata fatta'. In fin dei conti, chi non si è mai imbattuto in un documentario di storia, non ha mai guardato un film storico, o letto un romanzo storico? È fuori di dubbio che la Public History sia stata praticata inconsapevolmente in passato, ed è anche opportuno precisare che non ne esiste una definizione universalmente condivisa, e nondimeno sarebbe sbagliato pensare che essa sia soltanto un nome nuovo (e più trendy) per una vecchia pratica. Come replicare a chi fatica a cogliere la carica innovativa dell'attuale Public History? Proviamo a ipotizzare alcune strade.

1. Innanzitutto la Public History non è soltanto divulgazione della storia, ma anche interazione con il pubblico in ogni fase della ricerca storica, dalla scelta delle domande alla raccolta delle fonti, all'elaborazione della metodologia da adottare. E inoltre la Public History include anche la storia applicata, in cui il pubblico svolge il ruolo del committente e stabilisce il tema stesso della ricerca o (secondo una concezione più nordamericana che europea) in cui la metodologia e la conoscenza della storia vengono impiegate per affrontare le questioni poste dal presente.

2. La seconda possibile risposta è che la divulgazione storica è cambiata, e molto, rispetto al passato. Se un tempo esisteva ben poco rispetto a film, romanzi storici e riviste divulgative, ora lo spettro delle attività di disseminazione della ricerca storica si è ampliato a dismisura. Molta parte di questa profonda trasformazione è legata al digitale, che ha messo in campo una gamma infinita di tecnologie e strumenti per portare avanti e presentare un lavoro di storia con metodologie innovative e raggiungendo pubblici vastissimi, grazie anche alla straordinaria forza di propagazione di internet. E anche lasciando da parte il digitale e il web esistono oggi attività un tempo sconosciute o quasi, dalla living history, agli urban games storici ai musei interattivi.

3. La terza strada per replicare a chi ritiene che la Public History sia sempre esistita, quella più rilevante agli effetti del presente contributo, è che un conto è una pratica e un altro conto è una disciplina, come già notato per la Public History internazionale (Cauvin 2018,

1 Questo contributo nasce da un invito alla giornata internazionale di studi Intersections. New Perspectives for Public Humanities con il quale mi era stato chiesto di presentare l'esperienza del VeDPH, di cui faccio parte, collocandola nel più ampio contesto della Public History italiana. Desidero ringraziare Cecilia Dau Novelli per aver riletto e commentato l'articolo. Ovviamente la responsabilità per le opinioni espresse e per eventuali imprecisioni è soltanto mia. 
5-6). Se è vero, infatti, che già Alexandre Dumas scriveva romanzi storici, è altrettanto vero che l'attività di un romanziere dell'Ottocento non si collocava in un movimento globale fatto di individui con interessi comuni e obiettivi e metodologie condivise. Ė un discorso che non vale solo per la divulgazione, ma anche per le attività partecipative, nelle quali il pubblico è coinvolto nella produzione della ricerca storica e non solo nella fruizione del suo prodotto finale. Inoltre, un tempo non mancavano soltanto il senso di appartenenza e la consapevolezza propri di coloro che si riconoscono in una disciplina, ma anche qualsiasi tipo di istituzionalizzazione e organizzazione generale di un fenomeno che fino a pochi anni fa, almeno a livello italiano, era anche difficile da individuare e inquadrare. Pur nella mancanza di una definizione univoca, l'attuale Public History italiana è invece fatta di un'associazione nazionale, di un manifesto che ne definisce caratteristiche e obiettivi, di pubblicazioni, di conferenze e di corsi universitari. Come tale, dunque, ha iniziato ad acquisire la consapevolezza e la struttura propria di una disciplina, pur nell'anomalia e nel carattere di novità che ancora la contraddistinguono e nel permanere di alcune comprensibili perplessità (Botti 2017, 105). Ad oggi possiamo senz'altro dire che la Public History non è più quella che nel 'lontano' 2011 Serge Noiret, attuale presidente dell'Associazione Italiana di Public History, aveva definito una 'disciplina fantasma' (Noiret 2011). ${ }^{2}$

Riconoscere alla Public History lo status di disciplina universitaria, tuttavia, fa sorgere degli interrogativi che ne toccano la più intima natura. Com'è possibile che una materia nata in antitesi alle università diventi di casa proprio all'interno di esse? Le tradizionali definizioni di Public History, infatti, parlano di storia «outside of academia» (Kelley 1978, 16) o «beyond the classroom» (Sayer 2015, 1-2) per marcare la distanza non solo dalla didattica ma anche e soprattutto dalla torre d'avorio dei docenti autoreferenziali che dialogano tra di loro tramite convegni e pubblicazioni specialistiche ignorando e tagliando fuori il mondo circostante. Le risposte possono essere molteplici.

Una prima possibile replica è che non c'è niente di strano nell'insegnare all'interno delle aule universitarie una materia che poi, una volta appresa, verrà messa in pratica altrove. Lo sa bene, ad esempio, un architetto, che costruisce edifici in giro per il mondo ma che proprio nelle aule universitarie ha imparato come farlo. D'altra parte, è innegabile che l'accademia resti il luogo deputato all'acquisizione dei 'ferri del mestiere' di storico, 'public' o meno che sia (Scanagatta 2017, 317). Un'altra possibile risposta è che anche un docente universitario, pur interagendo quotidianamente con studenti e col- 
leghi, può instaurare un dialogo con soggetti esterni all'accademia per portare avanti i suoi progetti di ricerca. È il caso dello studioso che collabora con una comunità locale per ricostruirne la storia con metodi di storia partecipativa, shared authority o storia orale, o per comunicare i risultati del suo lavoro. Credo che approcci di questo tipo vadano accolti con favore come un arricchimento di una comunità accademica tradizionalmente troppo avvolta su sé stessa, e non guardati con sospetto e sufficienza come se andassero necessariamente di pari passo con un ridimensionamento della qualità scientifica del lavoro.

Nel 2018 il sopracitato Manifesto della Public History italiana ha efficacemente sciolto l'equivoco sull'apparente contrapposizione tra Public History e università spiegando che, se da una parte la disciplina coincide con la storia «all'esterno degli ambienti accademici», dall'altra è anche «un'area di ricerca e di insegnamento universitario finalizzata alla formazione dei public historian» (AIPH 2018, 2; enfasi nell'originale). Bene fa Mirco Carrattieri ad ammonire sul pericolo che la disciplina venga assorbita dalle università perdendo quindi parte della sua natura originaria (Carrattieri 2019, 120). Già quindici anni fa un public historian statunitense esterno all'università aveva suonato un campanello d'allarme: la professionalizzazione accademica consolida la disciplina ma al tempo stesso, per sua natura, ne irrigidisce i confini, limita i margini di creatività al di fuori da schemi predeterminati, e taglia fuori coloro che non soddisfano specifici requisiti (Filene 2006). La consapevolezza dei pericoli, tuttavia, non deve indurre a rifiutare qualsiasi tipo di interazione, arrivando a escludere non solo la possibilità di una formazione strutturata dei public historians, ma anche quella che un accademico possa collaborare con un pubblico diverso da colleghi e studenti.

La questione della formazione dei public historians nelle università a sua volta apre la strada a un delicato interrogativo. Chi forma i docenti di Public History? Recentemente Chiara Ottaviano si è domandata se l'università fosse adeguatamente attrezzata (Ottaviano 2017, 53). Una domanda non banale se si considera l'anomalia di una materia che attualmente viene insegnata quasi sempre da chi non l'ha mai studiata, se non da autodidatta. Un paradosso al momento inevitabile, sia perché il primo insegnamento italiano in materia (il Master di Public History dell'Università di Modena e Reggio Emilia) è nato soltanto nel 2015 (Noiret 2015) sia perché i ferrei meccanismi di reclutamento delle università italiane rispondono a criteri ancora difficilmente compatibili con i variegati percorsi formativi della Public History. 


\section{Il riconoscimento della Public History}

Il complesso tema della formazione dei docenti esula dagli obiettivi del presente contributo, con il quale invece si intende adottare una prospettiva più ampia, che investe il problema più generale del riconoscimento della Public History nell'università italiana. Un riconoscimento che a mio giudizio dovrebbe essere attuato almeno in quattro modi distinti.

1. Innanzitutto sarebbe auspicabile un riconoscimento non ufficiale: per troppo tempo gli storici impegnati in lavori di divulgazione o in collaborazioni con il pubblico sono stati guardati con snobismo dagli storici tradizionali, come se il loro lavoro fosse reso meno nobile dall'interazione con una comunità locale o dalla realizzazione di un fumetto o di un prodotto radiofonico destinati al grande pubblico. Un ulteriore pregiudizio riguarda poi la Public History in quanto tale, talvolta denigrata anche da storici che in realtà praticano correntemente alcune forme di divulgazione ad essa riconducibili (Noiret 2017, 14-15). Le cose sono andate cambiando negli ultimi due decenni, ma la questione è tutt'altro che chiusa: prodotti come documentari, webdocs o podcast sono ancora considerati di serie B rispetto a una pubblicazione scientifica, indipendentemente dalla loro qualità.

2. Questo ci porta inevitabilmente al secondo nodo cruciale per il riconoscimento della Public History: il riconoscimento ufficiale dei prodotti della ricerca. Al momento per gli storici la VQR (Valutazione della Qualità della Ricerca) gestita dall'ANVUR (Agenzia Nazionale di Valutazione del Sistema Universitario della Ricerca) - il censimento ufficiale del lavoro di ricerca svolto nelle università italiane - si basa quasi esclusivamente sulle pubblicazioni scientifiche (ANVUR 2020 , art. 5, c. 2). ${ }^{3}$ Dal punto di vista di questa valutazione - decisiva per la ripartizione dei fondi successivamente erogati dal MIUR alle varie università - gli altri tipi di prodotto sono pressoché irrilevanti. Si tratta, com'è evidente, di condizioni che scoraggiano fortemente uno storico o una storica dal trasformare la propria ricerca in un'app o una graphic novel, indipendentemente dal fatto che queste possano anche essere prodotti di altissima qualità e possano raggiungere un pubblico molto vasto ed eterogeneo altrimenti difficile da intercettare. È vero che tra i possibili prodotti della ricerca elencati dall'ANVUR figurano anche le mostre e i materiali audiovisivi, ma c'è da domandarsi quali tipologie di prodotti e di studiosi avessero in mente gli estensori del decreto, e come potrebbe essere valutato (se mai fosse presentato) il caso di un video di animazione di argomento storico fatto circolare su YouTube.

3 Altri tipi di prodotti della ricerca contemplati dall'ANVUR non sono applicabili al lavoro degli storici, come progetti architettonici e test psicologici. 
Esiste - si dirà - la Terza Missione (ANVUR 2020, art. 9). Questa però, all'interno della VQR, costituisce una categoria separata da quella relativa ai prodotti della ricerca (ANVUR 2020, artt. 5-8), e la sua stessa denominazione fa riferimento al suo essere una sfera 'altra' rispetto a formazione e ricerca. Ma se prodotti come quelli sopracitati - dal webdoc al podcast - sono il frutto di un lavoro di ricerca (lo stesso decreto ANVUR parla ripetutamente di «legame con i risultati della ricerca scientifica») non è chiaro per quale motivo non possano essere considerati prodotti della ricerca. È evidente che, almeno per quanto attiene alle forme di comunicazione dei risultati del lavoro, il modello che emerge da questo schema ci riconsegna fatalmente l'ingiallita immagine dello studioso rinchiuso nella torre d'avorio, perché i prodotti della ricerca sono soltanto quelli che si rivolgono a un pubblico di pari: accademici, studiosi, esperti della materia. Se il pubblico è invece composto da non specialisti, il lavoro in questione - fosse anche un libro di alta divulgazione frutto di anni di meticolosa ricerca - finisce fatalmente per essere catalogato sotto una voce diversa, il cui status è chiaramente meno nobile come molto inferiore è la sua incidenza sulla valutazione accademica ufficiale.

Infatti, attualmente la valutazione della Terza Missione concorre soltanto in minima parte alla ripartizione della quota premiale del FFO (Fondo di Finanziamento Ordinario delle università italiane), almeno i 3/5 della quale vanno assegnati per legge in base ai risultati della VQR. ${ }^{4}$ Allo stato attuale ogni dipartimento può proporre al massimo due casi di studio, ma le università dovranno sceglierne un numero pari alla metà del numero dei dipartimenti (ANVUR 2020, art. 9, cc. 1-2). Un'ipotetica università di medie dimensioni con dieci dipartimenti, ad esempio, pur avendo migliaia di docenti potrebbe presentare soltanto cinque miseri casi di studio, il che rende quasi impossibile che dei prodotti di storia, e più in generale delle humanities, escano vincitori dall'impari confronto con quelli elaborati da medici, biotecnologi, giuristi, ingegneri ed economisti.

Per finire, va precisato che la Terza Missione non coincide con il Public Engagement, come molti in ambiente umanistico credono. Il Public Engagement è soltanto una di dieci aree che includono diversi tipi di attività, dal conseguimento di brevetti alla sperimentazione clinica (ANVUR 2020, art. 9, c. 3), secondo un paradigma in cui la produzione di cultura sembra essere progressivamente subordinata alla produzione di ricavi. Il concetto di Terza Missione tende così a essere appiattito su quello più discutibile di 'impatto' prodotto sulla società, sul pericoloso modello dell'impact dell'accademia britannica (De Groot 2018; Smith et al. 2020). La progressiva limitazione

4 Legge 9 agosto 2013, nr. 98, all. 2, art. 60, comma 1. https://www.gazzettaufficiale.it/eli/id/2013/08/20/13G00140/sg. 
alle «attività di Terza Missione il cui impatto sia verificabile» (ANVUR 2020, art. 9, c. 1) è d'altra parte certificata dall'avanzare di una nuova denominazione, quella di «Terza Missione e Impatto Sociale» (ANVUR 2018). Una concezione di questo tipo, tuttavia, ci allontana ulteriormente dall'idea di Public Engagement, come anche da quella di Knowledge Transfer. Infatti, se la comunicazione della ricerca storica a un pubblico non specialistico a mio avviso rientra a pieno titolo nei compiti che lo storico dovrebbe svolgere, l'idea che gli studiosi vadano premiati nella misura in cui producono dei cambiamenti concreti, immediati e misurabili nella società contemporanea è a dir poco problematica. Una valutazione di questo tipo penalizza inequivocabilmente le discipline umanistiche e tutti coloro che producono cultura fine a sé stessa, un bene non quantificabile e i cui benefici sul breve periodo sono spesso impercettibili.

Intendiamoci: non si tratta di un problema soltanto italiano. Perfino negli Stati Uniti, dove il dibattito sull'argomento è iniziato con almeno trent'anni di anticipo, è già da tempo stato rilevato come l'integrazione della Public History nell'accademia abbia avuto l'effetto di scoraggiare le attività di Public Engagement, considerate «not very serious» non solo per un docente strutturato ma anche per un aspirante tale. In un sistema in cui le progressioni di carriera si basano quasi esclusivamente sulle pubblicazioni scientifiche, il solco tra accademici e practitioners esterni all'università ha finito per essere sempre più profondo (Filene 2006, 14).

3. Il terzo punto, di vitale importanza, riguarda il riconoscimento ufficiale della Public History come disciplina in un sistema universitario caratterizzato da una divisione in settori scientifico-disciplinari che di fatto inibisce l'interdisciplinarietà e irrigidisce le carriere. L'Italia uno dei pochi paesi in cui non può essere aperta una procedura per il reclutamento di un docente di Public History. Le procedure concorsuali devono infatti essere ricondotte ai singoli settori scientifico-disciplinari, e se si bandisce un concorso per un posto di Storia Contemporanea (settore M-STO/04), gli storici antichi, medievali e moderni rimangono inevitabilmente tagliati fuori. E le limitazioni derivanti dall'appartenenza al settore scientifico-disciplinare non riguardano soltanto il reclutamento, ma si estendono ad una vasta gamma di ambiti, dalla didattica alla progressione di carriera, alla valutazione della ricerca (Pascuzzi 2014; De Paola et al. 2015). Come se ne esce? La via d'uscita più semplice sarebbe, se non l'abolizione in toto dei settori scientifico-disciplinari (come, ad esempio, nel Regno Unito), una loro profonda rimodulazione, magari traendo ispirazione dalle molto più larghe macroaree di ricerca previste del- 
la Comunità Europea. ${ }^{5}$ In alternativa, si potrebbe pensare alla creazione di un settore specifico di Public History, transdisciplinare e privo di barriere cronologiche. Tuttavia, la definizione di cosa rientra o meno nel settore sarebbe problematica, e il rischio sarebbe quello di uscire da una gabbia per rinchiudersi in un'altra, perché un eventuale lavoro 'non public' del nostro storico immaginario ricadrebbe fuori settore con tutte le conseguenze del caso.

4. E siamo arrivati alla quarta e ultima delle strade che l'università italiana dovrebbe percorrere per il riconoscimento della Public History. Per quanto pleonastico, va rimarcato che la materia non sarà integrata nell'accademia italiana (che, beninteso, non vuol dire negare o ridimensionare la sua dimensione extra-universitaria) senza che all'interno di essa ci sia un'adeguata offerta didattica. Un'esigenza irrinunciabile recentemente sottolineata anche da Serge Noiret: «abbiamo bisogno [...] che i programmi universitari riconoscano ufficialmente che la Public History è diventata parte del curriculum umanistico» (Noiret 2019b). Beninteso: non tutti gli studenti che seguono un singolo corso di Public History all'università diventeranno public historians, e forse nessuno. Sostenere un singolo esame di diritto o di economia non fa di un laureato in Scienze Politiche un giurista o un economista. Però è bene che gli studenti sappiano di cosa si tratta, come puntualizzava già nel 2011 l'allora presidente dell'American Historical Association Anthony Grafton, auspicando che sempre più università offrissero un assaggio di Public History ai loro studenti prima che questi decidessero cosa fare nella vita (Grafton 2011). Tra l'altro in alcuni contesti il dibattito sull'importanza dell'avviamento alla Public History non si limita più alle aule universitarie ma ormai abbraccia anche quelle scolastiche (Demantowsky 2018).

La materia, tuttavia, è ancora del tutto assente dall'orizzonte didattico della maggior parte delle università italiane. Pur volendo accogliere l'interpretazione più estensiva (contando anche i master di comunicazione storica o i dottorati in storia che abbiano la Public History nella declaratoria) in ben 81 istituzioni universitarie su 97 non c'è traccia di 'storia pubblica'. ${ }^{6}$ E tuttavia la situazione è in piena evoluzione. Infatti, se prima del 2015 (anno della nascita del citato Master di Modena e Reggio Emilia) la disciplina era inesistente su scala nazionale, adesso il panorama è molto più ricco e articolato, con insegnamenti nei corsi di laurea, a livello di master post-laurea, e anche di dottorato. Se ancora nell'estate del 2018 a livello pre-laurea

5 Billari, F.; Verona, G. (2020). «Una nuova organizzazione per ricerca e università». Corriere della Sera, 2 novembre. https://www.corriere.it/editoriali/20_novembre_01/nuova-organizzazioneper-ricerca-universita-5642f452-1c7b-11eb-a718cfe'9e36fab58.shtml.

6 Il numero complessivo delle istituzioni universitarie è ricavato dal sito del MIUR (MIUR 2020). 
esisteva soltanto un corso di insegnamento universitario di Digital Public History all'Università di Salerno (Carrattieri 2019, 107), ora, all'inizio del 2021, almeno nove corsi singoli contano nella loro denominazione l'espressione 'Public History' o 'storia pubblica', in molti casi assurta a disciplina autonoma anche senza il sostegno della rassicurante stampella digitale. ${ }^{7}$ Ai corsi d'insegnamento si aggiungono due programmi di Master (uno di primo e uno di secondo livello) e altri di dottorato, a dimostrazione di una crescita che con tutta probabilità continuerà nei prossimi anni. Indubbiamente anche in Italia vale quanto osservato a livello internazionale: l'insegnamento della Public History è in crescita, in controtendenza con l'insegnamento della storia tradizionale (Parsons 2012; Ress 2019). D'altra parte, è innegabile che l'ascesa della Public History sia legata anche alla cosiddetta 'crisi della storia', in termini tanto di prestigio quanto di numero di docenti e studenti (Ottaviano 2017; Zannini 2017; Ridolfi 2017; Savelli 2019, 19-21), che si traduce nell'esigenza di insegnare e praticare la storia in un modo diverso da quello tradizionale.

L'Italia, tra l'altro, sta facendo bene anche in ambito europeo, lasciando da parte il caso del Regno Unito, dove un Master di Public History ha fatto la sua comparsa già nel lontano 1996 (Ruskin College, Oxford) e dove la tradizione della disciplina ha radici molto più profonde che nel resto d'Europa (Cauvin 2018, 9). A livello di Europa continentale, il nostro paese è uno di quelli in cui la didattica di Public History è più presente. Secondo il censimento del National Council on Public History, la più grande e antica associazione del settore a livello mondiale, l'Italia è con Germania e Francia il paese con il maggior numero di corsi di laurea o master (NCPH 2020). ${ }^{8}$ Non è, tutto sommato, una sorpresa, se consideriamo che il nostro paese ha sviluppato una sua via alla Public History prima di molti altri, forte di tradizioni precedenti proprie sia della ricerca storica - dalla storia orale alla microstoria - sia della divulgazione e dell'intrattenimento - dal romanzo storico alla rievocazione al turismo storico (Bistarelli 2019; Carrattieri 2019). Prima in Europa ad avere una sua associazione nazionale della disciplina (Cauvin 2018, 20; Noiret 2019a), l'Italia è stato anche il paese che ha presentato più proposte di panels (escludendo Germania e USA, il paese organizzatore e la patria della Public History) all'ultima conferenza dell'International Federation for Public History (Marsillo 2019).

7 Le università che al momento hanno corsi di Public History (Master esclusi) sono Cagliari, Campania Vanvitelli, Firenze, Macerata, Modena e Reggio Emilia, Pisa, Salerno, Trieste e Ca' Foscari Venezia (Tucci 2021).

8 Il dato si basa sulla somma di undergraduate e graduate programmes per un totale di 236 corsi. 


\section{L'esperienza del Venice Centre for Digital and Public Humanities}

In questo contesto generale di crescita della Public History italiana, l'Università Ca' Foscari di Venezia ha iniziato recentemente a recitare un ruolo di primo piano. Il 5 giugno 2019 all'interno dell'università è stato inaugurato il VeDPH (Venice Centre for Digital and Public Humanities). ${ }^{9}$ La nascita del Centro è stata resa possibile da un consistente finanziamento erogato dal MIUR per un Progetto di Eccellenza del Dipartimento di Studi Umanistici, presentato con notevole lungimiranza già nel 2017, quando la Public History era ancora quasi del tutto assente dal panorama universitario dello stivale.

Il VeDPH non abbraccia solo la storia ma al suo interno la Public History riveste un ruolo fondamentale sotto tutti i punti di vista, dalla ricerca alla didattica agli eventi. Per quanto riguarda l'insegnamento, va detto che grazie al VeDPH attualmente $\mathrm{Ca}^{\prime}$ Foscari è l'unica università italiana che offre due diversi corsi di Public History insegnati in due diverse lingue (inglese e italiano) con due diverse modalità (corso tradizionale e laboratorio) in due diversi corsi di laurea magistrale (Digital and Public Humanities e Storia dal Medioevo all'Età Moderna). Oltre a questo, il VeDPH è un caso più unico che raro di hub permanente che si occupa (anche) di Public History con un programma di reclutamento e di attività a trecentosessanta gradi. Il reclutamento include posizioni di Public History a tutti i livelli, dal docente strutturato al visiting professor, dall'assegnista di ricerca (research fellow) al dottorando. Unico caso di mia conoscenza in Italia, è stata attuata una procedura di reclutamento per un Ricercatore a Tempo Determinato di tipo B orientata specificatamente ad un profilo di Digital e Public History, pur nel rispetto della angusta cornice normativa imposta dai citati settori scientifico-disciplinari. Le attività del Centro, nelle quali la Public History svolge un ruolo di primo piano, spaziano dai seminari ai workshop, dalla summer school a un nuovo corso di laurea magistrale, fino a una nuova rivista scientifica, in cui la vocazione di apertura al pubblico è confermata dalla modalità di pubblicazione in open access.

Alle iniziative del VeDPH hanno preso parte diversi specialisti della Public History internazionale, da Tanya Evans (Macquarie University, Sydney) a Mirco Carattieri (Istituto Nazionale 'Ferruccio Parri' di Milano), da Frédéric Clavert ( $\mathrm{C}^{2} \mathrm{DH}$ - Université de Luxembourg) a Sarah May (Swansea University). A questo si aggiungono gli articoli nella nuova rivista del Centro - magazén | International Journal for Digital and Public Humanities ${ }^{10}$ - a firma di alcuni tra i maggio-

9 https://www.unive.it/vedph.

10 https://edizionicafoscari.unive.it/it/edizioni4/riviste/magazen/. 
ri esperti del settore, da Enrica Salvatori (Università di Pisa) al presidente dell'International Federation for Public History Thomas Cauvin ( $\mathrm{C}^{2} \mathrm{DH}$ - Université de Luxembourg).

Molti sono anche i progetti di Public History portati avanti dai ricercatori del VeDPH, che includono un webdoc sulla rappresentazione televisiva delle leggi razziali (Leonardo Campus), ${ }^{11}$ un video di animazione sull'origine di Venezia (Elisa Corrò, insieme a un team diretto da Sauro Gelichi) e uno studio dei tweets per la comprensione della memoria collettiva del COVID-19 (Deborah Paci, insieme a Frédéric Clavert). Altre ricerche sono condotte dai dottorandi del Centro, come quella sul concetto di barbaro nel dibattito mediatico e politico contemporaneo e lo studio dei graffiti delle carceri inquisitoriali in un'ottica 'public' che include comunicazione multimediale, storytelling e percorsi di inclusione sociale. Completano il quadro i progetti finanziati dal VeDPH e portati avanti da storici del Dipartimento di Studi Umanistici di Ca' Foscari, come gli incontri su Roma antica e Public History (Francesca Rohr) e l'Archivio di Storia Orale (Alessandro Casellato). Tutto questo - giova sottolinearlo - in un solo anno e mezzo di vita, più della metà del quale funestato dalle restrizioni legate all'emergenza Coronavirus.

Per quanto riguarda l'apertura verso l'esterno, vale la pena di sottolineare che il VeDPH è attivamente coinvolto nell'organizzazione della quarta conferenza nazionale dell'Associazione Italiana di $\mathrm{Pu}$ blic History (AIPH), inizialmente programmata per il 2020 a Venezia e Mestre, e ora rinviata al maggio 2022. Il Centro di Ca' Foscari è anche inserito in due diversi network di Public History, ancora allo stato embrionale ma che si avviano a costituire due solide reti per l'interazione tra le università che si occupano della disciplina. A livello italiano, il neonato CISPH (Centro Interuniversitario per la Ricerca e lo Sviluppo sulla Public History), che si propone di sviluppare iniziative comuni e di promuovere ricerche e altre attività; a livello internazionale, un network di università europee promosso da Thomas Cauvin nell'ambito del progetto PHACS (Public History as the New Citizen Science of the Past) e finalizzato all'interazione didattica e alla condivisione di progetti degli studenti.

Il Centro di Ca' Foscari intende offrire un nuovo modello di integrazione della Public History nell'università italiana, basato su una ricca offerta didattica, una pluralità di eventi aperti al pubblico, una varietà di approcci e metodologie di ricerca, e una spiccata apertura internazionale. Non sta a noi dire se questo esperimento può costituire un prototipo ripetibile altrove. Con le specificità che attengono ai singoli casi, in un futuro in cui la storia si tingerà sempre più di 'public' ogni università potrà valutare quali passi compiere e quali 
strategie adottare, anche in riferimento all'aspetto, cruciale, di procedure di reclutamento espressamente orientate verso un certo tipo di concezione della storia.

Certo è che il Centro veneziano si colloca in un contesto più generale, un microcosmo composito fatto di altre esperienze incentrate (anche) sulla Public History e avviate anche prima di quella cafoscarina, dal Laboratorio di Public History dell'Università di Cagliari al Laboratorio di Umanistica Digitale dell'Università di Pisa. Queste e altre esperienze, pur nella loro diversità, nel loro complesso riflettono l'interesse per una disciplina che sta crescendo a livello nazionale, oltre che internazionale. Molte altre università italiane si stanno aprendo alla Public History, integrandola nella loro didattica o promuovendola con iniziative di altro genere che ne condividono le finalità e ne favoriscono la diffusione. Ė importante, come detto, che la Public History non si riduca a disciplina puramente universitaria e l'originaria componente di storia 'outside the academia' non vada né persa né ridimensionata. Ma al tempo stesso non credo si possa prescindere dalla spinta propulsiva che dall'interno dell'accademia si può dare verso l'esterno, ponendo le basi perché nelle aule, non senza auspicabili contaminazioni con il mondo lavorativo sotto forma di stage o tirocini, si formi una nuova generazione di public historians in grado di trovare una collocazione in altri contesti. Non si tratta di una sfida semplice da vincere, ma insegnare ai giovani a guardare la storia con occhi diversi può essere senz'altro un buon inizio.

\section{Bibliografia}

AIPH (Associazione Italiana di Public History) (2018). «Manifesto della Public History italiana». 3 settembre. https://aiph.hypotheses.org/3193.

ANVUR (2018). «Linee guida per la compilazione della Scheda Unica Annuale Terza Missione e Impatto Sociale SUA-TM/IS per le Università». 7 novembre. http://www.anvur.it/wp-content/uploads/2018/11/SUA-TM_ Lineeguida.pdf.

ANVUR (2020). «Valutazione della Qualità della Ricerca 2015-2019. Bando». 25 settembre. https://www.anvur.it/wp-content/uploads/2020/०9/ Bando-VQR-2015-19_25-settembre_2020_versione-accessibile.pdf.

Bistarelli, A. (2019). «Il vantaggio dell'arretratezza? Innovazione e tradizione nella via italiana alla public history». Italia Contemporanea, 289, 97-105.

Botti, A. (2017). «La sfida della Public History». Bertella Farnetti, P.; Bertuccelli, L.; Botti, A. (a cura di), Public History. Discussioni e pratiche. Milano; Udine: Mimesis Edizioni, 97-106.

Carrattieri, M. (2019). «Per una public history italiana». Italia Contemporanea, 289, 106-21.

Cauvin, T. (2016). Public History. A Textbook of Practice. New York; London: Routledge. 
Cauvin, T. (2018). «The Rise of Public History: An International Perspective». Historia Crítica, 68, 3-26.

De Groot, J. (2018). «For What it is 'Worth'? Neoliberalism and Public History». Public History Weekly, 6(12). https://public-history-weekly.degruyter.com/6-2018-12/neoliberalism-public-history/.

De Paola, M.; Jappelli, T.; Scoppa, V. (2015). «L'università chiusa nel recinto dei settori». La voce.info, 24 novembre. https://www.lavoce.info/archives/38537/luniversita-chiusa-nel-recinto-dei-settori/.

Demantowsky, M. (ed.) (2018). Public History and School: International Perspectives. Berlin; Boston: De Gruyter.

Filene, B. (2006). «Training Public Historians: Academy and Reality». History News, 61, 13-15.

Grafton, A. (2011). «Historians at Work III: Public History». Perspectives on History, 1 December. https://www.historians.org/publications-anddirectories/perspectives-on-history/december-2011/historians-at-work-iii-public-history.

Kelley, R. (1978). «Public History: Its Origin, Nature, and Prospects». The Public Historian, 1, 16-28.

Marsillo, C. (2019). «Berlin 2020: Off to a Great Start!». International Federation for Public History Blog, 4 November. https://ifph. hypotheses. org/2994.

MIUR (Ministero dell'Istruzione. Ministero dell'Università e della Ricerca) (2020). «Istituzioni universitarie accreditate». https://www.miur.gov. it/istituzioni-universitarie-accreditate.

NCPH (National Council on Public History) (2020). «Guide on Public History Programs». https://ncph.org/program-guide/?fwp_program_ type=public-history-graduate-program\%2Cpublic-historyundergraduate-program.

Noiret, S. (2011). «La Public History: una disciplina fantasma?». Memoria e Ricerca, 37, 9-35.

Noiret, S. (2015). «Italy's First Master's Degree in Public History starts in September 2015». International Federation for Public History Blog, 29 June. https://ifph.hypotheses.org/748.

Noiret, S. (2017). «Introduzione: Per la Public History internazionale, una disciplina globale». Bertella Farnetti, P.; Bertuccelli, L.; Botti, A. (a cura di), Public History. Discussioni e pratiche. Milano; Udine: Mimesis Edizioni, 9-33.

Noiret, S. (2019a). «An Overview of Public History in Italy: No Longer a Field Without a Name». International Public History, 2(1). https://doi. org/10.1515/iph-2019-๑००9.

Noiret, S. (2019b). «Note sulle origini della Public History italiana ed internazionale». Officina della Storia, 21. https://www.officinadellastoria.eu/ it/2020/05/07/note-sulle-origini-della-public-history-italiana-ed-internazionale/.

Ottaviano, C. (2017). "La 'crisi della storia' e la Public History». Rivista dell'Istituto di Storia dell'Europa Mediterranea, 1, 41-56.

Parsons, A. (2012). «Help Wanted: Thoughts on the Recent Boom in Academic Public History Jobs». History@Work-The National Council on Public History Blog, 17 September. https://ncph.org/history-at-work/helpwanted-thoughts-on-the-recent-boom-in-academic-publichistory-jobs/. 
Pascuzzi, G. (2014). «Soldatini e danni collaterali: i settori scientifico-disciplinari». ROARS-Return on Academic Research and School, 18 gennaio. https:// www.roars.it/online/soldatini-e-danni-collaterali-i-settori-scientifico-disciplinari/.

Ravveduto, M. (2017). «Il viaggio della storia: dalla terra ferma all'arcipelago». Bertella Farnetti, P.; Bertuccelli, L.; Botti, A. (a cura di), Public History. Discussioni e pratiche. Milano; Udine: Mimesis Edizioni, 131-46.

Ress, S. (2019). «The Circle of Life: Reinvigorating the Humanities with Undergraduate Public History Curriculum». International Public History, 2(1). htt-

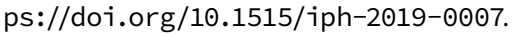

Ridolfi, M. (2017). Verso la Public History. Fare e raccontare storia nel tempo presente. Pisa: Pacini Editore, 9-26.

Savelli, A. (2019). «La Public History dalle origini alla costituzione dell'Associazione Italiana di Public History: movimento o disciplina?». Sapere pedagogico e pratiche educative, 3, 9-22.

Sayer, F. (2015). Public History. A Practical Guide. London et al.: Bloomsbury.

Scannagatta, M. (2017). «Public Historian, tra ricerca e azione creativa». Bertella Farnetti, P.; Bertuccelli, L.; Botti, A. (a cura di), Public History. Discussioni e pratiche. Milano; Udine: Mimesis Edizioni, 315-31.

Smith, K.E.; Bandola-Jill, J.; Meer Nasar; Stewart, E.; Watermeyer, R. (2020). The Impact Agenda: Controversies, Consequences and Challenges. Bristol: Bristol University Press.

Tucci, W. (2021). «Mappa della Public History in Italia». Associazione Italiana di Public History, 21 gennaio. https://aiph.hypotheses.org/9649.

Zannini, A. (2017). «Insegnamento della storia e/è public history». Rivista dell'lstituto di Storia dell'Europa Mediterranea, 1, 119-26. 


\title{
Knowledgescape
}

Insights on Public Humanities

edited by Eugenio Burgio, Franz Fischer, Marco Sartor

\section{Digital Technologies for the Promotion of Cultural History Best Practices in Matera, the European Capital of Culture in 2019}

Francesca Vera Romano

Sapienza Università di Roma, Italia

\begin{abstract}
The relationship between cultural landscape, history and technology is crucial to understand the new tendency of man to carry out actions based on sustainability and on the intertwining of tradition and innovation. Matera, thanks to the current use of technologies for cultural heritage and Smart Agriculture 5G, of which it is one of the experimental cities, is an interesting case study. European Capital of Culture 2019 and a UNESCO World Heritage Site, the City of Stones is characterised by a thousand-year history of archaeological evidence, but also by a material and intangible cultural heritage linked to rural culture and its agricultural landscape, now widely accessible to visitors through digital platforms.
\end{abstract}

Keywords Cultural landscape. Sustainability. Virtual heritage. History. Digital technologies.

Summary 1 Introduction. - 2 A Double Look on the Landscape. - 2.1 The Landscape of Matera. - 2.2 Matera from Magna Graecia to the European Capital of Culture 2019. - 3 A New Dialogue with the Landscape: Sustainability. - 3.1 Smaller Historical Centres. The Case of Matera. - 3.2 THe Promotion of Historical Culture Through New Technologies. 3.3 Sustainable Tourism. -4 Conclusions. 


\section{Introduction}

At present, since globalisation has dissolved both identity and market barriers in favour of the relocation of people and productions, technology and social sciences are called into question regarding the progressive disruption of the relationship between man, landscape and culture and the consequent lack of interest towards community welfare. ${ }^{1}$ Communities' well-being depends on the care of landscapes, that requires both the government and local administrations to develop strategies based on sustainability which now emerge as a crucial issue for the survival of the planet (Lai 2020; Salvarani 2013). The interaction between innovation in technology and cultural heritage, through action based on the recovery of traditional knowledge and practices and their implementation with digital applications, has shown to be a suitable key for sustainability.

As stated in The European Landscape Convention,

Landscape is a portion of land, as perceived by populations, whose character derives from the action of natural and/or human factors and their interrelation. (ELC 2000, 2)

This definition is based on the assumption that some key cultural features deriving from the inextricable historical intertwining between environment and man are expressed through the form and potential of a landscape. This is confirmed by the definition of Cultural Landscape as expressed in the UNESCO Operational Guidelines for the Implementation of the World Heritage Convention.

Cultural landscapes are cultural properties and represent the "combined works of nature and man" as outlined in Article 1 of the Convention. They are illustrative of the evolution of human society and settlement over time, under the influence of the physical constraints and/or opportunities presented by their natural environment and of the following social, economic and cultural forces, both external and internal. (UNESCO 2008, 87)

\section{A Double Look on the Landscape}

In order to provide appropriate analysis and interventions on a landscape, it is necessary to focus on the dual nature of the landscape. In this regard, it may be worth recalling what Marc Augé pointed out

1 The Author would like to thank Francesca Masiero (University College London) for the translation check of this paper. 
when, introducing the concept of anthropological places, he referred to a "concrete and symbolic construction of space" (Augé 2009, 42). For this reason, a landscape is perceived both as external, objective and tangible as it appears to the senses of the observer, and internal, mediated by the cultural look that belongs to the inhabitant that kept it and lived in it.

It is a "principle of meaning for those who inhabit it and a principle of intelligibility for those who observe it" (Augé 2009, 42) because the organisation of space and the constitution of places represent one of the patterns of collective and individual practices; both the collective and individuals symbolise the constituent elements of the shared, particular and individual identity. The way of dealing with space is one of the means of this process of concrete and symbolic construction of space that the French scholar indicates with the expression 'anthropological place'.

The landscape, therefore, is shaped, imagined and described by a social group, and the meaning of places is revealed in the practices which connect them to the collective memory of the community. It is a space in construction, where internal and external complex relations are in continuous re-definition. The identity, both of the landscape and of the community that inhabits it, is therefore not given but historically determined, from time to time, on the basis of the relations between space and the members of its community, but also between space and those who visit it, hang out with it, both really and virtually (De Martino 1959).

The identity of a cultural landscape is therefore constantly evolving, as an open site under relentless construction. In addition, by borrowing the concept of social morphology from French anthropology, a further useful key for the study of the material and immaterial landscape comes to light as it emphasises the complexity of the link between landscapes and population, between space and community, where space is no longer just a centre of resources and social dynamics cannot be separated from symbolic practices, technical representation, and technological space (D’Alessandro et al. 2020).

Anthropological places are of variable scale and are closely related to relational identity and historical perception. A place is, above all, a cultural creation, which is continuous and necessary. The perception of one's own territory is culturally determined. A space, when anthropised and anthropological, can never be neutral. All the systems of symbolic classification that society adopts are projected on it and we can read the same social system through it while the system is constantly being implemented and re-founded. Several elements of the landscape are subject to symbolic manipulation. For instance, the agglomeration of houses, their internal spaces, the districts beyond a town, work spaces and sacred places. All these elements are recollected in a complex system of symbolic references that organises the entire space. 
The organisation of the living space, in many ethnographic contexts, is concretely and metaphorically a reinterpretation of a mythical-ancestral world. As argued by the International Union for Conservation of Nature (IUCN), more attention to the dynamic of conservation of landscapes as 'cultural heritage' should be placed not only to culture itself or nature itself and the relationship that has been established between these two dynamic components, but also to identity values, knowledge and decoding of intangible heritage, according to a more holistic approach. These two elements play an active role because they represent a shared social behaviour and the mechanisms of transmission of knowledge and trans-generation awareness, which are also related to the complex and fascinating world of uses, traditions and rituals, that are key tools to manage a landscape and its culture.

\subsection{The Landscape of Matera}

Thanks to the current use of technologies, the cultural heritage of Matera is now promoted and shared. This makes it one of the most visited destinations with an exponential growth of tourists but significantly impacts on the restructuring of the symbolic space of its landscape and cultural heritage by its inhabitants. Symbolic representation is a central tool of conscious management of the landscape in Matera where the vocation of its land, mainly agricultur$\mathrm{al}$, has generated a traditional rural society in which the concept of neighbourhood, besides a spatial connotation, also had the symbolic connotation of sharing knowledge and practices due to the specific conditions of its land.

The area surrounding Matera has always been affected by severe shortage of water that has determined the need to build a series of ingenious infrastructure such as wells, tanks and divers aimed at achieving efficient management. At the end of the eighteenth century, the city was a perfect model of symbiosis between its anthropic component and a natural ecosystem called 'Sassi', an autonomous organism constituting micro-super-family aggregations consisting of a group of dwellings joined together by the same space, usually equipped with a well and a common oven that reflected and substantiated the concept of neighbourhood in its dual anthropogenic and cultural component. This is tragic but almost mythical and exotic in the eye of the observer.

The subsequent demographic increase determined the beginning of a nefarious process of degradation which led, on the one hand, to the crumbling into multiple units of the delicate biosystem of the surrounding areas and, on the other hand, to the change of the intended use of many environments previously used as cisterns and warehouses in order to obtain new habitable rooms, thus leading not only 
to an architectural evolution of the landscape but also to a cultural evolution that has remote transformation roots (D'Antonio et al. 2019; D’Antonio, Romano 2019).

In his book, the English writer Henry Vollam Morton narrates his visit to Matera in the 1960s, when the city appeared to his eyes as Pompeii, suspended between past and future, once inhabited and then abandoned (Morton 1969). The Sassi were abandoned and the population moved for the most part to new neighbourhoods especially in the rural village of La Martella. There, architects' design was also directed to recreate from an architectural point of view the conditions which reproduced the neighbourhood, the spaces of aggregation, its distinctive rural culture and the identity of the inhabitants of Matera. The project aimed at preserving the cultural landscape identity of the inhabitants of the Sassi which resulted in the construction of buildings that responded to the needs of a rural farming world. These needs were poorly met in the Sassi, and were, for example, the provision of areas where animals could live, which are always near living areas but separated from them.

\subsection{Matera from Magna Graecia to the European Capital of Culture 2019}

The European Capital of Culture 2019 is characterised not only by a thousand-year history of archaeological remains, paintings, frescoes, but also by a material and intangible cultural heritage linked to rural culture and its landscape. Although Matera is located in an inland area, thanks to contacts with the coastal populations of Magna Graecia, primarily Metaponto, it is located in the anthropological landscape of the Mediterranean Sea with its typical productions related to traditional agricultural knowledge, especially wine, oil and wheat.

The spread of viticulture, for example, is one of the most important events in the history of civilisation. It follows the circulation of men and goods and accompanies the settlers in the settlement of new lands. Wine is a typical element of the ancient world and in traditional societies it affects every social dimension. Wine is a 'social fact'. The Aglianico del Vulture is believed to have been introduced by the Greeks in southern Italy between the seventh and the sixth centuries BC. As early as the fifth century BC, Sophocles defined Italy as "Dionysus' favourite country". This shows the link between the Greek cult of the god Dionysus and viticulture in Basilicata. As illustrated by archaeological evidence, many red figure craters were found in the area of Materano which document the use of wine that was accurately mixed with water in the aforementioned craters near the Greeks during the banquets. It also bears witness to the finding of lamps which shows that oil was used to light spaces and that pot- 
tery was used to store foods based on cereals. In classical Greece, as in Magna Graecia, these three products belonged to the universe of the sacred.

In materano, the depiction on pottery of a divinity with branches of olive trees in its hands, Demeter's ear of wheat, the Dionysian procession with satyrs and maedi that relates to the cult of Dionysus and the powerful god of wine, identifies with the Magna Graecia and relates to classical Greece. This goes beyond myths and symbols and becomes a ritual or a practical articulation of daily peasant activities from olive plantation to the cultivation of wine and wheat and their production in materano. The historical, anthropological and archaeological appeal enriches the rural culture linked to traditional cults of the land. The Mediterranean historical identity of the city dates back to the seventh and sixth centuries BC.

The anthropological and productive landscape of the Mediterranean is therefore shaped from Greece to Magna Graecia, up to the area of materano, including cultural elements common to a shared identity which was symbolised by both the community and its individual citizens. The link between past, present and future in the anthropological landscape of materano is a great opportunity to launch the production linked to its tradition once again from an innovative perspective based on sustainability.

\section{A New Dialogue with the Landscape: Sustainability}

One of the objectives of the 1972 UNESCO Convention on Material Cultural Heritage is to protect and enhance representative cultural landscapes. There is a wide variety of landscapes which represents different regions of the world. These complex works are the result of the constructive relationship between man and nature and express the long and intimate relationship between peoples and their natural environment. Some sites, including those with the agricultural or environmental background of the materano reflect specific techniques of land use that can support biological diversity and eco-systemic services.

Due to global meteorological changes, progress, intended as the indiscriminate action of men on the landscape and linked to the industrial age, is now ineffective and requires a different dialogue with landscapes and natural places. These places are renewed 'sacred' elements of human action in the natural order where the concept of sacred as related to the divine is replaced by a concept of sacred intended as respect and care for the landscape which is priceless heritage of mankind.

In this respect, the actions promoted by Matera 2019 stress the need to recover its tradition through innovation and sustainability by emphasizing and strengthening the link between history and 
product landscape via strategic actions which aim at encouraging the spread of an inclusive culture that makes both inhabitants and users of the landscape 'cultural inhabitants'. By contrast, Marc Augé, while talking about spaces and places, identifies in their sharing function the construction of cultural identity that is founded by a link with the past which is the history of the places themselves. As in the past with Magna Graecia, the encounter between peoples and cultures can only take place through the exchange of ideas and techniques that participate in the construction of a shared identity. The Mediterranean space becomes an anthropological meeting place between people and cultures. Therefore, the landscape is not only something to build or protect, but also something to recognise, perceive, listen and describe. The deep link between man, material and immaterial landscape is at the basis of the cultural identity of the Mediterranean community. In traditional, ancient and modern societies, the link with the material landscape, which is mostly agricultural, went through the immaterial landscape, made of moments, times, rituals, rites of passage and mythical worship of natural deities, as already mentioned above and documented by archaeological evidence that bears witness to the adoption of Greek myths in the indigenous culture of Mesogaia (halfway between sea and inland).

The relationship between man and landscape is therefore both mediated by human activity on nature and by cultural activity on the community. These two actions aim to regulate the concrete relationship with nature which is based on the satisfaction of primary needs of individuals and the community. The landscape derives from an evolutionary process and is not an immutable entity. Thanks to this study, we can start from the analysis of the past to foster future actions on the landscape while respecting the peculiarities of the land and the cultural identity of the landscape itself through agricultural practices based on sustainability.

\subsection{Smaller Historical Centres. The Case of Matera}

Smaller historical centres, for their architectural, landscape and anthropic features, are the basis of our historical memory and participate in the construction of our collective identity. They are a widespread presence nationally and find their identity strength in the landscapes and links among regions. Their resources now represent, if properly managed and exploited, a driving force for innovation and sustainability in the process of transformation of the land. Therefore, they must be preserved from degradation and oblivion through actions that avoid depopulation and abandonment. This is happening in some smaller centres through the use of new technologies based on the concept of cultural landscape that promote integrated man- 
agement in the life of the community and cultural and architectural heritage to be enjoyed in harmony with the cultural specificities of the land and its inhabitants.

The European Landscape Convention in 2000 and the Cultural Heritage Code in 2004 affirmed once for all the importance of the landscape, also intended as cultural landscape, in which Title I of Part Three defines the landscape as the expressive territory of identity, whose character derives from the action of natural factors, human resources and their interrelations, which aims to protect the landscape as an expression of cultural values with the aim of safeguarding or recovering them through knowledge, information and training activities, by retraining and using the landscape, and where possible, fostering new, coherent and integrated landscape values in agreement with public administrations.

Already protected in architectural and cultural terms by the Code of Cultural Heritage and thanks to the urban reforms of the 1960s and 1970s, historic centres still require renewed attention. They need a type of safeguarding that does not only include the preservation of the monuments of the past and material heritage, but also protection of customs, traditions and knowledge.

The analysis conducted on the site of Matera, a UNESCO World Heritage Site, and, in particular, on the rural village of La Martella, has shown that 100 historic centres of Italian main cities show this complex picture characterised by different behaviours which is also a consequence of the historical and cultural dynamics that have affected our country (D'Antonio et al. 2020a). Our analysis has shown that the problem of smaller centres is the onslaught of tourism, lack of infrastructure and difficulties in managing landscapes. The European Parliament has already adopted a resolution on this subject.

The 100 historical centres included in this analysis extend across $172 \mathrm{kmq}$, that is $0.6 \%$ of the Italian peninsula, a portion of land which is geographically limited but rich of values if we take into account the cultural and economic value that they represent and their pivotal role for the economy and the image of the country. Matera, a predominantly agricultural town, which historically welcomes complex social relations, has always been a traditional rural society in which the concept of neighbourhood, besides its spatial features, had also the symbolic connotation of sharing knowledge, practices, relationships, and, above all, inclusiveness and sustainability. By building the village of La Martella, the project aimed at preserving the cultural landscape identity of the inhabitants of the Sassi. The design of the study group composed of architects of the Roman School led by Ludovico Quaroni and sociologists, anthropologists and social sciences professionals recreated, from an architectural point of view, the conditions required to reproduce the neighbourhood and the spaces of aggregation typical of the distinctive rural culture and identi- 
ty of the inhabitants of Matera. Faced with the problem of creating a village that could house a part of the citizens displaced by the Sassi of Matera, the pool of scholars understood that the construction of a village that was not perceived as an expression of the community by those who would move to live there could not be felt as an architectural, urban and liveable environment. The delicate phase of displacement from the Sassi to the future rural villages would not have touched only a physical reality but also the most exquisite culture of the rural community of Matera. Therefore, the transfer would not have been free from potential traumas for the parties involved. It was essential to preserve the values of the original community and its cultural peculiarities on which it was founded.

This approach also reflected the new urban trend of the era oriented towards a new way of thinking about cities, which placed social relations at the centre and which, consequently, could not disregard in-depth knowledge of the society that would have lived in it. From this new vision, which resulted from interdisciplinary work, the need to give the new settlement a social and economic structure framed in continuity with the tradition of the community, taking inspiration also from the concept of 'neighbourhood unit', emerged. This unit aimed to reproduce by a calculated composition the peculiar features of the nuclei of the Sassi's houses, which were poor, when not unhealthy, but characterised by a lively community life (Bilò, Vadini, Liman 2016).

Relevant contribution was provided by the anthropology that investigated, in the meantime, the reality of the neighbourhood of the Stones, which, over time, had assumed a function of association and mutual help for the inhabitants in order to reach institutional value and the psycho-social function of moral and material solidarity, but also of transmission of knowledge and practices, as well as beliefs and values (De Martino 1959). In his essay, the anthropologist Tullio Tentori (1976) further investigated how this set of practices and knowledge, or culture in the anthropological sense, is always subject to continuous transformation, due to its internal development and external influences, in terms of 'cultural dynamics'. Therefore, the system 'recreated' by building La Martella would benefit from new sources of agricultural economy based on improved living conditions and greater well-being which is still tied to its original cultural system. For this reasons, urban conditions were created not to upset the system of life of the inhabitants in a traumatic way but to improve it in the wake of its cultural specificity.

With La Martella, urban planning thus became an attempt at social planning based on the awareness of the reality of the natural and cultural landscape on which they intervened. The promotion of La Martella is outlined in detail in the Dossier of Matera as the European Capital of Culture in 2019, in order to make it a centre of cultural production dedicated to the themes of architecture, design and 
urban planning, especially as a permanent design laboratory and, at the same time, to promote a productive vocation based on satellite agriculture and sustainability of production.

\subsection{The Promotion of Historical Culture Through New Technologies}

Matera 2019 moves in the direction of a project of anthropological and cultural enhancement of places, of the material and intangible heritage of the city, a recovery of the relationship man-environment-territory which is based on the harmonisation of these three elements which allows men to live a relationship with their anthropological places, past and history. It intertwines with multiple projects and possibilities of broadening cultural horizons by considering artistic connections between tradition and innovation based on sustainability and enhancement of national culture. This would allow each individual to become a cultural citizen of Matera and the world. Tourists would be surrounded by a symbolic and cultural landscape and would become part of this scenario without losing a sense of belonging to a common destiny. They would also be aware of the need to open culture to sustainability and enhance anthropological landscapes and tradition through innovation.

The new technologies, and, in particular, the 5G of which Matera is a testing centre, provide important support for the enhancement and protection of the landscapes of smaller centres such as La Martella. The 5G, the new standard for mobile communication, goes in the direction of increasing the speed of connection for users and improving the quality of service to ensure a faster and affordable connection for everyone. It is not only an upgrade of $4 \mathrm{G}$ but also a platform that enables innovative services ranging from Internet of things (Iot) to self-driving cars and ensures very high download and upload speed.

New technologies and GIS are configured as a real 'laboratory' where it is possible to experiment and develop new methodologies of interpretation and new strategies of intervention. These technologies could also be applied to land systems as the sum of various sub-systems such as, for example, agricultural, settlement, industrial, environmental and road systems.

In this historical moment that is characterised by globalisation and the progressive removal of the individual from his roots, new technologies allow to maintain a link with his/her own community also through the possibility of perceiving, seeing and listening, even remotely, to his/her own cultural landscape. A community, in fact, recognises itself within a landscape where technologies are connecting modes that give way to connect citizens in real time. They also enhance agricultural production through traceability systems and dis- 
tricts through the promotion and knowledge of these productions, because they are not only products but also a synthesis of culture, traditions, processes, raw materials and biodiversity, all autochthonous elements of a site. Therefore, they are part of an identity path that men managed to create by giving their contribution to enrichment without, however, generating actions that can alter identity profiles (D'Antonio et al. 2020b).

The village of La Martella is developing forms of sustainable agriculture based on the recovery of traditional agricultural forms linked to self-consumption, solidarity and sharing, which are related to urban food gardening in the form of community gardens. La Martella is an interesting case study to analyse the impact of landscape management systems through new technologies in the light of a recovery of traditional forms and identity of production dynamics. The 5G allows a farmer from La Martella, who is far from his field at another point on the planet, to check in real time the threshing that is taking place, and 5G also plays the function of maintaining and reconnecting at each point their sense of belonging to the community by sharing virtual platforms, knowledge and practices.

The possibility of historicising a large amount of geodata will allow various users to monitor all situations potentially at risk, for instance road trees, the state of urban water canals, the surveillance of historical heritage-cultural, and make predictions and strategic projects in the short and medium term. Matera, in recent years, has been at the forefront in various areas. In order to pursue the good path undertaken, it seems necessary to make the best use of the great opportunities resulting from 5G.

The Lucanian area is naturally suited to agriculture, an undisputed witness of southern agricultural civilisation. However, this sector currently faces great difficulties due to the lack of competitiveness vis-à-vis of large international companies. Among the main themes of the project, Matera5g is the one linked to smart agriculture, that is accurate agriculture based on satellite systems and 5G technologies. In terms of fruition of cultural and historical contents, virtual reality is useful to touch the rock churches of Matera whereas augmented reality permits to manage the maintenance of marine engines in Bari. These are the first applications of Bari-Matera 5G, an initiative promoted by the Ministry of Economic Development to test the fifth generation mobile network in the field. In addition, with 5G, the neighbourhood community now becomes a virtual community and the management of cultural heritage can take place through the network thanks to the use of applications that promote accessibility and sustainability. Besides 5G technology, Matera introduced a number of best practices in digital access to historical contents, including virtual museums, online search programmes and digital platforms. 


\section{Matera Città Narrata}

The project Matera Città Narrata (http://www.materacittanarrata.it/) commissioned by APT Basilicata to CNR ITABC followed an innovative approach in redeveloping and enhancing the cultural landscape of the area of Matera (archaeological, historical-artistic, naturalistic, anthropogenic) through digital communication systems, which not only concern sites of excellence but also widespread heritage. It is an integrated, multidisciplinary and multidimensional cultural project, a virtual heritage network that ideally connects content, places, times, authors, users, real world and virtual dimensions. It is a digital platform that can support users both in the planning phase of the visit experience in Matera, and while the visit is in progress, by allowing visitors to orient themselves and access cultural content in near monuments, sites and itineraries. The project has created multimedia formats of enhancement of intangible heritage, thus generating a dynamic and open system of management of cultural content.

The contents are divided into four macro-sections:

- sites: there are 31 sites of Matera identified by the project and described in detail with dedicated sheets and in-depth content;

- itineraries: there are 6 itineraries identified by the project. From Piazza Duomo to Piazza Vittorio Veneto through the Sasso Barisano, from Piazza Duomo to Piazza Vittorio Veneto through the Sasso Caveoso, from Piazza Vittorio Veneto to Piazza Duomo going up along the Civita, beyond the Gravina, an excursion to the Tramontano Castle and an excursion to the Casa di Ortega;

- time passing by: 3D reconstructions of Matera and the surrounding areas have been carried out in 8 chronological phases: Upper Pliocene, Neolithic Age, Classical Age, Byzantine-Norman Domination, Swabian Domination, Renaissance-Aragonese Period, late 19th century period and the present day;

- witnesses: 17 illustrious people and 26 citizens of Matera were involved to contribute to the project. Thanks to some short films, including visions, memories and artistic performances, 5 additional witnesses, who are children from Matera, have been involved in collaboration with local schools.

\section{Activities}

- Creation of a website (http://www.materacittanarrata.it/) including all the contents of the project in double version (to be accessible from any computer or smartphone).

- Creation of an iPad application (including all project contents) downloadable from the App Store in the Education section. 
- Creation of an Android applications (related to 4 routes) downloadable from the Play Store in the Travel/Education section.

- Integration of users' localisation via GPS.

- Creation of a playful application for children on iPhone and iPod touch called 'O Munacedd', downloadable from the App Store in the Education section. It integrates user localisation via GPS.

- Creation of a complete guide in MP3 and PDF formats.

- Provision of mobile services, namely IVR, MMS and SMS.

- Creation of a backbone Wi-Fi in the Sassi of Matera with free access.

\section{The Multimedia City Memory Archive}

The Multimedia City Memory Archive is a tool for dynamic and flexible research targeted at several levels to different users. This archive includes photographic materials, local public and private photo libraries, a collection of graphic materials in the stalls of ecclesiastical institutions and nineteenth-century and contemporary cadastral materials in the international competition on Sassi. Documentaries belonging to the Istituto Luce and the Triennale di Milano as well as a roundup of films shot in Matera from the 1950s to present day can also be found in the archive. They are rich witnesses of urban landscapes in different eras. The composition of a multimedia archive of historical, graphic, photographic, cinematographic and documentary sources concerning the maternal site plays a fundamental and preparatory role to any type of management approach. There is a single multimedia container with ancient, less ancient and recent flashbacks, of which some are remote in the consciousness of the Matera community. A real mnemoteca, an archive of memory, helps to reconstruct the collective memory of our territory through the collection, filing and digitisation of historical sources dispersed and scattered in private and public archives.

\section{The MUV (Virtual Museum of Collective Memory of Matera)}

The MUV ${ }^{2}$ is a non-profit cultural association created to collect and share photographs, audio and video stories on the history of the city of Matera. It is one of the first museums of online memory participated, according to the philosophy of web 2.0. It is possible to register and upload your photos with the intent of sharing and collective-

2 For further information see: https://www.materawelcome.it/en/luogo/muv-matera-museo-virtuale-della-memoria-collettiva-di-matera/. 
ly exchanging materials, since the historical memories of a territory belong to the community and represent its identity.

\section{The Cultural Project Casa Noha}

At a stone's throw from the Duomo, Casa Noha involves the visitor in an evocative multimedia journey to discover the city and its soul. The walls of the Noha house become a theatre where the story of Matera is narrated, from prehistory to present day. The filmed story The Invisible Stones is an immersive experience. An extraordinary journey through the history of Matera, this project by Giovanni Carrada offers visitors the first complete reconstruction of the history of the city. A fascinating narration enhanced by the careful work of a team of specialists who have faced the complexity of the land from different perspectives.

Leaving Casa Noha, the journey continues thanks to the app Matera Invisibile. Sulle tracce di una città straordinaria, edited by Antonio Nicoletti, which is an exceptional guide that leads the visitor step-by-step to discover the secrets of Matera through five of its constituent elements, namely water, stone, light, time and spirit. The app is free and is available for Androis and iOS.

\section{I-DEA (Archive of Archives and Collections)}

The Institute Demo-Ethno-Anthropological (I-DEA) is one of the key projects of Matera 2019. It is proposed as a prototype laboratory for a new idea of cultural institution in the twenty-first century. It intends to be a public institution aiming at researching and representing the rich anthropological and cultural history of the Basilicata region through exhibitions, performances, research programmes and an online digital platform. To draw inspiration, compare and share practices and knowledge useful to fine-tune the start and implementation of the project I-DEA, the Foundation Matera Basilicata 2019 and the Dicem, the Department of European Cultures and the Mediterranean of the University of Basilicata organised the international conference Food for Art - Archives as Driver for 2019 Creative Communities in Matera.

The I-DEA has two programmatic aspects: the establishment of a centralised archival database of all the pieces stored in each collection or archive member of the network and the creation of a new exhibition structure in the Sassi of Matera, made through the conversion and extension of existing spaces. The exhibitions will be composed of elements from the archives of the network. By going beyond the understanding of the museum as a static space for the preservation of 
cultural artefacts, the notion of the museum as a public platform for speech and interpretation will be introduced. Guest curators will be invited to propose their interpretations in the form of temporary exhibitions that explore the history, culture and anthropology of Matera, the Lucan territory and Southern Italy.

\section{Co-Working Culture Space: Innovative Spaces for Accessibility to Culture}

The project carried out by the Joven Volunteer Association, funded by the Ministry of Labour and Social Policies Law 266/91 Directive 2015, aims to activate physical and virtual spaces in which young people can express their creativity. This experience took place in multidisciplinary laboratories and relates to research and development of digital systems and applications for accessibility. It is also connected with the study and identification of specific support related to places, paths and exhibitions which benefit from 3D printing. This includes the identification paths to illustrate the artistic-cultural heritage of the city via virtual tours designed for specific needs.

Through the sharing of knowledge, you can then imagine solutions, study strategies and design services aimed at the accessibility of the cultural and artistic heritage of the city of Matera.

\section{Casa-Cava}

This is a real jewel set in the excavated complex of San Pietro Barisano currently used as a hall for concerts and cultural interventions for its acoustic and phonic peculiarities. It extends over $900 \mathrm{sqm}$ and is made of nine rooms with an auditorium of 140 seats, one exhibition gallery, training rooms and laboratories, exhibition rooms and three outdoor courts. Casa-Cava is a complex predominantly hypogeum which consists of an ancient well quarry of post-medieval origin rediscovered and restored by the Office Sassi of the Municipality of Matera.

\section{Aroundly. Discovering Together}

Through the app Aroundly, it would be possible to move from the Sassi to the Cathedral, by walking through the rock churches and natural areas to discover the hidden heart of an ancient civilisation in the caves. Aroundly, developed by Informatica Srl, is an application available for free on Play Store and App Store (http://sassi. aroundly.it) which can provide an original route that is able to intercept traits and preferences on the basis of the responses of the 
traveller. Aroundly offers three possible solutions: embarking on a new journey, participating in a live trip and discovering the city. In the first case, the application returns a personalised trip structured in tabs which is easy to consult and describes in detail the surrounding places and the route to get there. The application allows you to share the journey with new friends, giving your stay in the European Capital of Culture 2019 a new perspective.

\subsection{Sustainable Tourism}

The Sassi, the Murgia, the gravine and the rupestrian churches are rich in natural architectonic barriers. However, this rock world seems to be made specifically to be explored with all five senses. The scents of the Mediterranean maquis, the flavours of the Mediterranean cuisine, the limestone rock, the different levels of humidity perceivable in underground environments, the tools of the peasant civilisation in its most disparate forms, the silence that conveys the feeling of being suspended in time are the forms through which the City of Stones is revealed to its visitors, whether they are disabled or not, while common sense continues to recount it as the inaccessible place par excellence.

Sustainable and responsible tourism is, first of all, open to all, without any exclusion or discrimination. The main aspects of this 'intelligent' tourism cannot be separated from its capacity to be a supportive, welcoming and inclusive phenomenon. Provocation and challenge are a chance to taste, enjoy, travel, feel, listen to, see, touch, breathe, and ultimately to live a place which is morphologically, culturally and historically extraordinary, however uncomfortable it might seem for people with disabilities and specific needs as well. In the past, Matera was a human environment attentive to natural resources and rich in solidarity values of neighbourhood. The use of 5G applications and advanced connectivity services encourage the establishment of an ecosystem favourable to the development of the economic chain of culture and creativity and allow each man to know and live his past and history by intertwining them with multiple projects and opportunities. Future artistic blending between tradition and innovation based on sustainability and the enhancement of national culture should also be considered. Thanks to mobility services to manage visitors and touristy destinations, new areas and a more accessible cultural heritage will be available to foster smart and sustainable tourism.

5G applications, such as augmented reality or the support of digital platforms dedicated to services, allow people with disabilities and specific needs to live a place morphologically, culturally and historically extraordinary. It also permits visitors to approach new 
technologies and people who are distant, as well as to explore these extraordinary historical places, for example, thanks to multimedia travelling. Projects based on digital applications, like digital museums and identification and mapping of routes truly accessible to all, were carried out in Matera.

\section{Multimedia Museum}

Inaugurated in the rock church of San Pietro Barisano, in the homonymous tufa district, the Multimedia Museum offers a chance for disabled people, people with mobility difficulties, elderly and minors to visit the rock heritage of the Sassi districts and the murgic area in three dimensions and in six languages, including Italian Sign Language (LIS) and braille language.

This initiative, introduced by the members of the cooperative Beyond Art, is linked to the project Sassi and Senses: know Matera Beyond the Barriers. Thanks to technology, even tourists with motor disabilities can travel virtually across the environments of rock churches and appreciate the underground which is normally off-limits to them. Visitors in the multimedia museum can also touch the rock environments 'to scale' with their own hands the plastic models of some churches.

\section{Social Trekking}

The project, funded by the Basilicata Region and the EPOS Programme 2012 and approved by the Italian Blind Union and Ente Nazionale Sordi, was created by the cultural association Sassi e Murgia in collaboration with the environmental education centre Lega Navale Matera-Castellaneta. Three touristy itineraries for the blind and the deaf were created in Matera in the Sassi, in the Crypt of Original Sin and at the WWF Oasis of San Giuliano. Social trekking is a form of trekking truly accessible to everyone according to the limits and difficulties of each. The proposed itineraries aim to combine knowledge of local artistic and natural heritage with education to sustainable development and the correct use of water resources since the culture of attention to landscapes is both a common good and an economic, cultural, ecological, environmental and social resource.

These itineraries are designed specifically for the blind and adapted, with the help of interpreters of LIS (Italian Sign Language), to the needs of the deaf. There is sight support for those who cannot hear as well as touch and hearing for those who cannot see. In this way, the deaf can 'perceive' the world whereas the blind can 'observe' it. 


\section{Matera Mare. Accessible Destinations and Itineraries}

The project, coordinated by the Basilicata Region, involves private social associations rooted in the region, non-profit associations engaged in social integration of people in difficulty and the Italian Tourism Institute for All. Matera Mare is a specific initiative aimed at identifying, mapping and processing data in relation to the theme of accessibility in the Lucanian area.

The project consists of the following:

- a web platform, simple to use both to access and manage data and to input new information;

- paper-based travel tools, designed and composed to provide clear and readable information;

- a tale of experiences from individual points of view.

Information was collected and organised on Map 1.0. The work of mapping the itineraries is enriched by additional data and stories which are summarised in maps and divided by theme.

The routes are divided into three types:

- urban routes that do not have jumps in altitude and, by their nature, have elements that can be identified as facilitators for orientation;

- mixed pedestrian/vehicular routes that have jumps in altitude but can be solved with ramps or slides in a reversible and light perspective (e.g. paths with gradelle or 'climbs').

- extra-urban trekking or bike routes.

\section{'Tutti nei Sassi'}

This design idea is to lead visitors to the discovery of the richness and uniqueness of a land that has its pivotal centre in the stones and extends to the overlooking plateau murgico. The type of visitor to whom this project is aimed at is anyone who has an interest in embarking on an exciting journey to discover a World Heritage Site, based on his wishes, needs and limitations. The three elements mentioned above are the pillars on which the proposed routes and their services were built, following a long and in-depth study phase and field experiences.

Sustainable tourism is also connected to the preservation of landscape and typical production. In this process of enhancement and protection, technology plays a crucial role. Matera is also promoting food and wine for sustainable tourism through the reconstruction of the supply chain of bread and through the valorisation and promotion of the typical bread thanks to the association of bakers, the Associazione per la Valorizzazione del Pane di Matera. Blockchain in 5G technology, besides giving precise information on every phase of the supply chain of the product, also allows to bring that same prod- 
uct back to a landscape that refers to an emotional imagination and to the memory of the past for those who lived in that area throughout their life. It recalls one's own childhood, before globalisation, but also participates in the creation and reconnection of collective memory which reinforces the sense of belonging and well-being of the community. In order to enhance sustainable tourism, the local administration of Matera has recently signed the E-matera: Pact for Sustainable Tourism in order to celebrate a new season of development and collaboration in the tourism sector. The objectives of the E-matera programme are the promotion of a model of sustainable development and widespread and lasting well-being of the region.

Based on the synergy between local administration and associations, E-matera promotes the restructuring of local economies enhancing traditional activities and prioritising hospitality facilities that reflect the special character of the city. It also focuses on the minimisation of the environmental impact by strengthening local supply chains and promoting the use of local products and services by visitors.

\section{Conclusions}

The use of digital applications in addition to 5G technology, of which Matera is a place of experimentation, is enacting important cultural transformations. What the neighbourhood community represented in the past in Matera now becomes a virtual community where sharing of knowledge, practices, beliefs and values, including the access and management of cultural heritage, takes place through a network with applications that promote accessibility and sustainability. According to this historical-anthropological prediction, it can be assumed that technology, with its extreme pervasiveness, will favour an even greater accessibility of historical places, in harmony with the conservation of cultural heritage, and will also encourage the dissemination of cultural content in the future.

The city of Matera has always been a welcoming land. The sense of community, solidarity and sharing are its peculiar features of living 'in the neighbourhood', which represented the typical model of settlement within the Sassi of Matera. Topographically, its neighbourhood consisted of a set of dwellings, partly dug into the tufa rock and partly built. They became a well around a courtyard and expressed, in the most immediate form, the sense of belonging to a community.

The neighbourhood was perceived as an autonomous system, as these units were, in environmental spaces which formed the nodes of a continuous and changing network in relational dynamics. There was no lack of positive values of solidarity and mutuality arising from the need to help each other. Interpersonal relationships were the most 
important type of relationships; they came from clear signs of need for survival. Matera breathed her human dimension in the neighbourhood and life flowed in a humble but very dignified context. Today, the European Capital of Culture 2019, mindful of that respect based on mutual understanding between individuals, promotes intercultural dialogue starting from acceptance and sensitivity, through the multiplicity of application of digital technologies, both for its citizens, who can find a renewed sense of cohesion through co-working spaces for ideas and arts, and tourists, thanks to the wide choice of virtual museums and immersive experiences provided in the city that enhance accessibility and sustainability.

The City of Stones wants to be a place free from obstacles and open to the knowledge of the other to show that culture, in all its forms, is an inclusive value. In addition, thanks to the E-matera programme, the city of Sassi focuses on sustainable tourism through the promotion of all those activities that offer visitors and residents facilities and services that encourage active participation, promotion of the landscape as a whole, sustainable agri-food production and food tourism respecting and enhancing local cultural heritage. 


\section{Bibliography}

Augé, M. (2009). Non-Places. An Introduction to Supermodernity. London: Verso. Bilò, F.; Vadini E.; Limana F. (2016). Matera e Adriano Olivetti. Testimonianze su un'idea per il riscatto del Mezzogiorno. Ivrea: Edizioni di Comunità.

De Martino, E. (1959). Sud e magia. Milano: Feltrinelli.

D’Alessandro, L.; Collina, S.; Affinito, M. (2020). I beni culturali nell'era digitale: tra tradizione e innovazione. Soveria Mannelli: Rubbettino.

D’Antonio, P. et al. (2019). "New Digital Systems for the Management of Cultural Landscapes". Mrdenović, T. (ed.), Decoding Balkan: Architecture, Urbanism, Planning = Conference Proceedings (Belgrade, 14-16 November 2019). Belgrade: Print and Promo, 48-52.

D’Antonio, P. et al. (2020a). "Le nuove tecnologie per la salvaguardia e la valorizzazione dei paesaggi dei centri minori: il caso di studio di La Martella, Matera". Damiano S. (a cura di), II recupero dei centri storici minori = VII Convegno Diffuso Internazionale (San Venanzo, Terni, 17-21 settembre 2019). Modena: Palombi Editore, 60-3.

D’Antonio, P. et al. (2020b). "Impiego delle tecnologie satellitari e $5 \mathrm{G}$ nella conoscenza e gestione dei paesaggi culturali: il caso di studio di Matera, $\mathrm{Ca}-$ pitale della Cultura Europea 2019". AIPH (Associazione Italiana di Public History) (a cura di), InVito alla Storia. Terza conferenza nazionale dell'Associazione Italiana di Public History \#AIPH2019= Book of Abstracts (Santa Maria Capua Vetere, 24-28 giugno 2019). Capua: AIPH, Associazione Italiana di Public History, 106-7.

D’Antonio, P.; Romano, F.V. (2019). "I Sassi, storie di vicinato e tradizioni agricole nelle evoluzioni del paesaggio". Cirillo, V. (a cura di), Matera. Trasformazione urbana tra architettura e fotografia. Grottaminarda: Delta 3 Edizioni, 67-76.

ELC (European Landscape Convention) (2000). "Council of Europe, European Landscape Convention". European Treaty Series, no. 176, 20 October. https://rm.coe.int/1680080621.

Lai, F. (2000). Antropologia del paesaggio. Roma: Carocci.

Morton, H.V. (1969). A Traveller in Southern Italy. New York: Dodd, Mead \& Co.

Salvarani, R. (a cura di) (2013). Tecnologie digitali e catalogazione del patrimonio culturale. Metodologie, buone prassi e casi distudio per la valorizzazione del territorio. Milano: Vita e Pensiero.

Tentori, T. (1976). "Social Classes and Families in a Southern Italian Town: Matera”. Peristiany, J.G. (ed.), Mediterranean Family Structures. Cambridge: Cambridge University Press, 273-87.

UNESCO (United Nations Educational, Scientific and Cultural Organization) (2008). Operational Guidelines for the Implementation of the World Heritage Convention. Paris. https://whc.unesco.org/archive/opguide@8en.pdf. 



\title{
Knowledgescape
}

Insights on Public Humanities

edited by Eugenio Burgio, Franz Fischer, Marco Sartor

\section{Fascist Monumentality in Bolzano and Trieste: Can Public History Help to Deal with it?}

Iris Pupella-Noguès

Université Paris-Est, France; Università degli Studi di Trieste, Italia

\begin{abstract}
When the multicultural regions of Trieste and Bolzano became Italian, the liberal state followed by the Fascist regime imposed an 'italianisation' of the 'allogeni' and of the spaces using monumentality and architecture. After the Second World War, both regions proposed Public History projects to try to appease tensions embodied by remaining Fascist monuments. The paper, by presenting several multimedia public history projects and analysing the link between local powers, inhabitants and the role of historians in the memory-making processes, wants to ask how Public History can be useful in dealing with the remains of Fascist monuments.
\end{abstract}

Keywords Fascism. Architecture. Public history. De-fascistisation. Trieste. Bolzano.

Summary 1 Introduction. - 2 Comparing Trieste and Bolzano. - 2.1 'Italianising' the Minorities. - 2.2 'Italianising' Urban Spaces: Architecture and Monumentality. - 3 After the Second World War: Constructing the Heritage of Trieste and Bolzano Fascist Material Monumentality. - 3.1 Bolzano: The Struggle for the Autonomy and the Rights of the German Community. - 3.2 Trieste: The Struggle for Italianity. - 4 What Can Public History Do with Remains of Fascist Monumentality?. - 4.1 Public History in Italy. - 4.2 Following the Traces of Fascist Monumentality: Guided Tours. -4.3 Investing Monumentality: Museums in situ. -5 Conclusion. 


\section{Introduction}

Fascist Italy is the state that has the most politically invested architecture in Europe. It has been a part of the politic conduct by the regime, and it invests urban landscape with recognisable aesthetics. Architecture is an instrument of power from which the consensus of masses is reached and it participates to the totalitarisation process of society (Nicoloso 2008, 7). The "stone Fascism" is the most indelible imprint that Benito Mussolini left on Italian soil (Gentile 2007, 3) and in fact, from 1945 to today, the fascist period has cast a long, indeterminate, shadow over Italian culture and politics. Hannah Malone wrote that "Fascism is an absent presence in Italy, as its memory is alive, but distorted, fragmented and obscured" (Malone 2017, 445).

A monument is an artefact that radiates, causes reactions around it in the public space, it can dissolve in normalcy but also sometimes become, once again, a conflictual political object. If history has for several decades already focused on understanding the conditions in which this monumentality was conceived and implemented, it cannot fully solve the problem of the place of fascist monuments in nowadays public spaces. Public history, however, is interested in history made outside the university and is particularly attentive to the public uses of history. This paper aims to analyse how Public History was used in the cities of Trieste and Bolzano and how it can contribute to appease tensions linked to the presence of fascist monuments remains in the public space. This paper will first analyse how the fascist regime intervened - considering both political precise measures in the border context and architecture - in the cities of Trieste and Bolzano. Then will deal with the after Second World War context, how the cities constructed the heritage of fascist monumentality. Finally, it will present how Public History has been used in Trieste and Bolzano by analysing a series of Public History projects realised since the beginning of 2010s.

\section{Comparing Trieste and Bolzano}

\section{1 'Italianising' the Minorities}

The areas of Trieste and Bolzano had frequently been compared for the study of the First World War, as being the location of several battlefields. The exit process of the war means for the two cities to newly be a part of the Italian kingdom after the collapse of the multicultural Habsburg Empire. In Trieste's area, Italian communities were mostly in urban centres, whereas hinterlands of the region were mostly inhabited by Slovenes and Croats. Nevertheless, Trieste and Gorizia 
also included important Slovene communities, which made the cities strongly multicultural (Pupo 2011, 12). In Bolzano's area instead, the separation between the German and the Italian communities was clearly marked. Bolzano was, in a very important majority, inhabited by Germanophones (Di Michele 2004, 80). The Italian immigration really started during the fascist regime. Once Fascism came to power, it operated a violent denationalisation of the German and Slavic communities. In Bolzano, Fascism was an 'import phenomenon': the Bolzano March of October 2nd of 1922, which caused the removal of the city mayor Julius Perathoner, had been realised by Fascists coming from the Julian and Trentino areas. Trieste, instead, was the first Italian city to have an organised fascist squadrismo as early as 1920 (Vinci 2009, 84). In fact,

far from being a mere reaction, the Fascist squadrismo was a crystallisation of previous nationalistic radicalism in the new context of post-war (and post-imperial) crisis. (Bresciani 2017, 51)

The fascist regime very quickly introduced laws and reforms that particularly concerned the provinces of Bolzano and Trieste and that were part of the process of 'denationalisation' of the 'allogeneic' populations.

\section{2 'Italianizing' Urban Spaces: Architecture and Monumentality}

In the cities of Trieste and Bolzano, the fascist regime used architecture as a way to 'Italianise' urban public spaces. In Bolzano, Fascism planned an entirely new, 'Italian' quarter or even a new-town west of the river Talfer: with its broad streets and vast squares, it stands in clear contrast to the small and narrow spaces of the historic Tyrolean city centre. In Trieste, Fascism completely destroyed and restructured the old town, right behind the Piazza Unità, the main square of the city, creating several 'political' buildings such as the Casa del Fascio, which is right in front of the ancient Roman theatre excavated by the fascist regime in 1939.

The first buildings that were built demonstrate the interest of the fascist regime for the First World War. In Trieste the Lighthouse of Victory [fig. 1a], made by the triestine architect Arduino Berlam, was inaugurated in 1927, as well as the Monument to the fallen soldiers [fig. 1b] designed by the triestine sculptor Attilio Selva and the architect Enrico Del Debbio, from Tuscany, who designed the Foro Mussolini in Rome. The monument represents a dramatic war scene with five naked and muscular men. An inscription appears on the marble pedestal "Trieste | to the dead of the Liberation War | 1915-1918" which is linked to how the fascist regime in Trieste saw the First World War. The monument is placed on the San Giusto Hill which 
Iris Pupella-Noguès Fascist Monumentality in Bolzano and Trieste: Can Public History Help to Deal with it?
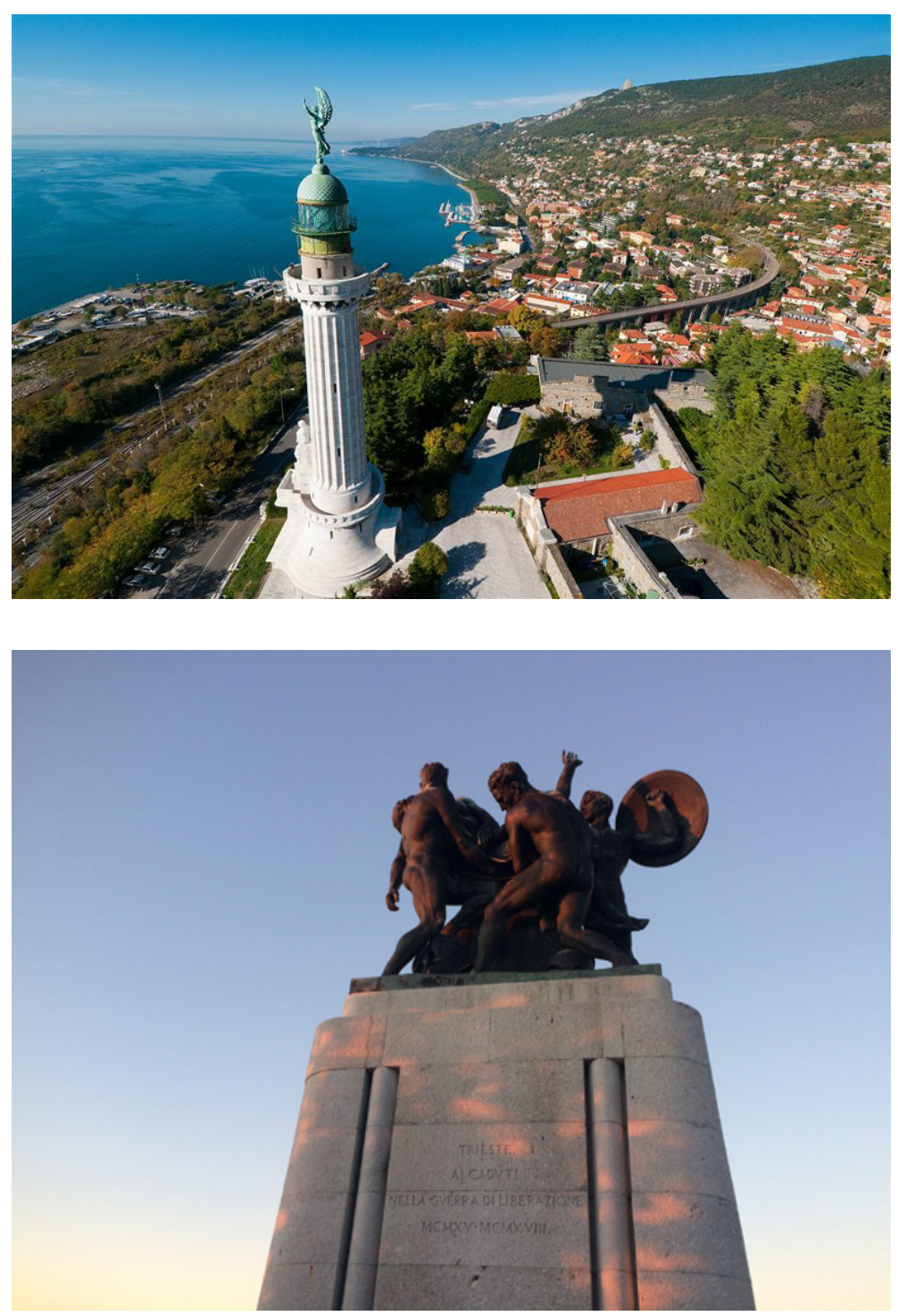

Figure 1a The Victory Lighthouse in Trieste, designed by Italian architect Arduino Berlam. Wikimedia Commons, CC BY-SA 4.0

Figure 1b The Monument to the fallen soldier in Trieste. The sculptural group was designed by Attilio Selva, the covering by Enrico Del Debbio. Photo by the Author 


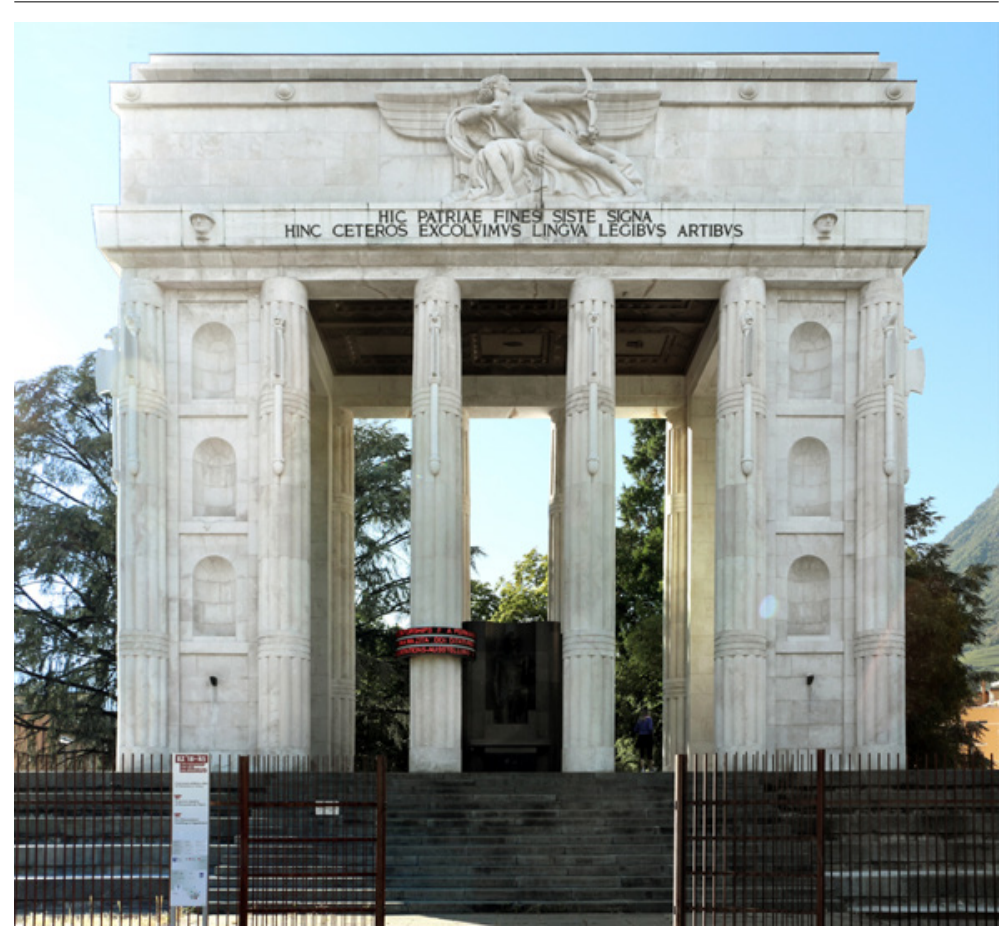

Figure 2 The Monument of the Victory in Bolzano, designed by architect Marcello Piacentini and built between 1926 and 1928. Wikimedia Commons, CC BY-SA 4.0

dominates the whole city, just in front of the San Giusto Cathedral. It was inaugurated in 1935 during a very important ceremony where the King Victor Emmanuel III was present to officially inaugurate the monument.

In Bolzano the Monument of the Victory [fig. 2] was designed by Marcello Piacentini, one of the most important architects of the regime, which underlines the importance that has been given to this first monument of the fascist regime ever erected in Bolzano. The monument represents an arch dedicated to the victory of Italy over the Empire during the First World War. Inside the monument are the busts of Cesare Battisti, Damiano Chiesa and Fabio Filzi, Italian patriots, considered as heroes by the fascist regime. On the top of the monument, the inscription "Here at the border of the fatherland set down the banner. | From this point we educated the others to language, law and culture", which directly aims the Germanophone community of Bolzano.

In both cities a Casa del Fascio (where are the local headquarters of the National Fascist Party) was built. The Casa del Fascio of Tri- 
este [fig. 3a] was made by triestine architects Raffaello Battigelli and Ferruccio Spangaro. The town development plan of 1934 required the new Casa del Fascio be placed in a symbolic spot: near the hill of San Giusto, in front of the rediscovered Roman Theatre. It was also the first and largest modern building to be built on land freed from the demolition of the old city, which included the old medieval part of the city but also the Jewish district (Sardei 2008, 217). The works started in 1937 and the Casa del Fascio was inaugurated in 1942. The Casa del Fascio of Bolzano (1939-42) [fig. 3b] was part of the vast project of the city transformation by Fascism (Di Michele 2020, 159). To embellish the façade, the local sculptor Hans Piffrader was asked to create a bas-relief. The work is composed by 57 panels (Strobl 2015) and tells the history of Fascism triumphs, from the end of the First World War and the upheavals of the so-called 'red biennium' to the birth of the fascist movement, the seizure of power, the conquest of the empire, the participation in the Spanish civil war up to the image of a peaceful, rich and prosperous Italy.

Amongst other fascists artefacts in the public space, there is a new railway station [fig. 4] in Bolzano built between 1926 and 1928, whose style reminds the Novecento Milanese (Bevilaqua 2003; Giuntini 2017). Interesting is its relationship with the landscape and, specifically, with the Rosengarten/Catinaccio, a characteristic range of mountains in the Dolomites. Both the northern bell tower and the central hall of the station frame the mountains and the height of the building and the connecting wings take into account the landscape in the background, according to a detail clearly intended by Ettore Tolomei (Tragbar, Kossel 2018, 195-6). In Trieste, the University [fig. 5] designed by Raffaello Fagnoni and Umberto Nordio is an important example of how Fascism wanted to impose 'italianity' in the city, in fact the University has been called "the most beautiful and most Italian monument of the whole new Trieste, the one of Mussolini". ${ }^{1}$ Benito Mussolini himself put the first stone of the future building during his visit to the city in September 1938. It is during this visit in Trieste that Mussolini announced the racial laws, underlining the importance of the city in the struggle for 'italianity' (De Sabbata 2008; Vinci 1997).

After the fall of Fascism in July 1943, from the 8th of September until the end of the war, both cities were occupied by the Third Reich.

1 “L'Università supererà tutti i monumenti e costituirà il più bello e il più italiano degli edifici della nuova Trieste, quella di Mussolini". Rivista Mensile della Città di Trieste, 6, 1938. Archivio Generale del Comune di Trieste. 
Iris Pupella-Noguès Fascist Monumentality in Bolzano and Trieste: Can Public History Help to Deal with it?
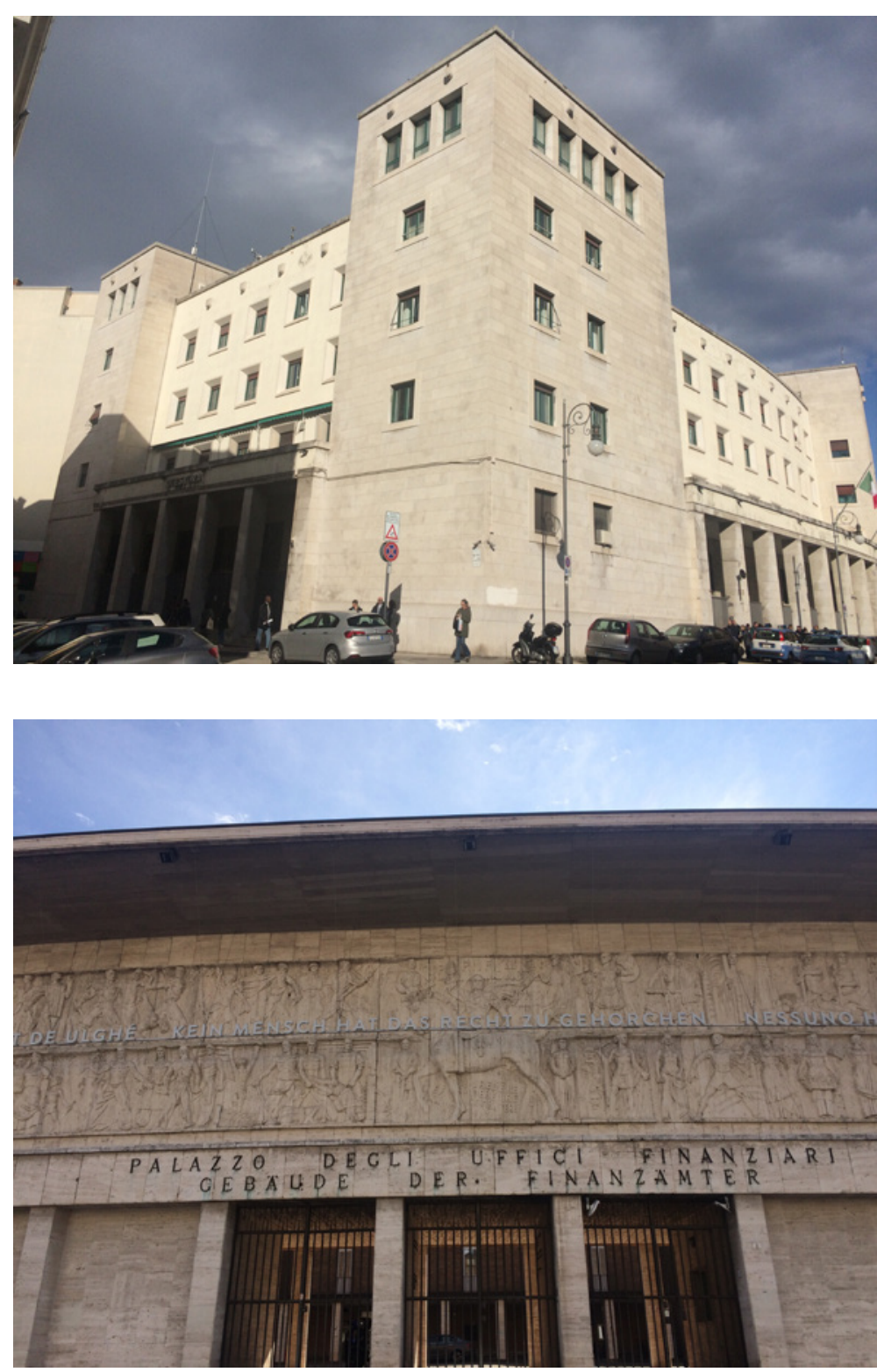

Figure 3a The ex-Casa del Fascio building in Trieste, now occupied by the police headquarters. Photo by the Autho

Figure 3b The ex-Casa del Fascio in Bolzano, now a financial office building. Photo by the Author 
Iris Pupella-Noguès

Fascist Monumentality in Bolzano and Trieste: Can Public History Help to Deal with it?
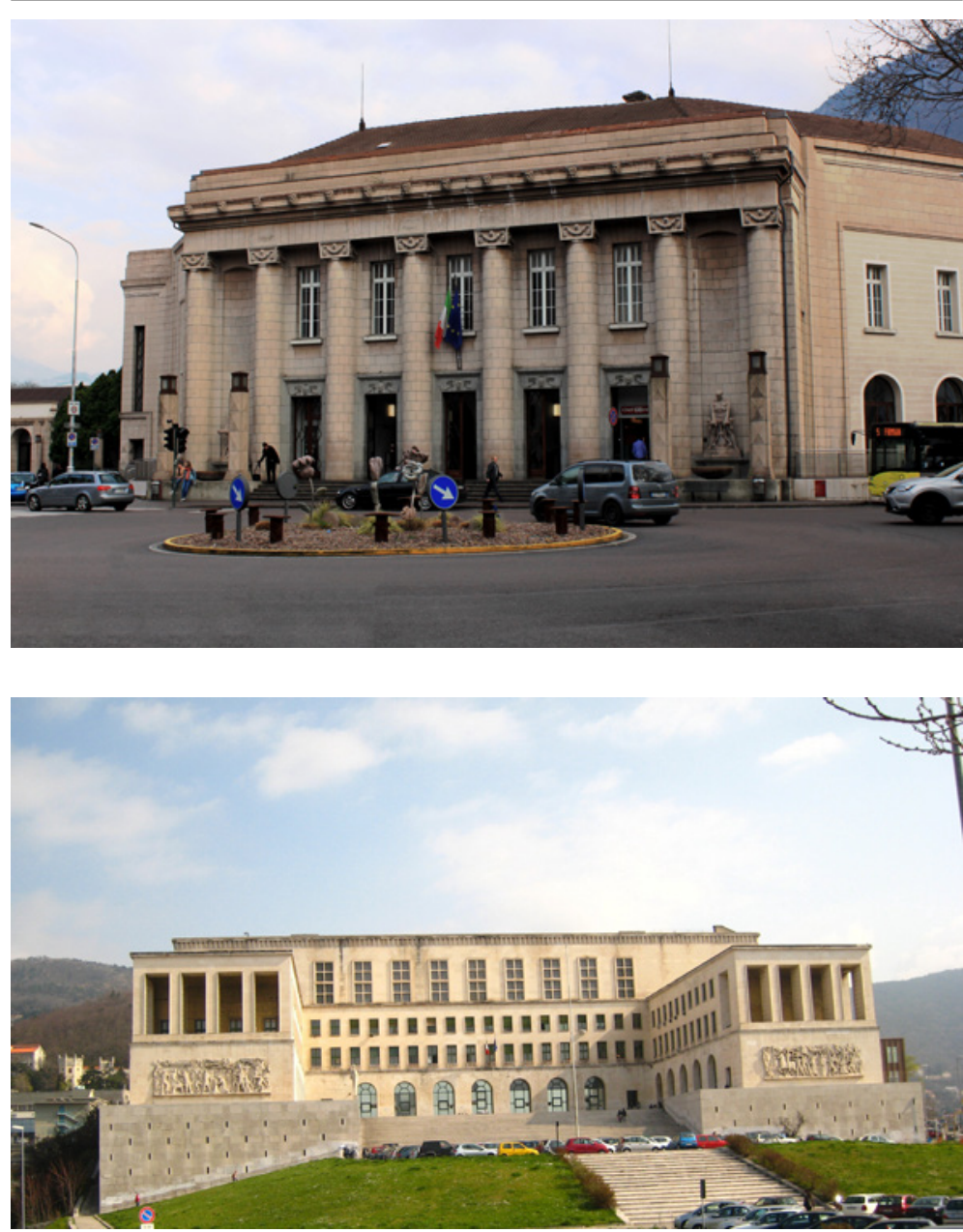

Figure 4 Bolzano railway station, built between 1926 and 1928. Wikimedia Commons, CC BY-SA 4.0

Figure 5 The headquarters of the University of Trieste, designed by Raffaello Fagnoni and Umberto Nordio. Wikimedia Commons, CC BY-SA 4.0 
Iris Pupella-Noguès

Fascist Monumentality in Bolzano and Trieste: Can Public History Help to Deal with it?

\section{After the Second World War: Constructing the Heritage of Trieste and Bolzano Fascist Material Monumentality}

\subsection{Bolzano: The Struggle for the Autonomy and the Rights of the German Community}

Bolzano starts its democratic process with the creation of the Südtiroler Volkspartei the 8th of May 1945, which have since the beginning the will to defend the rights of the Germanophone community after the violent 'denationalisation' operated during Fascism. The Südtiroler Volkspartei gives the push to a series of discussions for the autonomy of the province. On the 5th of September 1946, the GruberDe Gasperi (names of the foreign minister of Austria, Karl Gruber and the prime minister of Italy, Alcide De Gasperi) Agreement was signed. The Agreement granted the German-speaking population the right to autonomy and to preserve its cultural identity and customs. It also recognised German and Italian as official languages. Germanophones also granted the right to return to their original German family names. Nevertheless, the Agreement was not fully accepted by the German community, and the 1950s saw, for example, the creation of the South Tyrolean Liberation Committee (Befreiungsausschuss Südtirol, BAS), a secessionist and terrorist organisation which aimed to achieve the right for self-determination for South Tyrol and the related secession from Italy via bomb attacks.

Fascist monuments are quite at the centre of polemics and materialise the tension between the two communities. For example, the Monument of the Victory remained used by the Italian community to commemorate the First World War right after the end of the Second World War. But the German community quickly questioned the presence of the fascist monument. Two voices were then in opposition: the one that considered the monument untouchable because it commemorated the (Italian) victims of the First World War and the one that wanted its destruction. There have been numerous public demonstrations organised by political movements and associations where the Monument of the Victory was the heart of the contestations until the 1st of October 1978, when a bomb exploded near the monument, which caused serious damages and after which the monument was fenced and in fact made inaccessible.

\subsection{Trieste: The Struggle for Italianity}

Trieste, after being occupied by the Yugoslavian forces for 43 days, from the 9th of June 1945 belonged to the 'A Zone' managed by the 'Allied Military Government of Occupied Territories' and became the 
Free Territory of Trieste. During this period, Anglo-Americans reused some of the fascist buildings such as the ex-Casa del Fascio as headquarters. This situation was quite frequent, because there was no specific policy of 'de-fascistisation' to eliminate traces of the dictatorship from Italian cities (Arthurs 2015, 289; Carter, Martin 2017, 345 ) and because it fulfilled practical needs. Thus, major institutions continued to occupy buildings that were created under the regime, offering striking symbols of the 'continuity of the state' (Pavone 1995). Also, the TV or cinema news programmes created by Anglo-Americans often showed the city's most important monuments, including fascist monuments - such as the Monument of the fallen soldiers or the Lighthouse of Victory - but Fascism was never mentioned. In fact, in the Anglo-Americans' vision, those monuments were built to commemorate the First World War, so it was, in a certain way, more acceptable. As a consequence, the presence of fascist monuments remains was very rarely questioned.

In November 1953, violent manifestations and strikes started in Trieste against the authority of the Allied Military Government and in defence of Trieste's italianity. The manifestations pushed the Allied Military Government, Italy and Yugoslavia to engage on a new peace treaty: on the 5th of October 1954, after eight months of discussions, the Memorandum of Understanding of London was signed. The treaty granted, amongst other things, the return of Trieste to Italy. The Treaty of Osimo, signed on the 10th November 1975 by the Socialist Federal Republic of Yugoslavia and Italy, definitively set the borders between the two countries.

In this large context of struggle for the defence of italianity carried out by some members of the (majoritarian) Italian community, fascist monuments quite kept their original symbolic purposes as being marks, 'proofs' of the italianity of the city, and were rarely challenged.

The importance of the context in which the uses of monuments take place is clearly demonstrated by the examples of Bolzano and Trieste. The assimilation Fascism/identity lies at the heart of a differentiated reception of the regime's architecture. So far, we can say that in Bolzano fascist monuments were at the heart of sometimes violent manifestations mostly linked to the claim of Germanophone populations for autonomy, which necessarily pushed to reactions of local authorities. In Trieste instead, we can see that fascist monuments, assimilated with a challenged - but victorious - italianity, tend to very quickly melt in the urban landscape, and not being the heart of contestations between the different linguistic communities. These constructions of fascist monuments' heritage since the end of the Second World War clearly influenced the Public History projects proposed in the two cities. 


\section{$4 \quad$ What Can Public History Do with Remains of Fascist Monumentality?}

\subsection{Public History in Italy}

The Italian Republic's moral basis is the Resistance and anti-Fascism. However, beginning in the late 1960s, and with a subsequent acceleration (especially at the end of the Cold War, with the collapse of the Italian Communist Party and the fall of Italy's first republic), the 'anti-fascist' narrative was challenged by a wave of revisionist historiography, with its leading proponent Renzo de Felice, who questioned the totalitarian aspect of Mussolini's regime and emphasised consensus instead of coercion (Arthurs, Ebner, Ferris 2017, 3). The crisis of antiFascism facilitated the rise of Right-wing parties, such as Forza Italia and Lega Nord (Malone 2017, 447). Revisionism drew the myth of 'italiani brava gente' to present the regime as harmless (Corner 2005, 1779; Fogu 2006, 147) and contributed to relativise fascist crimes. Around the same time as the 'post-fascist' party Alleanza Nazionale entered Silvio Berlusconi's coalition government in 1994, the historical narrative was being distorted to restore Mussolini's reputation through books, films and TV programmes that presented a trivialised and nostalgic view of the fascist period (Bosworth, Dogliani 2001, 7; Foot 2009, 122).

The end of Berlusconi's government coincides with the arrival of Public History concept in Italy. The 37th issue of Memoria \& Ricerca journal, edited by Serge Noiret, entitled "Public History. Pratiche nazionali e identità globale", was published in 2011. In 2016, the Italian Association of Public History was officially created with support of the International Federation of Public History and the Giunta Centrale per gli Studi Storici. In 2017, during the 1st Congress of the Association in Ravenna, Serge Noiret was elected its president. The AIPH's manifesto declares that Public History is an asset because:

The growth of a full and conscious citizenship passes through a more widespread knowledge of the past that allows the overcoming of prejudices and fears that are multiplying in the contemporary world. The practices of public history offer opportunities and tools for the critical understanding of the historical contexts and processes in progress, helping to face their complexity and avoiding solutions dictated by rancour or alleged 'identity' contrasts. For all this, public history is a precious resource for social cohesion, fostering understanding and encounter between people of different origins, of different generations and with sometimes conflicting memories. ${ }^{2}$

2 Il Manifesto della Public History italiana, which can be downloaded from https:// aiph.hypotheses.org/3193. If not otherwise stated, all translations are by the Author. 


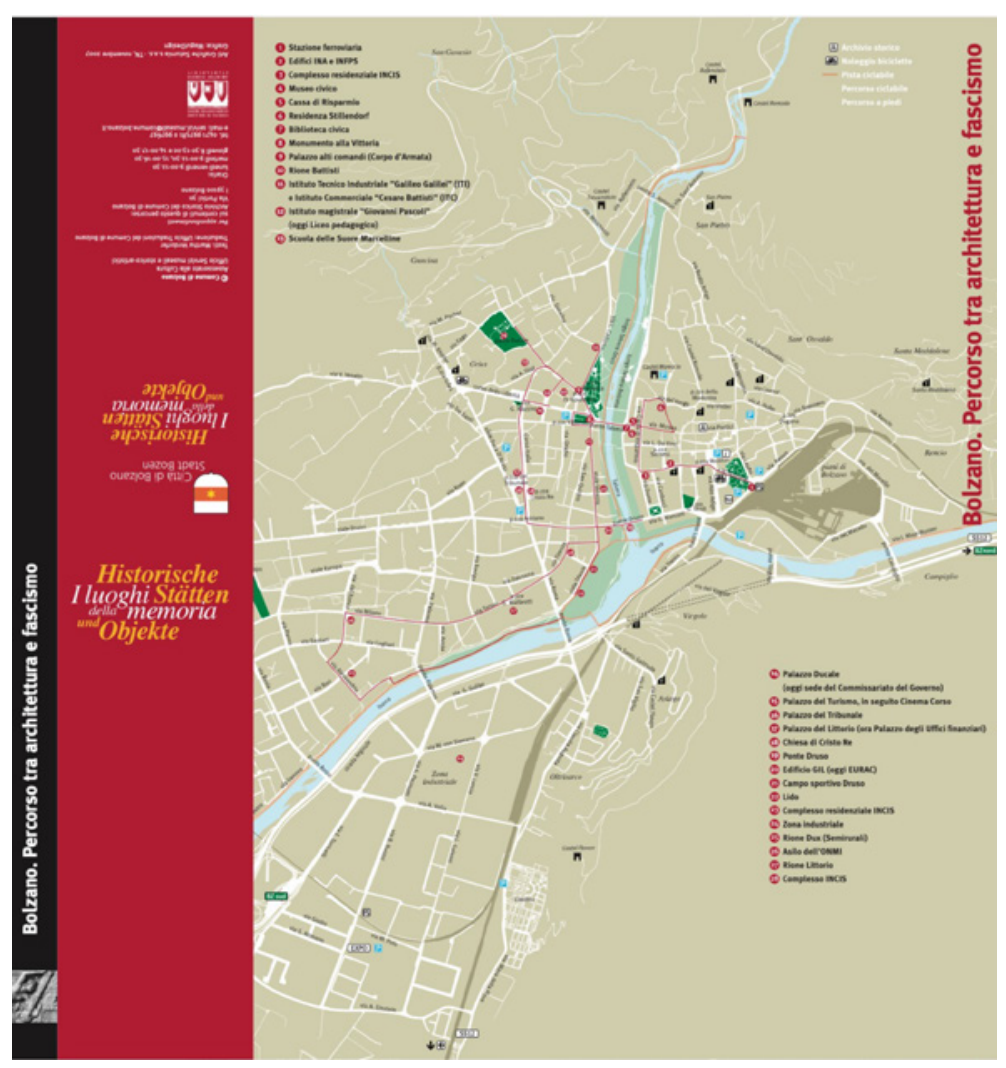

Figure 6 The brochure of the city of Bolzano, entitled Percorso tra architettura efascismo

Linking Public History with the "learning of citizenship", or the "overcoming of prejudices and fears" is particularly important when dealing with multicultural cities like Trieste and Bolzano, and that is really what Public History has to offer in those two contexts. In the following part, we are going to consider two kinds of Public History projects realised in Trieste and Bolzano: guided tours and museums.

\subsection{Following the Traces of Fascist Monumentality: Guided Tours}

From the ending of 2000's, both of the cities of Trieste and Bolzano proposed guided tours brochures to discover architecture and monuments from the fascist period. Bolzano's mayor was Luigi Spagnolli (from 2005 to 2015), elected with a coalition which brought togeth- 


\section{Itinerario dell'architettura razionalista}

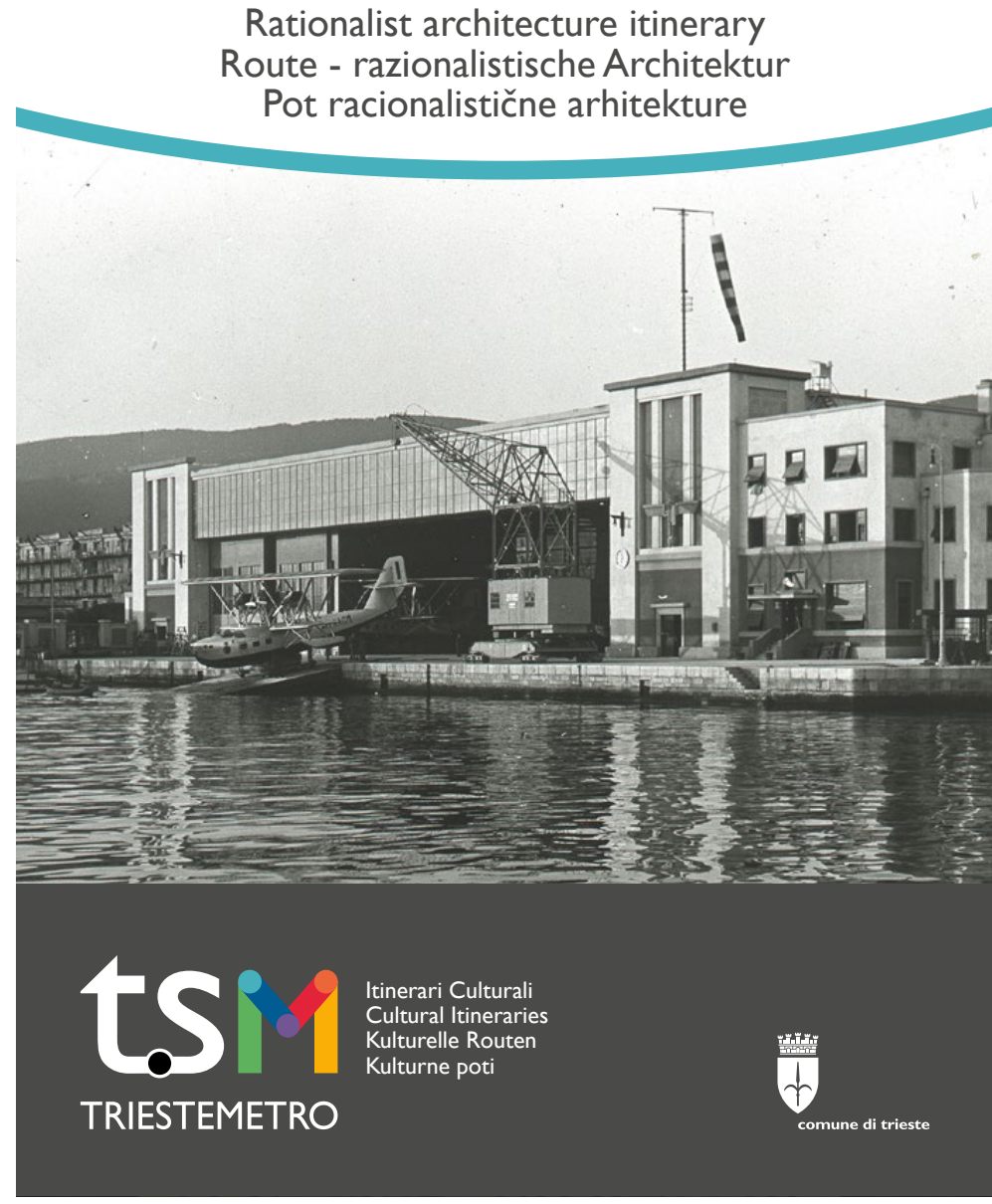

Figure 7 The 30-page brochure of the city of Trieste, entitled Itinerario nell'architettura razionalista

er Italian parties from the left and the centre (like the Democrazia e Libertà - La Margherita, or the Socialisti Democratici Italiani) but also the Südtiroler Volkspartei and the Ladins list. In Trieste, Roberto Dipiazza was the mayor (from 2001 to 2011) with a coalition which assembled a series of Italian centre, right and far-right parties like Unione del Centro, Forza Italia, Alleanza Nazionale and Lega Nord. 
The guided tours brochures are very different from one city to another especially in the vocabulary employed in titles and main texts which, in a certain way, concord with the political ideologies of the two municipalities. In Bolzano, the brochure (edited in 2007) is entitled "Percorso tra architettura e fascismo" (Tour between architecture and Fascism) [fig. 6], in Trieste, the brochure (also edited in 2007), is entitled "Itinerario dell'architettura razionalista" (Itinerary of rationalist architecture) [fig. 7], so from the outset we can see where the accent is put.

In Trieste, the brochure ${ }^{3}$ presents eleven monuments and buildings all erected from 1927 to 1942. In the whole brochure the word 'Fascism' is only mentioned three times: in the presentation of the itinerary ("The essentialised neoclassicism and the rationalist architecture of the fascist period in Trieste are of great interest"), in the description of Bagno Ausonia presented as "a very popular historic beach resort, in a vaguely fascist retro style" (we can underline the use of the word 'vaguely') and in the description of the University: "The construction of the university started in 1938. Designed by architects Raffaello Fagnoni and Umberto Nordio, it follows the fascist style of the 1920s with references to the classic period and italianity". The use of the word 'italianity' and also the mentioned reference to the classic period is interesting but not more explained in the description. In all others descriptions, the accent is put on architectural and artistic aspects, such as "[t]he building has a trapezoidal plan and has five floors. At the top, angular towers give an austere and institutional appearance to the white limestone building" for the description of the ex-Casa del Fascio, or, for the Lighthouse of Victory: "68 meters high, it rests on the bastion of the Austrian fortress Kressich (built in 1854). The lighthouse commemorates the fallen of the Great War with the statue of the Unknown Sailor by Giovanni Mayer, and the anchor of the destroyer Audace". There is no mention of the two lictor fasces present side by side of the Unknown sailor statue which have been removed in 1943, but whose marks we can still see today.

In Trieste, brochures are focused on the artistic aspect rather than the historical one, in Bolzano instead, the visitor can expect a tour dedicated to an architecture developed during the 20th century linked to a political regime: Fascism. The brochure presents 28 monuments and buildings all erected during the fascist period. Its aim is really to tell the history of the city during Fascism, using monuments, by assembling both historical and artistic descriptions such as the description of Druso Stadium: 
The sports stadium was inaugurated in 1931. The name is a reference to the Roman leader Drusus, who in $15 \mathrm{BC}$ conquered the area of Bolzano. It is one of many examples of fascist instrumentalisation of Roman history.

Or the ex-Casa del Fascio:

The building for the headquarters of the fascist party, the so-called 'Casa Littoria', was built between 1939 and 1942. The façade is slightly curved outwards, thus making it a pendant to the concave façade of the Palazzo del Tribunale in front of it. The building has a trapezoidal plan with an inner courtyard bordered on the sides by colonnades that hold the so-called arengario, the balcony from which the party officials held their meetings.

\subsection{Investing Monumentality: Museums in situ}

In Bolzano the monuments erected during the fascist regime crystallised the tensions between the Germanophone and the Italian community. Those remains of fascist monuments cause the organisation of numerous demonstrations in the public space and a multitude of debates. In the beginning of 2009, for example, some monuments of the fascist regime were in the centre of a polemic, where especially the Schützen, members of the association that wants to defend the cultures and traditions of Süd Tyrol, wanted the removal of the Monument to the Alpini. At that time, Luis Durnwalder, provincial governor, member of the Südtiroler Volkspartei, declared "[t]he bas-relief of the ex-Casa del Fascio and the Monument to the Alpini do not have any justifications anymore". ${ }^{4}$ Durnwalder suggested that the bas-relief would be put in a museum and also that the fascist monument to the Alpini could be replaced by a new monument that commemorate Alpini but erected inside of a military barracks (instead of in the public space). For Durnwalder, the Monument to the Victory must not be destroyed, but "placed in its historical context".

In the beginning of 2011, three historians, Andrea Di Michele, Hans Heiss and Hannes Obermair, launched a petition which wanted to solve the tensions provoked by fascist monuments. The petition underlined that the monuments must no longer be used either as "identity elements or as an opportunity to assert counter-identity", and invited to "finally historicise in a profound and effective way"

4 "Alto Adige: Durnwalder, spostare i monumenti di Mussolini e degli Alpini". ANSA, 10 febbraio 2009. 
the monuments. ${ }^{5}$ The petition disagrees on the idea of removing the monuments because it would create "new emotional waves, making it impossible to use them in an educational point of view and making a real take away". Following this petition, Bolzano's County and the City of Bolzano decided to gather a group of historians and archivists $^{6}$ from both of the language communities whose purpose was to create a permanent exhibition inside of the Monument alla Vittoria.

In 2014, the city of Bolzano officially opened the exhibition inside of the Monument alla Vittoria. The exhibition is in the undergrounds of the monument and uses different documents (from videos to posters in a modern scenography) to present the history of the construction and the life of the monument, adding reflections on how it has been perceived from the inhabitants or used by the different political regimes that succeeded until today, but also to tell and reflect on the history of Bolzano during Fascism and the nazi occupation. Outside the monument there is also an object, a LED light ring that circled one of the lictorian fasces, where the title of the exhibition is written. The aim is to notify any person that comes along the monument that there is something, that the monument has not been left as it is. The exhibition has been received in a very positive way from the inhabitants, and also from the Academy. It received a Special Commendation (the European Museum of the Year Award in 2016) that said the exhibition was the example of "what can be done with triumphalist architectural heritage that exists throughout the world", and "a highly courageous and professional initiative to promote humanism, tolerance and democracy" (Di Michele 2020, 164).

Regarding the bas-relief of the ex-Casa del Fascio, debates around its possible removal were contemporary to the creation of the Monument of the Victory exhibition. In 2011, after the petition of the historians, a call for ideas on how to make the bas-relief no longer directly visible was published. It is finally on November 5th, 2017 that was inaugurated the work proposed by Arnold Holzknecht and Michele Bernardi (local artists), who provided for the placement on the basrelief Hannah Arendt's phrase "No one has the right to obey", reproduced in the three languages of the province of Bolzano, German, Italian and Ladin.

In Trieste, some fascist monuments are generating several debates among historians, such as the Museum of Risorgimento which is in the Casa del Combattente near to the Oberdan sacrarium in the

5 The petition is available online: https://storiaeregione.eu/it/news-eventi/ leggi/risolviamo-insieme-il-problema-della-monumentalistica-fascista.

6 Andrea Di Michele (historian of contemporary history), Hannes Obermair (historian of medieval history), Christine Roilo (archivist), Ugo Soragni (architect), Silvia Spada (art historian). 
Oberdan square. The museum was opened in 1934 and its collection was added to the one present in the former (and smaller) museum of the Risorgimento in Trieste, opened in the early 1920s, and comprising a series of private archives and a few objects (Baioni 2006, 812 ). The new location of the museum in the city-centre and near the old cell where Guglielmo Oberdan was jailed gave a new impulse to the figure of Oberdan as a hero and martyr for Fascism. The museum presents the history of Risorgimento in Trieste - with a focus on the Irredentism aspect - and also the First World War with a series of objects, sculptures, paintings. All themes are presented following the fascist rhetoric: there is no mention of Slavic communities, or how violent and traumatic the First World War was for civilians; it presents instead a 'combative' spirit. Today, the museum is managed by the City Council and, from 2018, by the Lega Nazionale, an association created in Trieste in 1891, which defends the "italianity of Trieste". ${ }^{7}$ Almost nothing has changed since the opening and on the museum's website the word 'Fascism' is not mentioned once nor the period is explained. ${ }^{8}$ When I asked about this aspect to several persons in charge (from the City Council and the Lega Nazionale), they explained that the accent is put on artistic aspects: the building was designed by Umberto Nordio, a very important Triestine architect, and hosts Carlo Sbisà's works of art (which some of them have lictor's fasces, still today). Local historians disagree on what to do with this museum. Gaetano Dato, for example, underlined that it is a "fascist museum" but he thinks that it must be left as it is, because it allows to show how Fascism used to talk about the Risorgimento and the First World War (Dato 2012, 99-105). For others, it is impossible to leave it as it is and how the Risorgimento period and the First World War are represented (that is according to a fascist lense) must be explained to visitors.

In Trieste, there are two museums that have the credit to talk about the fascist and the nazi period in the city: the museum of the Risiera San Sabba and the museum of the Jewish community "Carlo e Vera Wagner".

The museum of the Risiera San Sabba is a museum created inside a 19th century factory which functioned during World War II as a nazi concentration camp for the detention and killing of political prisoners, and a transit camp for Jewish people, most of whom were then deported to Auschwitz. The camp also had cremation facilities, the only ones built inside a concentration camp in Italy, and were destroyed before it was liberated (Matta 2012; Fölkel 1979). In 1965, the Risiera San Sabba became a national monument and the muse-

8 https://www.museodelrisorgimentotrieste.it/. 
um was inaugurated in 1975. The whole in situ museum is a combination of exhibition spaces dedicated to the transmission and pedagogy and to the "historical" spaces of the Risiera such as prisoners' cells, which have been left intact. The exhibition spaces have been recently redesigned in a new scenography, using modern technologies adapted to museums, such as videos and sound systems.

The museum of the Jewish Community "Carlo e Vera Wagner" was opened in 1993, in a building where between the end of the eighteenth and the end of the nineteenth century there was an Israelite hospital which welcomed thousands of refugees fleeing first from tsarist antiSemitism then from Nazism. The Jewish Agency that assisted Jewish emigration to Israel was also located in the building (Wiesenfeld, Cusin, Haddad 1995). Between 2014 and 2015, the whole museum was refurbished. The museum tells the story of the Jewish community in Trieste since the Middle Ages until today, showing objects and documents of the Triestine Jewish community, and gives an important space to the fascist and nazi periods in the city and their consequences for the everyday life of the community.

\section{Conclusion}

Since 2015, monuments are investing major social debates. Movements for decolonising urban spaces, such as "Rhodes must fall" in South Africa, the Black Lives Matter movement, or the debate on the Mussolini's obelisk in Rome (Arthurs 2019) caused a renewed interest from the public at large (and not only historians) in questioning the influence of monuments in the public space in the whole occidental world. However, as Thomas Cauvin, professor of Public History in the University of Luxembourg and President of the International Federation of Public History, said to his students: "the first thing to do when dealing with problematic, sensitive monuments is to foster public discussion to see if the monument is unwanted and by whom, and in any case, removing the monument without discussion does not solve the problem".

In Bolzano, Public History projects have been initiated by the city, in collaboration with local historians, archivists, and inhabitants. The autonomous region and the city understood that those projects and, behind them, the work of explaining contemporary history were necessary to appease the tension between communities. However, it is clear that this has been made possible because the German community has a majority, so its revendications have a real echo for local authorities. In Trieste, fascist monuments have not been as questioned as in Bolzano. In fact, fascist monuments in Trieste quite melted in the urban landscape. But it does not erase the tensions and interrogations about the remains of fascist monuments in the public space. If Public History has been really used in Bolzano, it is not the case of 
Trieste, yet. But the creation of a Public History course held by professor Tullia Catalan in autumn 2020 at the University of Trieste, particularly focused on Public History in a border context and attended by students from all over Italy, will certainly have allowed new questions and new ideas on how to transmit the history of the fascist period in Trieste, through the presence of fascist monuments.

\section{Bibliography}

Arthurs, J. (2015). “'Voleva essere Cesare, morì Vespasiano': The Afterlives of Mussolini's Rome". Civiltà Romana. Rivista pluridisciplinare di studi su Roma antica e le sue interpretazioni, 1, 283-302.

Arthurs, J. (2019). "The Anatomy of Controversy, from Charlottesville to Rome". Modern Italy, 24(2), 123-38.

Arthurs, J.; Ebner, M.; Ferris, K. (2017). The Politics of Everyday Life in Fascist Italy: Outside the State?. London: Palgrave Macmillan.

Baioni, Massimo (2006). Risorgimento in camicia nera: studi istituzioni, musei nell'Italia fascista. Roma: Carocci.

Bevilaqua, F. (2003). "La stazione di Bolzano”. Cozzi, M.; Godoli, E.; Pettenella, P. (a cura di), Angiolo Mazzoni (1894-1979). Architetto Ingegnere del Ministero delle Comunicazioni. Milano: Skira, 145-53.

Bosworth, R.J.B.; Dogliani, P. (2001). Italian Fascism: History, Memory, Representation. New York: St. Martin's Press.

Bresciani, M. (2017). "The Post-Imperial Space of the Upper Adriatic and the Post-War Ascent of Fascism". Buchen, T.; Grelka, F. (Hrsgg), Akteure der Neuordnung. Ostmitteleuropa und das Erbe der Imperien (1917-1924). Frankfurt am Main: epubli, 47-63.

Carter, N.; Martin, S. (2017). "The Management and Memory of Fascist Monumental Art in Postwar and Contemporary Italy: The Case of Luigi Montanarini's Apotheosis of Fascism". Journal of Modern Italian Studies, 22(3), 338-64.

Corner, P. (2005). “La percezione del fascismo nell'Italia di oggi”. Giornale di Storia Contemporanea, 8(1), 176-83.

Dato, G. (2012). "Museo del Risorgimento e Sacrario Oberdan: rappresentazione storica e fonte per la storia dei musei”. Bolzon, I. (a cura di), I Centocinquant'anni dello Stato Unitario Italiano. Udine: RUE, 99-105.

De Sabbata, M. (2008). “Università”. Nicoloso, P.; Rovella, F. (a cura di), Trieste 1918-1954. Guida all'architettura. Trieste: MGS Press, 227-34.

Di Michele, A. (2004). "La fabbrica dell'identità. Il fascismo e gli italiani dell'Alto Adige tra uso pubblico della storia, memoria e autorappresentazione". Geschichte und Region/Storia e Regione, 13(2), 75-108.

Di Michele, A. (2020). "Storicizzare i monumenti fascisti. Il caso di Bolzano". Geschichte und Region/Storia e Regione, 29(2), 149-67.

Fogu, C. (2006). "Italiani brava gente: The Legacy of Fascist Historical Culture on Italian Politics of Memory”. Lebow, R.N.; Kansteiner, W.; Fogu, C. (eds), The Politics of Memory in Postwar Europe. Durham: Duke University Press, 147-76. Fölkel, F. (1979). La Risiera San Sabba. Milano: Mondadori.

Foot, J. (2009). Italy's Divided Memory. London: Palgrave Macmillan.

Gentile, E. (2007). Fascismo di pietra. Roma; Bari: Laterza. 
Iris Pupella-Noguès Fascist Monumentality in Bolzano and Trieste: Can Public History Help to Deal with it?

Giuntini, A. (2017). "Management e progetti nelle ferrovie italiane fra le due guerre". Cozzi, M.; Godoli, E.; Pettenella, P. (a cura di), Angiolo Mazzoni (18941979). Architetto Ingegnere del Ministero delle Comunicazioni. Milano: Skira, 99-121.

Malone, H. (2017). "Legacies of Fascism: Architecture, Heritage and Memory in Contemporary Italy", in "The Force of History: Modern Italian Historiography and the Legacy of Christopher Duggan", special issue, Modern Italy, 22, 445-70.

Matta, T. (2012). Il Lager di San Sabba. Dall'occupazione nazista al processo di Trieste. Trieste: Beit.

Nicoloso, P. (2008). Mussolini architetto. Propaganda e paesaggio urbano nell'ltalia fascista. Torino: Einaudi.

Pavone, C. (1995). Alle origini della Repubblica: scritti su fascismo, antifascismo e continuità dello Stato. Torino: Bollati Boringhieri.

Pupo, R. (2011). "Il fascismo di confine. Una chiave interpretativa per un approccio comparative". Geschichte und Region/Storia e Regione, 20(1), 11-19.

Sardei, I. (2008), "Casa del Fascio". Nicoloso, P.; Rovella, F. (a cura di), Trieste 1918-1954. Guida all'architettura. Trieste: MGS Press, 217-22.

Strobl, W. (2015). "Mussolini im Gewande Neros. Subversives und Zensur in der Kunst einer Grenzregion des faschistischen Italiens". Geschichte und Region/Storia e Regione, 24(2), 170-84.

Tragbar, K.; Kossel, E. (2018). “Conquest Through Architecture? Italy's Strategies of Appropriation in Alto Adige and the Trentino After 1920". Klabjan, B. (ed.), Borderlands of Memory. Adriatic and Central European Perspectives. Oxford: Peter Lang, 189-212.

Vinci, A.M. (1997). Storia dell'Università di Trieste: mito, progetti, realtà. Trieste: LINT. Quaderni del Dipartimento di Storia, Università di Trieste 4.

Vinci, A.M. (2009). "Il fascismo al confine orientale". Algostino A. (a cura di), Dall'Impero austro-ungarico alle foibe. Conflitti nell'area alto-adriatica. Torino: Bollati Boringhieri, 77-94.

Wiesenfeld, G.N.; Cusin, S.G.; Haddad, A. (1995). Il Museo della comunità ebraica di Trieste 'Carlo e Vera Wagner'. Trieste: Rotary Club. 


\title{
Knowledgescape
}

Insights on Public Humanities

edited by Eugenio Burgio, Franz Fischer, Marco Sartor

\section{Digital Engagement, Diversity and Access in Museum Education}

\author{
Carlo Corsato \\ The National Gallery, London \\ Kate Devine \\ The National Gallery, London
}

\begin{abstract}
In the wake of 2020's Coronavirus pandemic, museums and galleries across the world were forced to close and many of these institutions turned to programming activities online rather than onsite. This paper explores that move from the physical to the digital realm through two case studies within the Learning and National Programmes department at The National Gallery in London. It addresses the obstacles and benefits of online working with two very different audiences, young people in education and a community group of people living with mental health difficulties. The paper seeks to elaborate on the specific challenges of working with these audiences and contribute to the development of best practice in the field.
\end{abstract}

Keywords Museums. Digital. Learning. Communities. Young people. Entertainment. Public engagement. Diversity. Inclusion. Mental health. Wellbeing.

Summary 1 Introduction. - 2 The National Gallery and Digital Engagement in Early Lockdown: An Overview. - 3 Young Adults and Peer-Learning: 'A Night with Art History Link-Up'. - 4 Museum Education and Wellbeing: Portugal Print. - 5 Conclusion. 


\section{Introduction}

In 2020 galleries and museums across the globe faced a crisis. For many in Europe it was the biggest since the Second World War. From March 2020 to March 2021, because of the ongoing Coronavirus pandemic, institutions in the UK, large and small alike, had first to operate under restrictions and ultimately close their doors during three national lockdowns. The impact of restrictions on social mixing was unsurprisingly dramatic: during the last quarter of 2020 alone, government-supported museums and galleries saw an $89 \%$ decrease in visitor attendance. In the absence of traditional audience engagement, institutions were left to explore new ways of reaching their public online rather than onsite (cf. DCMS 2021). The National Gallery in London was no different.

The question of 'access' and how it relates to the arena of digital programming in museums can be very hard to tackle. Culture and heritage institutions are frequently concerned with attempts to engage with larger audiences and increase visitor numbers, but much of the focus in the past has been on stimulating them to come to us, to visit a physical site. While the pandemic has had a devastating effect on many people's lives, it has also highlighted how enriching digital, at-home engagement with these same institutions can be, and has helped us to reassess what it means to engage with cultural institutions, and to consider the many different forms that 'access' can take. No doubt we will see many new and enriching perspectives on this subject as a result of the 2020 pandemic. This paper aims to offer a contribution to that conversation, providing an insight into some of the best practices developed by the National Gallery's Learning and National Programmes Department (henceforth 'learning department'). In particular, we will explore two digital initiatives, elaborating the challenges and obstacles faced in the process of moving to an online format, and reflecting on both the positive and negative aspects of museum access in the virtual realm.

The programmes discussed in the present paper were very different in nature and scope.

The first engaged with young adults and sixth form students, with a majority from backgrounds that are currently underrepresented in the arts and heritage sectors. The second centred on therapeutic and creative community workshops for adults experiencing mental health difficulties. In order to facilitate activities and ensure positive outcomes, the department partnered with organisations that had a proven track-record of working with these specific audiences. Before we can fully appreciate the intricacies of these collaborations, and the actioning of strategies for digital engagement, we need to briefly discuss how they are situated within the Gallery's digital programming. 


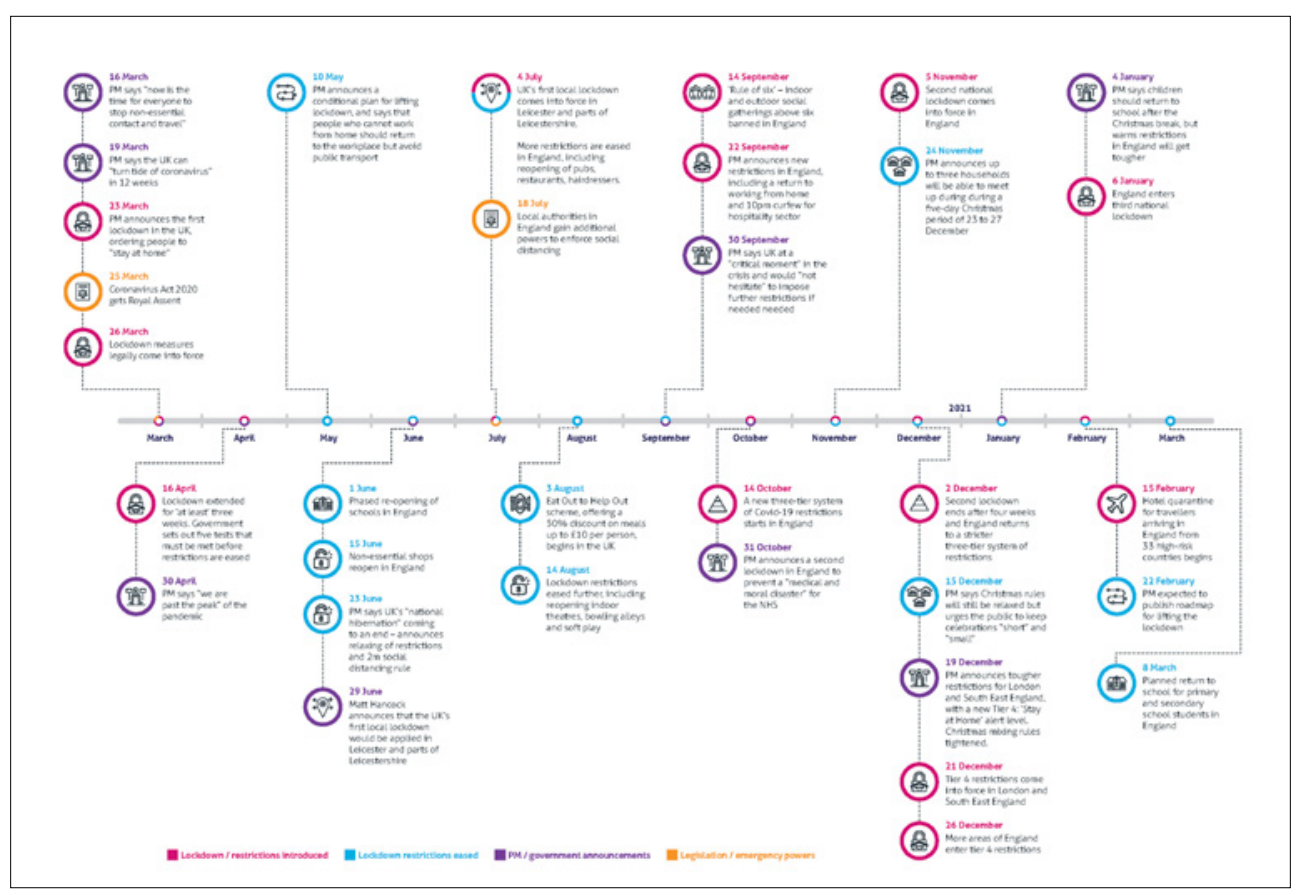

Figure 1 Timeline of UK Coronavirus lockdowns, March 2020 to March 2021 Institute for Government analysis, CC BY-NC 4.0 (https://www.instituteforgovernment.org.uk/ charts/uk-government-coronavirus-lockdowns)

\section{The National Gallery and Digital Engagement in Early Lockdown: An Overview}

In March 2020, the unprecedented impact of a global pandemic forced the Gallery to rapidly reconsider its relationship with its national/international audiences. A quick look at the timeline of UK Coronavirus lockdowns over the last year reveals how public health necessities forced an overall reconsideration of what constitutes museum access [fig. 1]. Social mixing, gathering in groups and using public transport were to be avoided, and school education was confined to home. Accordingly, visitor numbers decreased by $86.43 \%$ in October 2020, which was the best performing month of the year, with numbers dropping as much as $98 \%$ in November 2020 compared with 2019 figures (cf. DCMS 2021). How could the Gallery uphold its commitment to ensuring "the widest possible access to the national collection of paintings", the central tenet of its access policy? Reviews in 2010 did not include any reference to live-streamed learning, let 
alone digital engagement via video conferencing software platforms. ${ }^{1}$

Although nobody could anticipate that video conferencing and webinars would become a common practice for remote learning and cultural consumption, ${ }^{2}$ the Gallery could trust some very encouraging indicators related to the pre-existing digital offer. Visits to the Google virtual tour were up $642 \%$ compared with the period before the advice to 'stay at home', an increase of over $3,000 \%$ on the same period the year before. And visits to the virtual tour pages were up 506\% in April 2020 compared to the period before lockdown, an increase of $2,000 \%$ when compared to the same time the year before. The Gallery's social media channels experienced a similar uptick. From the 16th March, Twitter, Instagram, Facebook, and YouTube all experienced an increase in followers - particularly the YouTube channel which, it should be noted, contains the most in-depth content of all the Gallery's social media platforms. From March to October the Gallery produced 32 new films which have garnered 2.3 million views, averaging approximately 72,000 views per film with most people watching from start to finish. This in turn, generated 170,000 views of the website content, where people remained on average for 5-18 minutes on a single page (Shevlin, unpublished).

Unquestionably the appetite for online content was increased from the moment the doors were closed, however, the question for the learning team concerned how to best serve our very specific audiences in terms of learning and outreach programmes. Three factors, in particular, were crucial for the successful development of learning initiatives delivered through digital platforms.

1. A sizable in-house team of professionals with consolidated experience in museum education. This enabled the learning team to respond quickly to changing circumstances, develop new ideas, design original content, and collaborate in a way that would simply not have been possible if relying on educators and artists hired as independent contractors. The National Gallery is also fortunate in being a large enough team and indeed institution, which, exploring new ideas and piloting new models of working, carries only limited risk. We are able to weather a certain degree of failure, a fortunate position which is not always the case across cultural organisations at large. The 2017 Independent Review of Museums in England (The Mendoza Report) noted that "over the last 10 years, although nominally maintained, funding overall has re-

1 Cf. The National Gallery Access Policy, 2010: https://www.nationalgallery.org. uk/about-us/organisation/policies/access-policy.

2 Cf. Bakhshi, Humphries, Haq 2020, for a thorough analysis of how cultural consumption changed during lockdown. 
duced by $13 \%$ in real terms, with some museums seeing larger cuts". These considerable funding cuts led to a perception of museum learning as confined to the informal education of children and therefore, sadly, as a disposable asset (Mendoza 2017, esp. 55; Canadine 2018).

2. A commitment to engagement versus entertainment. The major benefit of online programming is the potential to reach vastly increased numbers of people. Undeniably, more entertainment-driven or lecture-based programmes at the Gallery have benefitted from increases in audience numbers of over $300 \%$. However, this expansion is only appropriate for a 'one size fits all' kind of event and it does not address issues relating to pedagogy, inclusion and wellbeing. While over 1,000 participants for educator-led lectures, or over 10,00040,000 views for entertaining and educational YouTube videos can certainly be considered a great achievement, ${ }^{3}$ when it comes to more individually enriching audience engagement and long-term learning, one-to-one support and group discussion bring about the best outcomes for the participants and thus necessitate smaller groups. Fortunately, the senior management of the learning department sees the value in both approaches and is willing to support small-group learning, where the measures of success are based on quality of experience, rather than numbers of participants. ${ }^{4}$ Connected to this approach, and reliant on the possibility for interaction and discussion, is the idea of building a sense of community through the department's programmes. Developing relationships and promoting wellbeing and togetherness through our programmes are aspirations that were severely impacted by the pandemic and the subsequent move to online provision (Soderstrom, Bjork 2015; Chen, Wu 2015; Brinkley-Etzkorn 2018). ${ }^{5}$

3. The use of modelling as an effective pedagogical strategy for museum education. As early as 1977, it was demonstrated that learning is exceedingly laborious, or even hazardous, if people have to rely solely on their own cognitive abilities (Bandura [1977] 2019). ${ }^{6}$ In fact, best practices in museum ed-

3 For instance, see the series A Curated Look and Decoding Symbols in Art on the Gallery's YouTube channel.

4 We are deeply grateful to Karen Eslea (Head of The Learning and National Programmes Department) for her support and insightful comments on the final draft of the present paper, and to Anne Fay (Public Programmes Manager) for her invaluable help.

5 Cf. also Liu, Elms 2019, with further bibliography.

6 Cf. Eggen, Kauchak 2001, with further bibliography. 
ucation reveal that processes of any kind need to be demonstrated, technical jargon has to be clarified with appropriate explanation, and new concepts and ideas require questioning from the learners. This type of audience-led approach encounters a plethora of obstacles in the online setting where audio delays, interruptions and switched-off cameras all present considerable barriers both to fluid conversation, and to creating a supportive space for discussion. The non-verbal cues, which may be obvious when educators and audience are sharing a space, are suddenly impossible to pick up on, and the mood and attitudes of participants are much harder to gauge. For this very reason, we introduced team-teaching as normal practice in the learning department's programming: this enabled the sharing of sophisticated contents and, at the same time, modelling of the learning process and prompting of the audience, eliciting their contribution throughout Q/A sessions (cf. RICHES Project 2016, with further bibliography).

Over the last year, these three factors proved to be essential for the production and delivery of digital learning activities on a weekly basis. The National Gallery's learning team was able to offer a regular schedule of highly customised, free-of-charge, online initiatives, and reconnect with a wide range of audiences that risked being completely alienated by the ongoing pandemic. Responses from teachers, parents, young adults, and the public, in general, were overwhelmingly positive regarding the quality of content, level of engagement, and accessibility. All of the factors mentioned above have a bearing of the two case studies that follow.

\section{Young Adults and Peer-Learning: 'A Night with Art History Link-Up'}

In November 2020, while a second lockdown was enforced in the UK, a live online workshop for forty-six form state-supported students was organised by the learning team in partnership with Art History Link-Up (henceforth AHLU). The educational charity was founded by Rose Aidin in 2016 to provide free A-Level Art History and Extended Project Qualifications for secondary-education students who do not have the opportunity to study this subject through their state schools. ${ }^{7}$ Fewer than 8 state-maintained schools in the UK currently offer Art History A-Level, while over 90 fee-paying schools do provide

7 In the UK except Scotland, A-levels are qualifications in specific subjects typically taken by school students aged 16-18. The equivalent in Scotland is the Higher. A-Lev- 
the course, contributing to perceptions that Art History is a subject which only the most privileged can connect with. This is a perception that has a real impact on the subjects people choose to study at university; in 2019 the number of students from state-maintained schools that applied to History of Art courses at Cambridge University was 35\% (UAS Cambridge 2020, esp. 16). ${ }^{8}$ The subject had the second lowest percentage of applicants from state schools across the arts, humanities and social sciences, second only to Classics. Numbers are moving in the right direction and yet still reflect a ratio of state-educated to privately-educated students that remains far from representative.

Based in London and running its courses on Saturdays at both the National Gallery and the Wallace Collection, AHLU has been particularly successful in attracting students from backgrounds that are significantly underrepresented in the creative and heritage sector. This charity may thus hold the potential not only to increase students academic achievements, but also to open up possible future career paths. Integrated into the formal A-level study, students have the opportunity to meet curators and other museum and arts industry professionals, giving them an academic qualification, and therefore a contribution to UCAS points, ${ }^{9}$ as well as an introduction to the industry and the jobs and roles available. Involvement with AHLU may constitute the only opportunity for many students to study art history, but it may also represent the only chance for young people, whatever their background, to get involved in the culture and heritage sector. Progress has begun to take place. A look at the most recent Arts Council's annual diversity survey reveals that the percentage of ' $\mathrm{BME}{ }^{\prime \prime 0}$ staff at Major Partner Museums (more than 2,000 institutions across the UK) was $5 \%$ in $2017-18$, which constitutes a $1 \%$ rise on the previous year. This compares to $12 \%$ at the arts council's other National Portfolio Organisations (about 663 institutions), and 16\% in the general population (cf. ACE 2019). Figures for museum attendance across

els are generally, though not always, necessary in order to progress on to university level education in the UK.

8 Partial data for Oxford University can be found in AASR Oxford 2020; remarkably, Art History is not listed among the subjects. Cf. also Perera 2019. It is worth noting that only $6.5 \%$ of the population attend fee-paying schools; those with a private education are disproportionately represented at the UK's most prestigious universities, with Oxford and Cambridge welcoming 31\% and 32\% respectively. Cf. Adams 2020 and Stoyanova, Hunter, Graham 2020. Data available on https://www. admissionreport.com/.

9 The UCAS (The Universities and Colleges Admissions Service) Tariff is used to allocate points to post-16 qualifications. Universities and colleges in the UK may use it when making offers to applicants.

10 BME stands for Black and Minority Ethnic background. It is often seen today as an outdated term but has been used in the ACE report and so is reproduced here in quotation marks. 
the sector reflect the same tendency. In 2018, $41 \%$ of all visitors were over the age of 55, while the proportion of young people (16-24) did not rise above $10 \%, 81 \%$ of which came from white backgrounds (cf. AA 2018). The National Gallery is striving to diversify its audiences and encourage young people of all backgrounds to feel that the arts and cultural sector is for them. The AHLU workshop was devised to respond to the urgency to give young people an opportunity to have their voices heard and their identities represented. ${ }^{11}$ In other words, the workshop wanted to be an event 'by', rather than 'for' the young people. This aspiration was then achieved with a three-way approach.

Firstly, the event was offered online, which overcame the most common economic barrier - access to public transport. ${ }^{12}$ Millennials and Generation $\mathrm{Z}$ are the most hyper locally-minded audiences, with $40 \%$ travelling less than 15 minutes to get to a museum (cf. AA 2018). The online format made it possible for $50 \%$ of participants to be based outside London and, therefore, able to access an art collection far from where they live. However, an online event posed a number of other challenges: how could watching screens offer the same hands-on experience of artworks that students would have during an in-person gallery visit? How could participants understand the display of the collection and the location of the rooms within the building, especially if they were not familiar with or had never visited the National Gallery?

To overcome these and many other issues, we had originally planned to live stream the event from the Gallery. With the support of two in-house audiovisual technicians, we wanted to offer an afterhours virtual tour, where participants could interact live and ask cameramen and presenters to stop in front of specific artworks. Unfortunately, the second national lockdown was enforced two days after we had made all the required arrangements and completed successful rehearsals. This option went straight onto the backburner and a new solution had to be found promptly, as the staff was soon to be no longer allowed onsite. We then undertook a carefully-planned photo shoot of over 300 pictures. A selection of this material was finally projected and commented on during the workshop to recreate the visitors' journey in the building and explain the organisation of the collections by artistic schools and historical periods. The ultimate purpose was not the artificial recreation of a real-life experience but

11 Carlo Corsato is most grateful to Margaux Portron (Young People's Programmer), responsible for the Young Producers Programme, for having supported the organisation of the AHLU workshop with passion and great generosity.

12 It should be noted that, while this event worked with young people who had access to digital devices and a reliable internet connection, this is not the case for all young people, many of whom have limited or no access to appropriate devices and internet connections 
rather the creation of an appetite for an in-person visit. The success of this strategy was confirmed by an evaluation survey conducted after the event: all participants confirmed their intention to visit, possibly with a friend or family member, as soon as travelling was safe.

Secondly, the content was developed and presented by two of the Gallery's 'Young Producers' (henceforth YPs). The Young Producers Programme was a long-running scheme within the learning department and involved young people (aged 16-25) for a full year, giving them the chance to organise public events and conduct public talks among a variety of other opportunities. Two talented YPs, 19 and 20 years old respectively, were equipped with project development skills and trained in public engagement by 3 professional educators under the supervision of the young people's programmer. ${ }^{13}$ Weekly meetings were organised and YPs could discuss the topics and themes they wanted to present; this resulted in a list of nine topics, exploring big concepts like tolerance, success, resilience, loneliness; these were linked to twelve paintings in the National Gallery collection, which included great masters, such as Botticelli, Michelangelo, Rembrandt, Bonheur, Manet and Van Gogh [fig. 2]. YPs were also coached through the scripting process and trained in presenting skills. In particular, speakers needed to consider that screen fatigue reduces audience attention and rapid back-and-forth conversations are badly affected by slow internet connections. Group and individual rehearsals were therefore organised and YPs acquired the confidence and skills to simultaneously present and interact with their online audience [fig. 3]. As a measure of success, the evaluation survey recognised that YPs were considered knowledgeable, passionate and engaging, with one respondent saying that "these speakers were spectacular, they kept my attention and I felt I learnt a lot" (Corsato, unpublished).

Finally, the event promoted peer-learning and direct engagement. Young people are more independent thinkers and want to learn, create and curate their learning experiences. They thrive on activities in which their peers model the learning process and explain how to take ownership of new ideas (cf. RCMG 2004). However, the workshop's digital format could potentially become a barrier: the participants had to keep cameras and microphones switched-off for safeguarding reasons and the YPs had no real sense of their audience. While on the one hand digital interaction can alleviate social pressures associated with being together and boost confidence in voicing opinions, on the other, not being able to share the same physical

13 The production and delivery of the workshop A Night with AHLU required two project managers (Educator Carlo Corsato, Young People's Programmer Margaux Portron), two facilitators (Young Producers Olvia Eccleston and Juriyah Juyel), three trainers (Educators Carlo Corsato, Kate Devine, Jenny Staff). 


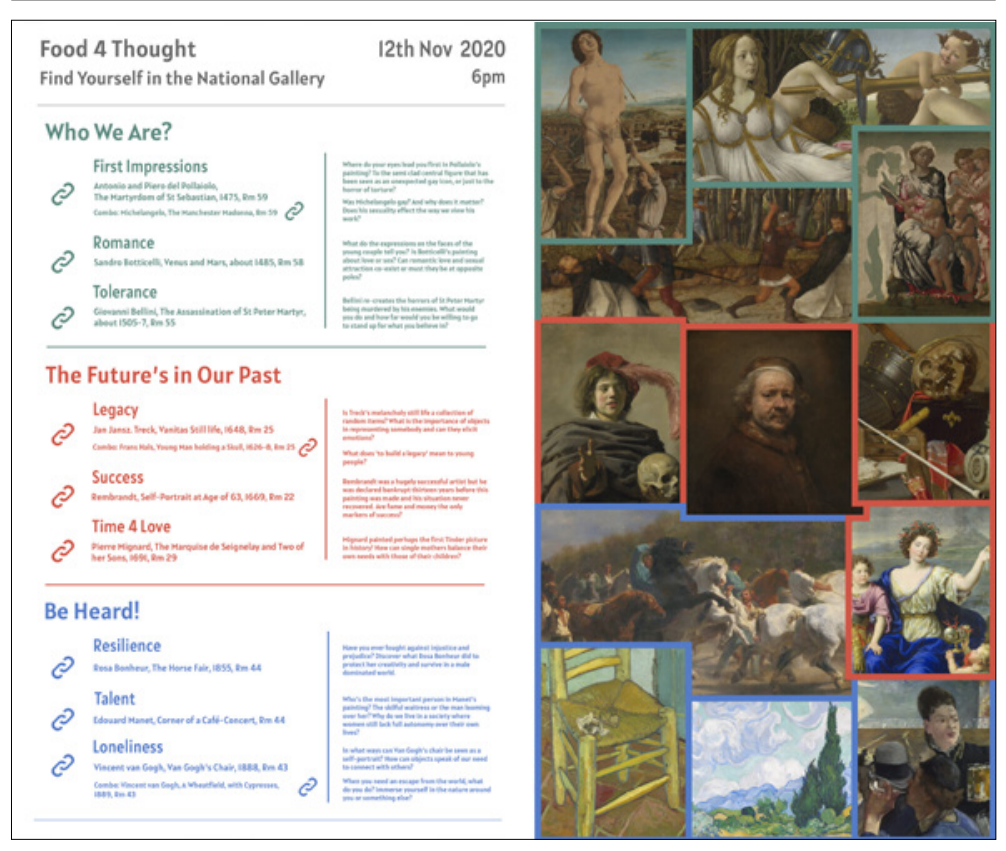

Figure 2 Handout for the online workshop A Night with Art History Link-Up (Graphic Design: Carlo Corsato). The National Gallery, London, CC BY-NC-ND 4.0

space may impact on the social aspects of the experience. We adapted to these challenges by adopting a twofold engagement strategy. First, high levels of interaction were enabled through interactive polling, in-meeting chat, and live Q/A available throughout the entire workshop. Secondly, to enable peer-learning and minimise adult intervention, young people's programmer and educators played only a supporting role; they monitored the video conferencing software platform and mirrored the audience in their questioning. The main purpose of this approach was to give full agency to young people by acting as a sounding board for their ideas, letting them take the lead and shape the content according to their interests. At the beginning of the workshop, the audience was given the power to vote for the themes and artists they wanted to explore. After a short briefing on how to use the digital platform, AHLU students could choose the workshop's content from an interactive poll that appeared on their screens. To facilitate an informed decision, they were provided with a digital handout in the form of a PDF menu, scripted by YPs in collaboration with educators [fig. 2].

The evaluation conducted after the event confirmed the success of this strategy. AHLU students described the National Gallery as 


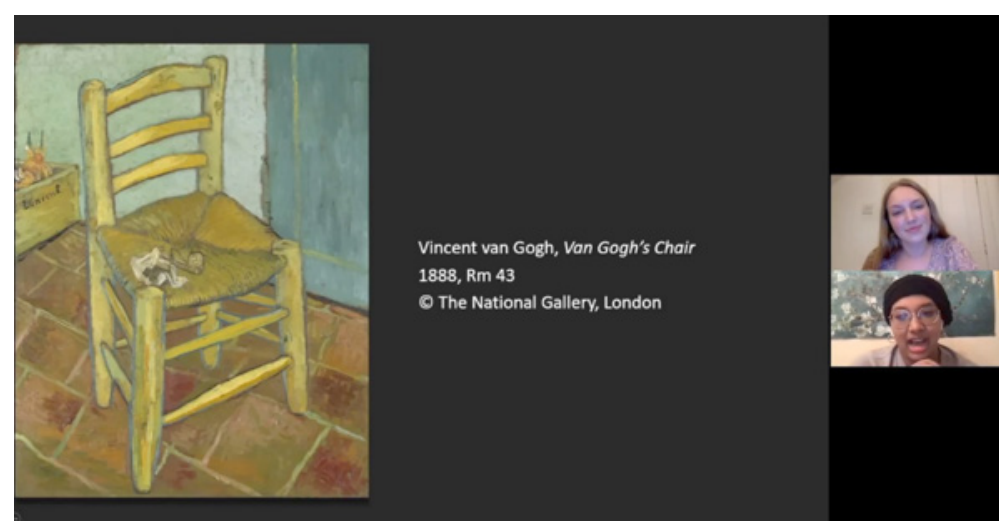

Figure 3 Olivia Eccleston (above) and Juriyah Juyel (below) presenting the online workshop A Night with Art History Link-Up. The National Gallery, London, CC BY-NC-ND 4.0

a "place where important questions can be asked and discussed" (Corsato, unpublished). It should be also noted that the vast majority of participants expressed an interest in attending, producing and delivering other events with the same format. This project certainly paved the way for a new approach that values young people as active protagonists of museum engagement, rather than as a passive audience to entertain.

\section{Museum Education and Wellbeing: Portugal Prints}

In February 2021 the Gallery's Communities and Access Programmer was contacted by the organisation Portugal Prints about the possibility of arranging a regular tour and practical workshop at the National Gallery for their service users. ${ }^{14}$ Portugal Prints is a London-based artists' community that offers creative programmes for people living with mental health difficulties. ${ }^{15}$ They are part of the mental health charity Mind in the boroughs of Brent, Wandsworth and Westminster, and open to referrals from people by a number of different routes. The charity has established a long-running and highly successful pro-

14 The Communities and Access Programmer was Anna Murray, and the Learning Assistant for the programme was Rachel McGiven.

15 Kate Devine wishes to thank the staff at Portugal Prints for their invaluable contribution to the success of the programme. In particular: Marta-Trias Gamito (Senior Creative Facilitator), Tatjana Damjanovic (Fundraiser and Creative Facilitator), Rebecca Jelly (Creative Facilitator), and Patrick Conlon (Manager). 
gramme of art workshops, gallery visits, and exhibitions, and fostered a wonderfully welcoming and supportive community of staff, volunteers, artist-participants, and partner organisations. At the time of writing, Portugal Prints supports a community of 35 artists from a range of interests, training and backgrounds, most of whom rely on state support. The community is approximately $60 \%$ male, $40 \%$ female, with $50 \%$ aged between 50 and 60 , statistics which reflect the makeup of the smaller group we worked with on this programme.

It was arranged that The National Gallery would host monthly visits from the Portugal Prints artists, a small group of around 12/15 participants supported by staff and volunteers from the charity. The sessions would comprise a short tour and discussion in the Gallery, followed by a practical art-making workshop in a dedicated workshop space. The importance of having the same National Gallery staff each month was paramount to maintain the sense of trust and community that the group had built together. ${ }^{16}$

The first session in the Gallery involved a visit to the temporary exhibition Young Bomberg Old Masters (Cork 2019), followed by a screen printing workshop. The feedback from the session was generally positive with particular emphasis put on the making activity, its physicality, and the fact that it was not something the group was able to do in their smaller studio space at the Portugal Prints site. In addition, the sense of collaboration was noted, the idea of working together, supporting each other and sharing. The educator had been able to chat to each of the artists individually, either casually during the session or when helping with the printing process, and by the end of the day felt that staff and artists had developed a warm rapport already.

Having said this, some difficulties were also brought to light. The overcrowded nature of the Gallery, which is a perennial problem, had triggered feelings of anxiety in some of the participants, and the physical effort of walking through the building and standing up for about 20 minutes in the exhibition space had been a struggle for a few people too. In practical terms, for some it had been hard to see the paintings properly among the crowds, and others who arrived later found it difficult to catch up with the group inside the large, sometimes confusing gallery space. While these were all difficulties that could have been, at least partially, alleviated with better planning and more staffing, the nature of the public gallery space is such that crowding and the discomfort and anxiety it can cause are some of the most difficult aspects to tackle for many of the groups we facilitate.

By June we were able to go back to the charity and offer them an online version of our initial arrangement and, by the end of the year, we

16 Sessions were developed and delivered by Educator Kate Devine with the support and advice of Learning Assistant Rachel McGiven. 
had been able to provide seven online sessions for the group, each one taking place on a virtual platform and each comprising an exploration of a particular theme and a short practical making workshop. Our approach had to be flexible and adaptable as we navigated different levels of lockdown. For several months all the participants attended from their respective homes but as restrictions were periodically eased the charity was able to open up its own studio to a limited number, meaning it was possible to arrange a blended teaching format, where some of the artists were together in a studio, with others tuning in from home. While numbers have been steady at these online workshops, we are still falling a few short of the number who attended our initial gallery sessions - the reasons for this may be various, but certainly an unfamiliarity and even distrust of video conferencing software has contributed.

Of course, a further hurdle has been our limited access to materials. When participants were able to come to our workshop at the Gallery, a whole host of materials was available and if any artists felt like doing something different to the planned activity, their needs could be accommodated; the sessions were, at least in part, led by them and their likes/dislikes. Moving online has meant planning simpler practical sessions with fewer materials to cope with the necessity of sending materials by post. Pared-down workshops have also been necessary to tackle the difficulty of modelling the activity online, but also that of supporting making and trouble-shooting along the way. The scope and complexity of the practical activities, therefore, diminished a little [fig. 4].

The relationship between the educator and the group has also changed somewhat. As previously stated, the role of an educator is as a facilitator, not a teacher or instructor in the traditional sense; where in the gallery space it was natural to initiate conversation and even debate around artworks, facilitating discussion online is a different and more stilted process, especially when participants are not yet used to the format. While some amount of back and forth is of course possible, anyone with experience of online teaching will understand the hesitant nature of such attempts, the inevitable extra time it takes and the fatigue that sets in. The effects on the sense of community are significant, with the role of workshop leader or teacher becoming more pronounced and less integrated.

One of the consequences of the digital platform is a reduction in one-to-one interaction, the difficulty of having a quiet word in the ear about something that you are struggling with, or do not understand. These casual interactions are extremely valuable when it comes to fostering trust and a sense of equality, and they are missed in the online setting. This said, the general mood and atmosphere in these online workshops has been a positive and convivial one [fig. 5].

While for many participants the move to online sessions may pale in comparison to being in the gallery in person, for others the anxiety 


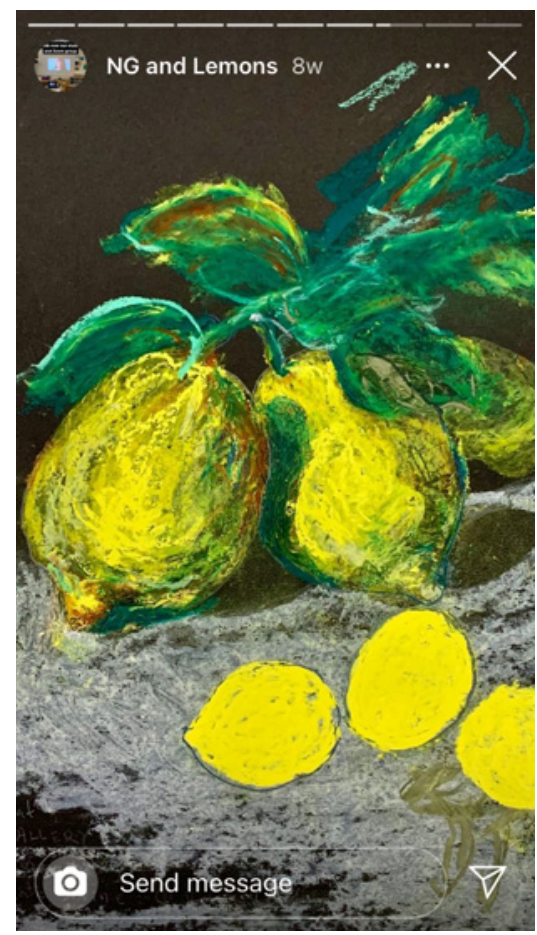

induced by busy rooms and new places was somewhat allayed by this digital format, in this sense it may be a more inclusive way of working.

Feedback from a survey conducted in January 2021 revealed that most participants would like to have the option to return to onsite programmes but they also valued having the option to work remotely too, preferring a blended format going forward wherein it would still be possible to attend from home or the Portugal Prints studio. The option of attending online also means that people can attend wherever they are in the country, or however they are feeling physically or mentally, the ability to drop out or take a quiet moment being so easy. So there are certainly pros and cons to this transition, but continuity of some kind of making sessions with us has certainly been appreciated and enjoyed. 


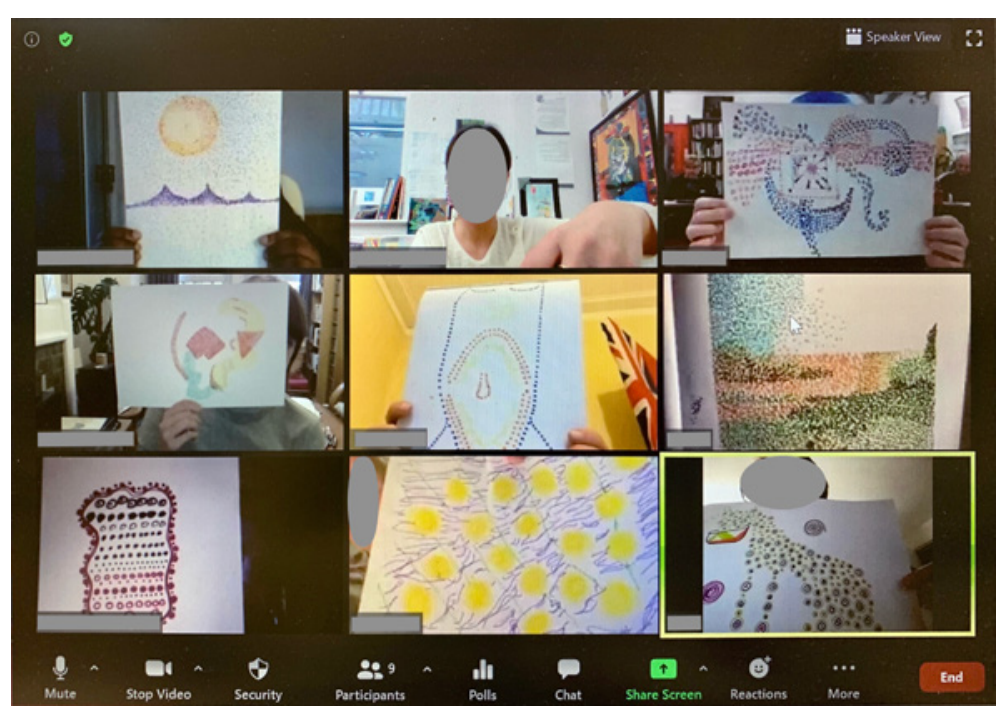

Figure 5 Live session with Portugal Prints. The National Gallery, London, CC BY-NC-ND 4.0

\section{Conclusion}

While moving to online learning formats has had its challenges and drawbacks, it has changed the way we think about museum access and engagement. As the world becomes more inclined to consume culture online, events like A Night with Art History Link Up prove not only to be a successful alternative to onsite programming, but an opportunity to share and learn new skills in working with online audiences and digital technology. For the artists at Portugal Prints, the ability to continue attending online workshops has not only provided some diversion in monotonous lockdown periods, but also enabled the gallery to maintain and grow our relationship with that community, and even to consider how a blended onsite/at home model might provide the best access to our collection and our workshops in future. 


\section{Bibliography}

AA (The Audience Agency) (2018). Museums Audience Report. What Audience Finder says about audiences for Museums. Official report (The Audience Agency), November. https://www.theaudienceagency.org/asset/1995.

AASR Oxford (2020). Annual Admissions Statistical Report. Official report (University of Oxford), May. https://www.ox.ac.uk/sites/files/oxford/Annual\%2๑Admissions\%20Statistical\%20Report\%20 2020.pdf.

ACE (Arts Council England) (2019). Equality, Diversity and the Creative Case. A Data Report, 2017-2018. Official report (Arts Council England), January. https://www.artscouncil.org.uk/publication/equality-diversity-and-creative-case-data-report-2017-2018.

Adams, R. (2020). "Record Numbers of State School Pupils Offered Oxford Places". The Guardian, 16 January. https://www.theguardian.com/education/2020/jan/16/record-numbers-of-state-school-pupilsgiven-oxford-places.

Bandura, A. [1977] (2019). Social Learning Theory. Englewood Cliffs (NJ): Prentice-Hall. Reprinted in Falk, R.; Kim, S. (eds). The War System. An Interdisciplinary Approach. New York: Routledge, 141-56.

Bakhshi, H.; Humphries, D.; Haq, S. (2020). Digital Culture - Consumer Tracking Study. Thematic report (Creative Industries Policy and Evidence Centre led by Nesta), June. https://www.pec.ac.uk/policy-briefings/understanding-how-our-habits-of-cultural-consumption-changedduring-lockdown-newest-survey-data.

Brinkley-Etzkorn, K.E. (2018). "Learning to Teach Online: Measuring the Influence of Faculty Development Training on Teaching Effectiveness Through a TPACK lens". The Internet and Higher Education, 38(1), 28-35. https:// doi.org/10.1016/j.iheduc.2018.04.004.

Canadine C. (2018). Why Collect? A Report on Museum Collecting Today. S.I.: Art Fund. https://www.artfund.org/assets/downloads/why-collect-report.pdf.

Chen, C-M.; Wu, C-H. (2015). "Effects of Different Video Lecture Types on Sustained Attention, Emotion, Cognitive Load, and Learning Performance". Computers \& Education, 80, 108-21. https://doi.org/10.1016/j.compedu.2014.08.015.

Cork, R. (2019). Young Bomberg Old Masters = Exhibition Catalogue (London, The National Gallery, 27 November 2019-1 March 2020). London: Yale University Press.

Corsato, C. (unpublished). Feedback - A Night with AHLU at the NG. Internal event evaluation (The Learning and National Programmes Department, The National Gallery), November 2020.

DCMS (Department for Digital, Culture, Media and Sport) (2021). Statistical Data Set. Museum and Galleries Visitor Figures - October to December 2020. Official report (Department for Digital, Culture, Media and Sport), updated 25 February. https://www.gov.uk/government/statistical-datasets/museums-and-galleries-monthly-visits\#history.

Eggen P.D.; Kauchak, D.P. (2001). Educational Psychology: Classroom Connections. 5th ed. New York: Macmillan. 
Liu, C.; Elms, P. (2019). “Animating Student Engagement: The Impact of Cartoon Instructional Videos on Learning Experience". Research in Learning Technology, 27. https://doi.org/10.25304/rlt.v27.2124.

Mendoza, N. (2017). The Mendoza Review: An Independent Review of Museums in England. Official report (Department for Digital, Culture, Media \& Sport), November. https://www.gov.uk/government/publications/themendoza-review-an-independent-review-of-museums-in-england.

Perera, D. (2019). "Redressing the Balance: Expanding Access in Private-School Dominated Courses". Varsity, 15 November. https://www.varsity. co.uk/news/18274.

RCMG (Research Centre for Museums and Galleries) (2004). Inspiration, Identity, Learning: The Value of Museums. The Evaluation of the Impact of DCMS/ DfES Strategic Commissioning 2003-2004: National/Regional Museum Education Partnership. Contributions by E. Hooper Greenhill, J. Dodd, M. Philips, C. Jones, J. Woodward, H. O'Riain. Official report (Research Centre for Museums and Galleries, Department of Museum Studies, Leicester University), June. https://le.ac.uk/rcmg/research-archive/inspiration-identity-learning-1.

RICHES Project (2016). Riches Think Paper 96. Museum Education with Digital Technologies: Participation and Lifelong Learning. Official report (RICHES Think Paper Collection, RICHES), April. https://resources.richesproject.eu/riches-think-paper-@6-museum-education-withdigital-technologies-participation-and-lifelong-learning/.

Shevlin, J. (unpublished). Lockdown Content Review. Internal report (The Digital Services Department, The National Gallery), November 2020.

Soderman, N.C.; Bjork, R.A. (2015). "Learning Versus Performance: An Integrative Review". Perspectives on Psychological Science, 10, 176-99.

Stoyanova, D.; Hunter, W.; Graham, C. (2020). "Five Years of University Admissions Statistics Reveals the Disadvantages Faced by State-educated Students". Varsity, 12 September. https://www.varsity.co.uk/ news/19783.

UAS Cambridge (2020). Undergraduate Admissions Statistics - 2019 cycle. Official report (University of Cambridge), June. https://www. undergraduate.study.cam.ac.uk/apply/statistics. 



\title{
Knowledgescape
}

Insights on Public Humanities

edited by Eugenio Burgio, Franz Fischer, Marco Sartor

\section{Una piccola provocazione. La pandemia e i modelli della Nouvelle Muséologie}

Antonietta Biondi

Sapienza Università di Roma, Italia

\begin{abstract}
The Coronavirus pandemic has also affected museum organisations and has inevitably brought back some of the strategies proposed by the museography of the 1970s. Methods of access, the ethical value of the museum and its social role involving local communities, have been key issues in the theoretical reflections known as Nouvelle Muséologie. The paper aims at presenting and discussing a number of case studies enhancing storytelling and the role of social media in public engagement during COVID-19 emergency in national and local museums in Canada and Italy.
\end{abstract}

Keywords Museology. Museum. Digital. Public. Collections. Pandemic crisis.

Sommario 1 Premessa. - 2 I musei sono fatti per il pubblico: l'attenzione del museo nei confronti dei visitatori. - 3 La Nouvelle Muséologie. - 4 Le questioni che il museo deve affrontare oggi. - 5 Senza limiti di tempo e di spazio il museo digitale è un luogo accogliente. - 6 Le nuove motivazioni della visita. - 7 II ruolo sociale di cui i musei si sono riappropriati. - 8 Raccogliere per ricordare. 


\section{Premessa}

Ho iniziato a scrivere questo contributo nel marzo del 2020, durante il tempo drammaticamente unico della prima ondata dell'emergenza sanitaria del Coronavirus. Oggi l'argomento è quasi inflazionato ma ritengo che possa essere comunque l'occasione per ragionare sulla fatale attualità di alcune delle strategie suggerite dalla museografia negli anni Settanta, quando, rispondendo alla crisi identitaria che si era abbattuta sui musei tradizionali, si proposero interventi metodologici, artistici e di riflessione politica che condussero a una nuova immagine del museo.

La situazione assolutamente unica prodotta dal lockdown ha come azzerato alcuni aspetti dell'attività museale del nuovo Millennio e presentato soluzioni sulla partecipazione del pubblico, sul valore etico e sul ruolo sociale di riferimento all'interno delle comunità locali che, negli anni Settanta dello scorso secolo, erano alla base della Nouvelle Muséologie. ${ }^{1}$ Lo sforzo fatto nel lungo periodo di crisi per mantenere attive e presenti delle istituzioni che non hanno senso in mancanza di visitatori ha reso merito a molte delle modalità operative che la Nouvelle Muséologie aveva teorizzato in anni già molto lontani. Non è mia intenzione ricostruire la storia di una parte importante della museologia ma, partendo da quella che chiamo una piccola provocazione, raccontare le attività realizzate da alcuni musei per tornare ad avere una dimensione sociale partecipata e un livello di inclusione particolarmente elevato.

Con la chiusura dovuta alla pandemia il museo ha mostrato, soprattutto nella sua dimensione digitale, un atteggiamento accogliente di avvicinamento all'utenza, allontanandosi dal carattere unidirezionale che spesso si rintraccia nella comunicazione e nella didattica. Ciò lo ha trasformato in uno spazio di libertà in cui il vissuto raccontato dai visitatori è divenuto un valore. Già da diversi anni la vera rivoluzione mostrata sul web, come ricorda Elena Bonacini (2012, 116), sta proprio nel nuovo ruolo dell'utente, che ha acquisito maggiore consapevolezza, competenza tecnica e capacità d'interazione con le piattaforme digitali.

L'articolo esamina alcuni assunti teorici - sui quali esiste un'ampia e diversificata bibliografia - che meglio di altri testimoniano l'efficacia delle riflessioni elaborate nell'ambito di questa scuola di pensiero, in un confronto con la situazione attuale. Punto di partenza dell'analisi saranno siti istituzionali di musei italiani e stranieri e pagine

1 Nome adottato nel 1980 da Andrè Desvallèes. 
di social media con cui molti musei hanno tentato un nuovo e inesplorato rapporto con il pubblico. Verranno trattati esempi riferiti al Canada, ${ }^{2}$ forse la nazione più aggiornata e originale nel trattare con visitatori che, per vari motivi, non possono accedere al museo, ma anche esperienze condotte in Italia, che si è dimostrata altrettanto vitale in questa occasione.

\section{I musei sono fatti per il pubblico: l'attenzione del museo nei confronti dei visitatori}

Se la Nouvelle Muséologie chiederà, con insistenza, di avvicinare il pubblico in maniera nuova ai contenuti dei musei e alle opere d'arte, il lungo processo di modernizzazione era però iniziato almeno negli anni Trenta. Tappa fondamentale di questo percorso era stata la Conferenza di Madrid del 1934, dove vennero affrontate, per la prima volta in maniera organica, molte delle questioni relative alla valorizzazione delle opere d'arte, alle diverse modalità di presentazione delle collezioni, al valore educativo che il museo doveva assolvere, con una nuova attenzione verso il pubblico. ${ }^{3} \mathrm{Nel}$ clima di ricostruzione del dopoguerra il dibattito torna attuale e nel 1946 viene fondato, in seno all'UNESCO, il Consiglio Internazionale dei Musei (ICOM) che sostituiva l'Office International des Musées (OIM), assumendo fra i vari compiti anche quello di lavorare per il riconoscimento del ruolo sociale e della funzione del museo nella società moderna (Dragoni 2016). Qui si confronteranno due anime: quella statunitense, orientata da sempre verso il pubblico ${ }^{4}$ e quella francese, più legata a un'istituzione dal forte carattere nazionale ma in cui non mancarono attenzione e interesse per il ruolo sociale ed educativo. Negli anni Cinquanta, con i seminari internazionali di Parigi del 1951, di Brooklyn del 1952 e di Atene del 1954, organizzati in maniera congiunta da ICOM e UNESCO, il tema più diffuso sembrava essere, ancora una volta, quello della didattica museale, affinché la fruizione del patrimonio culturale non restasse limitato a una cerchia ristretta

2 Per una panoramica completa, non solo sul Canada, si veda la pagina del sito, in costante aggiornamento, del GOEMP (Group of Ontario Emerging Museum Professionals) dedicata ai musei e alla loro risorse durante il COVID-19: https://goemp.wordpress. com/resources/covid-19-resources/.

3 Come dimostrano gli atti pubblicati nel 1934 con il titolo Muséographie. Architecture et Aménagement des Musées d'Art.

4 Si cita ad esempio Laurence Vail Coleman, direttore dell'American Association of Museums che pubblica, già nel 1927, il Manual for Small Museums dove vengono proposte molte idee legate all'educazione museale che troveranno nuova vitalità negli anni Cinquanta, come laboratori didattici e mostre itineranti da portare nei quartieri cittadini socialmente depressi (Coleman 1927). Sul tema si veda Dragoni 2015, 154. Per una analisi sul pubblico nei musei americani si veda Hooper Greenhill 2006 e Dragoni 2016. 
di visitatori. All'incontro di Brooklyn su The Role of Museums in Education parteciparono centoventi responsabili museali provenienti da venticinque nazioni, che si confrontarono sulla necessità di superare la figura conservatrice del curator museale per allargarne la funzione in una prospettiva educativa e divulgativa (Damioli 2011, 12).

Ragionando, invece, sulla museologia nel nostro Paese almeno fino agli anni Settanta, ci si trova di fronte a un arcipelago frastagliato e ricco di considerazioni, con tendenze, spunti, teorie che incrociano e si sovrappongono ai risultati della più ordinata e sistematica ricerca di stampo anglofono o francofono. Al seminario di Parigi, per conto dell'Italia, parteciperà Giulio Carlo Argan che avrà l'occasione di denunciare il ritardo dei musei italiani quanto alla loro funzione educativa (Dragoni 2015, 151). Sin dai suoi esordi di funzionario, Argan aveva riconosciuto al museo il ruolo fondamentale di promotore della cultura, ${ }^{5}$ in quanto luogo deputato alla ricerca scientifica e all'organizzazione di attività didattiche (Contardi 1983). ${ }^{6}$ Per lo studioso il museo è il territorio della presa di coscienza del visitatore e luogo della memoria dei valori sui quali si riconosce una civiltà, all'interno del quale il cittadino poteva cercare la propria identità politica e culturale. Poiché il fine ultimo doveva essere quello di promuovere la crescita culturale della comunità, Argan sottolineava l'importanza di uno stretto collegamento, da un lato con l'università, ambito privilegiato della ricerca, dall'altro con il tessuto produttivo del Paese (Marrocco 2011).

Nel 1955, sulla scorta delle indicazioni emerse nelle precedenti riunioni, si aprì a Perugia il Primo Convegno Italiano di Museologia, organizzato dal Ministero della Pubblica Istruzione in collaborazione con l'Accademia Americana di Roma. Questa fu l'occasione per un confronto fra le esperienze museali italiane e quelle statunitensi con cui alcuni relatori, come Lionello Venturi ${ }^{7}$ e Fernanda Wittgens, ${ }^{8}$

5 Sul tema si veda anche Argan 2005; Gamba 2009; Pinelli 2012.

6 Sulla funzione educativa dei musei nel pensiero di Argan si veda, tra gli altri, De Carli 2003.

7 A lui si deve l'introduzione in Italia del concetto di 'museo-scuola', quale luogo di apprendimento del linguaggio artistico, secondo il modello del pedagogista filosofo John Dewey, che Venturi aveva conosciuto negli anni dell'esilio americano, seguendo da vicino anche le pratiche didattiche adottate dai musei americani nei confronti degli studenti. Sull'argomento esistono moltissimi studi anche piuttosto recenti. Si veda, tra gli altri, Lollobrigida 2010 e Campolmi 2011.

8 Fernanda Wittgens fu una delle donne pioniere della didattica museale in Italia alla quale si deve il concetto di 'museo vivo' ripreso poi dal suo successore nella direzione della Pinacoteca Brera, Franco Russoli. Sarà tra le prime direttrici museali a comprendere il carattere innovativo dei musei americani e il ruolo divulgativo che potevano avere i mass media in un contatto costante con le istituzioni locali, sia pure con un atteggiamento prudente di critica nei confronti della promozione e della comunicazione che si poteva fare attraverso la televisione e la radio. Si veda anche il suo intervento al Convegno di Perugia nel 1955 (Wittgens 1956). 
erano già entrati in contatto diretto. Nel 1956, l'Italia aderisce alla Campagna Internazionale dei Musei, promossa dall'UNESCO per celebrare i suoi primi dieci anni di vita, nell'ambito della quale, dal 6 al 14 ottobre, viene istituita la Settimana dei Musei. Questa iniziativa, volta ad avvicinare i cittadini alle strutture museali, riscuote un enorme successo e verrà ripetuta, con formule diverse, negli anni seguenti (Gremigni 2001). Nel 1960 l’Italia accoglie le Recommandation dell'UNESCO ${ }^{9}$ che chiedevano di rendere i musei accessibili a tutti mediante ingressi gratuiti o a prezzi ridotti, aperture serali per i lavoratori, didascalie più chiare, guide cartacee e visite guidate commisurate alle differenti categorie di visitatori e affidate a personale qualificato. In questa direzione, il Ministero della Pubblica Istruzione per stabilire un contatto più stretto con le istituzioni scolastiche emana la Circolare 5324/4/Bo del 12 settembre 1960, in cui si dava disposizione ai Capi degli istituti di secondo grado affinché promuovessero delle visite guidate presso musei e gallerie con «l'utilizzo di persone particolarmente competenti e idonee, che potessero interessare gli alunni con delle lezioni illustrative» (Damioli 2011, 14). Nel 1969, in occasione del Convegno nazionale di Reggio Calabria promosso dall'Associazione degli Amici dei Musei sul tema I Musei nella società di oggi, Paola Della Pergola, direttrice della Galleria Borghese, convinta sostenitrice di un modello di educazione museale vicino al mondo della scuola, annunciava la costituzione, nell'ambito del Ministero della Pubblica Istruzione, di una commissione di studio per la didattica dei musei e così scriveva:

Dopo il 1945 un pubblico diverso per numero e qualità ha cominciato a frequentare il museo, si sentiva l'esigenza di adeguare il museo alla necessità di accogliere un pubblico tanto più numeroso, meno culturalmente preparato, ma difficile proprio per la sua stessa semplicità. (Della Pergola 1980, 87)

Se questi furono gli importanti precedenti, fu sicuramente il convegno romano Il museo come esperienza sociale, nel dicembre del 1971, a unire in maniera indissolubile il tema della tutela con quello dell'uso socioculturale e educativo delle strutture museali. Tra i partecipanti anche Franco Russoli che ribadirà la necessità di avvicinarsi al pubblico, con una particolare attenzione per quello socialmente e culturalmente meno dotato, considerando il museo non come

luogo privilegiato di meraviglie e di evasivi godimenti, ma, come luogo dove si va per alimentare i propri problemi di conoscenza,

9 Pubblicate come Actes de la Conférence dell'XI sessione che si tenne a Parigi nel 1960. 
più che per subire alienanti e coercitive lezioni. (Russoli [1981] 2012, 222)

Nel 1973, sempre Russoli, futuro soprintendente di Brera e direttore de L'arte moderna, una delle prime pubblicazioni in fascicoli a carattere divulgativo, per partecipare attivamente al rinnovamento dei musei italiani e della museologia crea Museo Vivo, con un comitato di lavoro che coinvolse importanti studiosi e intellettuali, quali Gillo Dorfles, Tomas Maldonado, Bruno Munari e Roberto Guiducci. In un verbale delle riunioni del gruppo, datato 17 novembre 1975, Russoli denunciava ancora lo stato di arretratezza del museo italiano, ritenuto elitario, soprattutto se confrontato con quanto avveniva a livello internazionale:

può diventare strumento di comunicazione di massa solo se diventa attività. I musei che hanno un patrimonio da conservare dovrebbero farlo diventare immediatamente un patrimonio da fruire in maniera diversa. In Francia si fa lo stesso discorso col problema del Centre Beaubourg Pompidou che si pone come museo e si trova nella stessa difficoltà di essere nel futuro uno strumento reale di educazione di massa, poiché Parigi è un posto nel quale la massa va al museo, esattamente come ad Amsterdam, ma appena ci si trova in un luogo dove tale tipo di uso del museo non esiste, il discorso cambia. ${ }^{10}$

Benché lontani dagli esiti più dirompenti che ebbero in Francia e in Canada le proposte della nuova museologia, anche in Italia l'attenzione per un nuovo ruolo assunse una maggiore rilevanza con l'istituzione a Pisa, nel 1967, della prima cattedra di Museologia, affidata a Carlo Ludovico Ragghianti. Da quel momento in poi, sempre più intensi saranno i contributi teorici verso questa disciplina ${ }^{11}$ tanto che, nel 1972, Ragghianti costituirà anche un Centro per la Museologia e pubblicherà la rivista Museografia, attiva fino al $1985 .{ }^{12}$

10 Il testo si trova nell'Archivio di Franco Russoli, nel faldone personale della corrispondenza con Carlo Ludovico Ragghianti e Bruno Molajoli che Bernardi $(2017,149)$ ha studiato e catalogato.

11 Al dibattito sul ruolo sociale del museo si collegano anche le vicende storiche e legislative che si sono susseguite dalla metà degli anni Sessanta con i lavori della Commissione Franceschini fino alla costituzione, nel 1975, del Ministero per i Beni Culturali e Ambientali.

12 La rivista è stata pubblicata nella collana «Musei. Meraviglie d'Italia». 


\section{$3 \quad$ La Nouvelle Muséologie}

Se ci spostiamo nella Francia della fine degli anni Sessanta, sebbene questa fosse tra le nazioni più aggiornate e attive in tema di partecipazione e di coinvolgimento del pubblico, si assiste alla definizione di una nuova identità culturale dei musei, che nasceva da un evento - per certi versi altrettanto traumatico come la pandemia del COVID-19 - che fu la contestazione giovanile del '68. Il museo che in Italia non era stato travolto dalle proteste perché, affermava Luciano Berti, era considerato tra le strutture «assenti dalla realtà» (Cresti 1976, 84), inesistente e quindi da non frequentare, in Francia si trasformò in uno dei luoghi in cui le ideologie sessantottine trovarono un terreno fertile per molte sperimentazioni e proposte innovative. Secondo Pierre Gaudibert, ad esempio, all'interno dei musei, in particolare quelli dedicati all'arte contemporanea, si doveva cambiare la stessa struttura espositiva per sostituirla con una piattaforma aperta e accogliente, per la diffusione di tutte le forme d'arte che non trovavano spazio in altri contesti (Rigolo 2009, 15). Anche i curatori dovevano avere la moderna funzione di animateurs, questione che tendeva a spostare l'attenzione sull'aspetto sociale, politico e sulla capacità di creare validi e articolati rapporti con un pubblico sempre più partecipe e attivo (Rigolo 2009, 15). Gaudibert invitava a utilizzare i finanziamenti pubblici non per accrescere le collezioni permanenti, ma per produrre opere che si presentassero come un evento o uno spettacolo, effimere e distruttibili, ma molto coinvolgenti per gli spettatori (Pavis 1971). Le proposte di Gaudibert si caratterizzavano, inoltre, per uno spiccato carattere politico, con riferimenti sociologici alle riflessioni di Louis Althusser e di Pierre Bourdieu. I musei dovevano diventare, in rapporto al contesto politico della Francia degli anni Sessanta, luoghi chiusi di una nuova utopia attiva (Pavis 1971), delle 'isole di libertà' dove la censura politica e culturale poteva essere minore rispetto al mondo esterno, inteso quale spazio incandescente della strada e delle piazze in rivolta, dove le opere d'arte potevano liberare il loro potenziale esplosivo, per agire sull'immaginario e la sensibilità dei visitatori, «mettendo in discussione abitudini e certezze» (Rigolo 2009, 16).

Con queste prospettive Gaudibert realizzò, fin dal 1967, nel Musée d'Art Moderne di Parigi da lui diretto una nuova sezione chiamata «Animazione-Ricerca-Confronto» (ARC), dedicata alle nuove tendenze sperimentali dell'arte figurativa, della musica, del teatro e, successivamente, della fotografia e del cinema. L'attività dell'ARC fu davvero frenetica: in cinque anni furono organizzate più di cento mostre ed eventi (Gaudibert 1970). Gaudibert coinvolse anche gli studenti della sua cattedra di Storia dell'arte contemporanea nel redigere le note informative che venivano distribuite al pubblico all'entrata di ogni mostra. Gli stessi studenti organizzarono conferenze e semina- 
ri e incrementarono l'attività didattica con laboratori per l'infanzia (Gaudibert 1970). Oltre agli spazi per le esposizioni venne allestita una sala polivalente con sedute e palco mobili per concerti e spettacoli. Tutti gli eventi che ospitava erano caratterizzati da un alto grado di sperimentazione, come gli spettacoli di danza contemporanea, in cui i ballerini si muovevano nelle sale interagendo con le opere, le passeggiate-concerto, con piccole orchestre che accompagnavano i visitatori, e gli spettacoli di luce all'esterno, che amplificavano il contatto con il territorio circostante. Seguendo l'esempio della Francia, negli stessi anni, altre istituzioni iniziarono a dimostrare interesse verso ulteriori aspetti dell'arte contemporanea, più vicini alle arti performative e basati sul coinvolgimento del pubblico: il Kunsthalle di Berna, il Modern Museet di Stoccolma e lo Stedelijk Museum di Amsterdam. In Italia, fu soprattutto la Galleria Nazionale d'Arte Moderna di Roma a proporre un nuovo modo di vivere il museo, grazie alle iniziative organizzate da Palma Bucarelli, dal 1968 in poi, con spettacoli teatrali di grande risonanza come la Gallinella Acquatica di Tadeusz Kantor, ${ }^{13}$ la musica sperimentale di Nuova Consonanza, le conferenze spettacolo di Enzo Mari. Durante la direzione di Giorgio de Marchis, dal 1979 al 1981, fu creato anche un Dipartimento delle Arti Performative, diretto da Ida Panicelli ${ }^{14}$ e dal critico teatrale Giuseppe Bartolucci, che invitarono nella Galleria tutti i gruppi più importanti delle diverse avanguardie sperimentali, da quelle teatrali del Beat '72, de La Gaia Scienza, di Mario Martone con Falso Movimento, a quelli di musica elettronica, alla danza moderna di Elisa Piperno, al teatro butoh della compagnia Sankai Juki.

A partire dal momento in cui i giovani rivendicavano il potere rivoluzionario dell'immaginazione, nuove forme di partecipazione alla vita culturale e uno svecchiamento di tutte le istituzioni preposte alla formazione, da struttura assente il museo adotterà ogni strategia per diventare struttura aperta, reclamando una dimensione sociale, un carattere interdisciplinare e una necessaria apertura al territorio. Dal museo degli oggetti e delle collezioni, si passerà al 'museo delle idee', luogo di massima apertura al pubblico e al dibattito su questioni sociali, politiche e morali. Nasce dalla contestazione politica e culturale anche il 'museo forum', secondo la fortunata formula di Duncan Cameron.

In questo mio contributo, il richiamo quasi esclusivo alle sue teorie è legato al fatto che il Canada è stata una delle nazioni pionie-

13 Questa fu la prima volta in cui la produzione di Kantor fu presentata in Italia, grazie all'intervento di Achille Perilli che sollecitò gli organizzatori del Premio Roma, convinto della validità e novità di un'artista poliedrico quale Tadeusz Kantor. Per l'occasione il Salone centrale della Galleria fu trasformato in palcoscenico in cui gli attori si esibivano circondati dal pubblico che partecipava all'evento come se non si trattasse di una finzione teatrale ma di una scena reale.

14 Storica dell'arte interna alla Galleria. 
re nel considerare il museo come un luogo di incontro e che, in tempi più recenti, è stata una delle prime a utilizzare la rete di Internet quale primario strumento di comunicazione museale (Sassi Merien 2007, 10). Si può sostenere, anche, guardando alla storia della museologia, che in Canada i programmi educativi di maggior successo hanno avuto fin dal principio le loro fondamenta nella profonda comprensione delle esigenze e delle motivazioni del pubblico, unitamente all'autentico impegno per la partecipazione comunitaria (Sasha Piccato 2020, 159).

Le riflessioni di Cameron, ormai storicizzate in un tempo che sembrava appartenere al passato, sono tornate davvero molto attuali e hanno dimostrato come la natura stessa dei musei sia intimamente connessa alla necessità di essere, o diventare, dei luoghi simbolici e di riferimento per le comunità locali. Egli è stato sicuramente uno dei più lucidi studiosi della museografia nel nostro secolo, iniziando la sua carriera, nel 1956, presso il Royal Ontario Museum, dove ha lavorato da curatore sotto la stretta guida di Theodore Allen Heinrich. Particolarmente noto per il suo articolo «The Museum: A Temple or the Forum» (Cameron 1971), è considerato uno dei fondatori della Nouvelle Muséologie insieme a Georges-Henri Riviere e Hugues de Varine, John Kinard e Mario Vasquez, i quali, accanto alle riflessioni di Jean Baudrillard e Bernarde Deloche, fornirono una poderosa critica all'istituzione museale, suggerendo nuove formule per trasformare i musei in spazi vitali al servizio del pubblico.

Questa fase della museologia internazionale su cui esistono moltissimi studi, più o meno recenti, che sarebbe davvero difficile citare, mi sembra più che mai attuale in un momento in cui ampie fasce di visitatori si avvicinano a questi luoghi con rinnovato interesse, soprattutto dopo la prima lunga fase di chiusura nella primavera del 2020. Vorrei dire che torna a prendere forma lo spazio del forum dove il pubblico poteva assumere un comportamento attivo, rispetto al comportamento passivo che si teneva nello spazio destinato alle collezioni. Infatti, l'aspetto partecipativo era così sostanziale che lo stesso Cameron pensava fosse opportuno distinguere nettamente, dal punto di vista strutturale, il museo dal forum, sebbene queste due realtà potessero condividere lo stesso edificio e lo stesso tipo di pubblico. La divisione quasi fisica si rendeva necessaria in quanto si puntava su finalità molto diverse: nel museo si faceva educazione nel senso più tradizionale, mentre il forum era uno spazio aperto alla propaganda politica e alla discussione critica (Cameron 1971). Non una scelta antagonista, dunque, ma un'equilibrata coesistenza: se il forum poteva agire quale quella che oggi chiameremmo una piattaforma del benessere esperienziale in grado di facilitare relazioni interpersonali, il museo poteva operare da 'tempio', incorporando le collezioni, sia quelle legate alla tradizione che quelle che si presentavano quali manifestazioni del cambiamento: «the museum must build 
the collections that will tell us tomorrow who we are and how we got there. After all, that's what museums are all about» (Cameron 1971, 24). Questa distinzione può ancora oggi essere molto attuale, sostituendo alla parola 'forum' quella di 'museo digitale', inteso non quale surrogato del museo reale, ma come uno spazio diverso, aperto a tutti i tipi di pubblico e basato sulla condivisione.

La nuova forma proposta da Duncan Cameron partiva, come sarà per il sociologo francese Pierre Bourdieu, dalla questione del pubblico che non frequentava i musei e che pertanto, soprattutto in un paese vasto e culturalmente giovane come il Canada, era escluso da ogni forma di educazione artistica. I risultati di una ricerca condotta a Toronto nel 1961 mostravano, infatti, una grande correlazione tra livello culturale elevato e la tipologia dei visitatori dei musei. ${ }^{15}$ Poiché chi non aveva nessuna forma d'istruzione si autoescludeva dalla partecipazione attiva, ciò che si richiedeva erano soprattutto delle nuove strategie educative che riguardassero la comunicazione museale e il buon uso dei mass media nella divulgazione. Le stesse esposizioni museali dovevano essere concepite, fin dall'inizio, in modo da fornire spunti per programmi televisivi, film, articoli su riviste specializzate.

Similarly the relatively unprogrammed and often unexpected events in the forum must be transmitted through the mass media. The public forum must be integrated into the circuits of electronic communication networks if it is to be significant in society. It must not be confused with the "forums" created by these networks. (Cameron 1971, 23)

Lo studio del museologo canadese, fondamentale nello stimolare la creazione di luoghi più partecipativi, ha contribuito in maniera determinante a porre l'attenzione sul rapporto tra il pubblico e i curatori, indicando nell'adozione di linguaggi più comunicativi la soluzione per valorizzare le collezioni e per una maggiore considerazione del visitatore (Sassi Merien 2007, 29). Fu certamente la rinnovata capacità comunicativa dei musei più illuminati, come quelli canadesi, che portarono l'ambiente museale a diventare, negli anni Settanta, «una stimolante alternativa all'educazione convenzionale» (Screven 1969,7$),{ }^{16}$ dove si tendeva a rimarcare il potenziale esplorativo e si invitava il pubblico a praticare comportamenti di perlustrazione e investigazione, che fino ad allora erano stati estranei alla visita. Nell'esposizione e nelle sale si cercava di creare un'atmosfera di attesa per qualcosa che accadesse in maniera non controllata, casuale, per lo più sconosciuta allo stesso curatore. Questo atteggiamento 
ebbe una maggior presa presso i giovani che, abituati all'ordinarietà del sistema scolastico e del museo tradizionale, ne subirono maggiormente il fascino.

In ambito europeo, la nona conferenza generale dell'ICOM a Grenoble nel 1971, intitolata Le musée au service de l'homme aujourd'hui et demain, segna il momento in cui viene esaminato in maniera strutturale e operativo un nuovo assetto museale che realizzi contatti costanti e significativi con le comunità locali. Venivano citati come esempi positivi di contatto con il pubblico l'Anacostia Neighborhood Museum di Washington di John Kinard ${ }^{17}$ e il costituendo 'ecomuseo', ${ }^{18}$ proposto da George Henri Rivière e Hugues de Varine-Bohan, che traeva ispirazione dal museo aperto di tipo scandinavo. Nel museo di quartiere Anacostia si contrapponeva alla funzione istituzionale di conservazione delle opere uno spazio privo di collezioni, caratterizzato dal contatto con la comunità locale, coinvolta pienamente nell'attività espositiva e in quella educativa (Ribaldi 2005). Nel museo ecologico francese, invece, si faceva riferimento non tanto a un quartiere degradato, ma a un territorio antropizzato dove convivevano uomo, natura e cultura, facendolo diventare un luogo di sperimentazione, di ricerca scientifica ma, soprattutto, di presa di coscienza per la popolazione locale.

Le riflessioni teoriche della Nouvelle Muséologie, iniziate con gli aspetti legati alla politica coloniale, si erano poi allargate a tutti gli oggetti museali, al carattere e alla natura delle collezioni e alla loro validità in quanto portatrici di valori e di identità. In questo senso, fondamentali furono gli studi di Jean Baudrillard sul sistema degli oggetti museali che avevano una funzione attiva solo fuori dal contesto museale, ma una volta introdotti nelle collezione divenivano astratti, morti e chiusi in sé stessi; la dinamica della musealizzazione mostrava, secondo Baudrillard, fin dall'inizio, una sua ambiguità perché gli oggetti, al di là della loro praticità, erano posseduti per ragioni puramente soggettive (Baudrillard 2003). Sulla dicotomia tra l'oggetto e

17 Creato nel 1967 nel ghetto nero di Anacostia, da dove lo stesso Kinard proveniva, aveva l'obiettivo di sfidare i pregiudizi razziali, affrontando problematiche complesse quali la bassa scolarizzazione, la droga, la disoccupazione. Il progetto era sovvenzionato dalla Smithsonian Institution di Washington e partiva dall'idea di fare un museo dal basso coinvolgendo associazioni civiche e religiose, gruppi giovanili, inquilini, scuole pubbliche, polizia e clero (Kinard 2005, 69-71).

18 Gli ecomusei che partivano dalla prospettiva antropologica di Claude Lévi-Strauss sono la creazione più tipica della Nouvelle Muséologie. Il termine è stato coniato dallo stesso H. de Varine-Bohan e si riferisce, già dal 1968, al parco regionale naturale di Ouessant, dove si era cominciato a sperimentare il collegamento, in chiave museologica, tra una comunità e il suo territorio, attraverso il racconto plurale delle storie della popolazione, dei procedimenti di lavoro e dell'evoluzione del territorio stesso. Tra gli ecomusei più accreditati l'Ecomusée de Le Creusot-Montceau-les-Mines, aperto al pubblico nel 1974 . 
lo sguardo del visitatore aveva indagato anche Bernard Deloche, individuando alla fine dell'Ottocento il momento in cui il museo aveva abbandonato la sua primaria funzione di un luogo finalizzato all'apprendimento del pubblico per cedere, anche a causa dell'atteggiamento di curatori gelosi, all'elitarismo nella comunicazione e nella partecipazione. Infatti, sebbene l'estetica hegeliana avesse per prima conferito un carattere sacro alle opere, che ne richiedeva un culto narcisistico e idolatrico, solo attraverso ciò che Deloche chiamava «l'ossessione del museo» (Sassi Merien 2007, 23) l'arte aveva veramente assunto un carattere sacro per pochi iniziati:

C'est bien par le musée que l'art a été promu au rang de chose sacrée, qu'il a cessé d'être un médium du culte pour devenir luimême l'objet du culte. (Deloche 1985, 13)

Si creava «uno spazio ieratico e mitico», dove il visitatore era visto con sospetto e messo all'angolo, mentre il carattere sacro era rafforzato dal silenzio che si doveva osservare al cospetto delle opere. Pur non parlando di una vera religione dell'arte, anche Duncan Cameron arriverà a comparare le funzioni del museo con quelle di una chiesa, intesa come un «luogo di esperienze intime e private» dedicato alla contemplazione, dove, in un certo senso, si aggiornava il culto delle reliquie. Nel testo dal titolo emblematico The Pilgrim and the Shrine: The Icon and the Oracle, Cameron (1995) rintracciava la nascita del museo nel bisogno umano di stabilire un ordine al caos, con la conseguente volontà di raccogliere, in un santuario, le reliquie dell'arte, della natura e della scienza. In questi luoghi nati per la conservazione, i visitatori, appunto come pellegrini, compivano il rito sacro della visita. Tuttavia, il dato interessante di questo articolo è aver posto l'accento sulla necessità umana di catalogare per comprendere e dare valore a un'esperienza, elemento che, come dirò in seguito, è stato fondamentale anche per l'interazione tra il museo e le comunità 'travolte' dall'emergenza sanitaria del Coronavirus.

Nell'ambito della Nouvelle Muséologie, il sociologo più critico nei confronti dei musei tradizionali era stato Pierre Bourdieu, che con il suo famoso libro L'amour de l'art dans les musées européens diffonderà in ambito internazionale la questione della comunicazione e della desacralizzazione dello spazio museale. Fin dalle prime pagine del testo il museo viene descritto come il luogo dove si pratica una «religion de l'art» (Bourdieu, Darbel 1969, 13), un culto artistico per pochi, in cui la conoscenza viene elargita sotto forma di grazia, amplificata, come per Deloche, dal silenzio richiesto al visitatore. Questa soggezione sacrale era tanto più criticabile perché autoescludeva le classi meno dotate di strumenti culturali, come dimostrava il fatto che «la fréquentation des musées est presque exclusivement le fait des classes cultivées» (Bourdieu, Darbel 1969, 35). 
Recuperando alla memoria codeste riflessioni sul carattere sacro dei musei e sulla difficoltà di accesso di chi non possedeva codici adeguati, che la Nouvelle Muséologie aveva fortemente evidenziato negli anni più duri della contestazione al sistema, ancora oggi si può comprendere l'importanza della partecipazione emotiva del pubblico, dimostrata in questo frangente drammatico attraverso i social media. Grazie alla condivisione di sistemi iconici e di codici comunicativi, messi a disposizione da Instagram o da Facebook, il visitatore è stato in grado di assegnare un diverso portato evocativo e informativo agli oggetti presenti delle collezioni, spesso scoprendo delle opere o dei musei che non aveva mai frequentato prima. Il desiderio di condividere o semplicemente di partecipare, in un momento in cui per la prima volta si era impossibilitati a ogni tipo di contatto, è stato un ottimo movente per interessarsi dell'arte e della cultura. Sebbene tale stimolo, come dirò in seguito, non è sufficiente a produrre un bisogno formativo profondo può essere, tuttavia, considerato un fattore determinante per indirizzare i musei verso un nuovo umanesimo.

Infine, sia pur brevemente, vorrei accennare a quello che è stato il simbolo del cambiamento imposto dalla Nouvelle Museologie: il Centre Georges Pompidou. Inaugurato nel 1977, emblema del museo moderno in cui si ricercava un alto potenziale partecipativo, capace di sollecitare un 'consumo attivo' da parte dei visitatori, era stato promosso dalla destra di Chirac ma fu accolto con grande interesse anche dalla sinistra francese in quanto tentava un connubio tra il museo europeo e quello americano, «in un'originale sintesi tra l'alloro napoleonico e il computer dell'IBM» (Binni, Pinna 1989, 72). L'edificio, opera di Renzo Piano e Richard Rogers, a metà tra macchina futurista e quella tecnologica, appare una commistione di gallerie e di spazi espositivi, a cui si aggiungono un cinema, un ristorante, una biblioteca, un laboratorio didattico e una mediateca. ${ }^{19} \mathrm{Il}$ primo direttore Pontus Hulten, con il suo ideale di condivisione dei linguaggi dell'arte contemporanea, voleva far diventare questo il «luogo di un'esperienza» in cui il pubblico partecipasse al processo di produzione e di appropriazione della cultura. In questo grande contenitore, come era stato per il MoMA negli anni Trenta, si offriva soprattutto un'esperienza, un modello sociale e culturale, in cui il visitatore andava perché sentiva di far parte di un gruppo, anzi di una vera élite intellettuale. Pur nei suoi aspetti contraddittori, messi in evidenza soprattutto da Jean Baudrillard (1977), il Centre Georges Pompidou sarà lo spartiacque tra il passato dei musei e il presente, anche quello più attuale, passando in via definitiva da una serie di stanze

19 Il Centro comprende la Bibliothèque publique d'information, il Musée national d'art moderne, e IRCAM, un centro per la musica e le ricerche acustiche. All'interno dell'edificio è collocato, inoltre, il Centro del design industriale. 
chiuse, destinate a un ristretto numero di persone, alla piazza, luogo aperto, di tutti, dove avviene uno scambio di esperienze. Secondo Giovanni Pinna (Binni, Pinna 1989, 72), infatti, non era stata tanto l'architettura ma le scelte del suo direttivo ad avere determinato un positivo 'effetto Beaubourg', essendo stato tra i primi musei a riconoscere il ruolo centrale del pubblico. Dotandosi precocemente di strutture e personale dedicati all'educazione, con laboratori didattici di grandissime dimensioni e un programma pedagogico di conoscenza di tutte le forme d'arte, dalla pittura al cinema, aveva fornito prospettive multiple per i contenuti delle collezioni. Proponendo differenti percorsi tematici, con un'inversione di tendenza rispetto al modello dominante del MoMA, che aveva sempre rigorosamente privilegiato la narrazione lineare, il Centre Pompidou aveva inaugurato l'idea di uno spazio accogliente, eclettico e pluridisciplinare, in cui il pubblico poteva partecipare e vivere qualcosa di assolutamente nuovo. Ciò ha portato a un'evoluzione degli spazi, degli apparati espositivi e didattici che non posso trattare in questo contesto ma che hanno radicalmente modificato i comportamenti dei visitatori (Zuliani 2009).

\section{Le questioni che il museo deve affrontare oggi}

Le istituzioni museali hanno perso in questi mesi moltissimi visitatori, costituiti, prima della pandemia, per più del $50 \%$ da turisti e che oggi, per motivi di sicurezza e divieti di spostamenti, non possono più fisicamente accedere al museo. In questo nuovo scenario, si deve tornare a fare i conti con un pubblico di prossimità e con quello potenziale che apparentemente non è interessato all'esperienza della visita museale, ma vuole trovare nuovi spazi di aggregazione sia fisici che digitali. Se per molto tempo i musei si sono focalizzati sulle modalità di interazione e coinvolgimento di un pubblico ampio e diversificato, proponendo esperienze collettive al visitatore, ora devono sviluppare programmi e strutture che offrano, al contrario, un'esperienza spesso socialmente distanziata, isolata, per un ristretto numero di visitatori, ma che al tempo stesso resti formativa e di forte impatto esperienziale. Infine, data la difficoltà di raccogliere fondi e di attivare prestiti internazionali, per i maggiori costi di trasporto e di assicurazione, non soltanto per la mancanza di presenze tali da giustificare l'investimento, si dovranno sostituire le grandi mostre con esposizioni che aumentino la visibilità e l'importanza delle opere d'arte contenute nelle collezioni permanenti.

Se Duncan Cameron (1971) aveva teorizzato che i musei dovevano programmare iniziative di più vasta portata all'interno di programmi da esportare all'esterno dell'ambiente museale con lo scopo di raggiungere una platea ampia, allo stesso modo, Maurizio Vanni (Piraina, Vanni 2020, 91-5) sostiene che i musei del Duemila, soprattut- 
to quelli medio-piccoli, debbano progettare le loro attività con largo anticipo, sia dal punto di vista economico che di sostenibilità. Non si potrà più solo utilizzare la promozione tradizionale e il lavoro dell'ufficio stampa, ma ogni piano di comunicazione dovrà sempre essere preceduto da un progetto di marketing museale, anche digitale, che contempli strategie appropriate ai target d'interesse e sinergie con istituzioni nazionali e internazionali che abbiano scelto di intraprendere la strada della sostenibilità, soprattutto quella ambientale. I musei del futuro si troveranno di fronte pubblici che inseriranno la visita all'interno di una pianificazione molto attenta, spesso legata a una scelta motivata tra le moltissime proposte del mercato culturale. Anche per questo si dovranno tener presenti tutti gli aspetti etici e i nuovi principi di una museologia che guarda all'equità, alla solidarietà, alla responsabilità e all'interdisciplinarietà (Piraina, Vanni 2020, 91-5). Infatti, ciò che rende il dibattito sul ruolo sociale ancora attuale, come ha sottolineato in un'intervista Madeleine Grynsztejn, direttrice dell'MCA di Chicago, ${ }^{20}$ sono le modalità con cui i musei potranno tornare a essere un punto di riferimento per la collettività, rafforzando il tessuto sociale e rendendo il senso di appartenenza del visitatore un valore fondamentale. Il museo dovrà diventare, anche secondo Peter Keller, responsabile dell'ICOM, il luogo di condivisione delle storie locali, che non sono provinciali per il fatto di essere attinte da realtà conosciute e contingenti, in grado di attrarre il pubblico, sia pure in un mondo globalizzato, attraverso un interesse emotivo e partecipativo che non è un diversivo ma un momento di formazione culturale. Anche durante la chiusura dei musei la cultura, in ogni sua forma, ha dimostrato di avere un enorme impatto emozionale per le persone, rivelandosi capace di produrre interconnessione nella distanza e di creare un dialogo interculturale tra le varie parti del mondo.

Mentre le istituzioni museali di tutto il mondo sono state chiuse a causa del COVID-19, uno stratega culturale di grande capacità come András Szántó (2021) ha condotto una serie di interviste con ben ventotto direttori. ${ }^{21}$ Ciò che emerge da queste conversazioni è un ri-

20 Le sue riflessioni si possono leggere anche su Artnet: https://news.artnet.com/ opinion/madeleine-grynsztejn-mca-chicago-op-ed-1875996.

21 Conversazioni con: Marion Ackermann (Staatliche Kunstsammlungen Dresden), Cecilia Alemani (The High Line, New York), Anton Belov (Garage Museum of Contemporary Art, Moscow), Meriem Berrada (MACAAL, Marrakesh), Daniel Birnbaum (Acute Art, London), Thomas P. Campbell (Fine Arts Museums of San Francisco), Tania Coen-Uzzielli (Tel Aviv Museum of Art), Rhana Devenport (Art Gallery of South Australia, Adelaide), María Mercedes González (Museo de Arte Moderno de Medellín), Max Hollein (The Metropolitan Museum of Art, New York), Sandra Jackson-Dumont (Lucas Museum of Narrative Art, Los Angeles), Mami Kataoka (Mori Art Museum, Tokyo), Brian Kennedy (Peabody Essex Museum, Salem), Koyo Kouoh (Zeitz Museum of Contemporary Art Africa, Cape Town), Sonia Lawson (Palais de Lomé), Adam Levine (Toledo Mu- 
tratto composito di musei che lavorano per rendere le istituzioni più aperte, democratiche, inclusive, sperimentali ed esperienziali, tecnologicamente esperte, culturalmente polifoniche, in sintonia con le esigenze dei loro visitatori e delle comunità. In molti casi, soprattutto per i musei più moderni ed extraeuropei, si tratta di istituzioni progressiste che si considerano al centro delle loro comunità e società, in cui la pandemia ha funto da acceleratore a impulsi che erano già presenti. Tra i direttori che provengono da diversi contesti e da diverse generazioni, emerge ancora il riferimento al Centre Pompidou di Parigi, termine di paragone per il futuro, perché il Beaubourg è implacabilmente moderno, con un'idea radicalmente nuova di ciò che può essere, per come delinea il suo ruolo e per la sua particolare programmazione. Anche l'esperienza di alcuni musei asiatici, sostiene Szántó, può essere considerata un esempio particolarmente interessante, perché queste istituzioni non sono appesantite dal bagaglio storico e dalla memoria che pesa su quelle europee. Queste realtà museali sembrano essere più intraprendenti, disposte a infrangere le regole, pronte a sperimentare cose nuove, ad esempio 'disimparare' - concetto che compare spesso quale provocazione in molte delle interviste del libro - ossia avere una concezione meno elitaria del museo e dell'arte.

Tra gli elementi positivi e nell'ottimismo che si coglie in molti interventi sulle possibilità future, c'è anche un aspetto negativo che è emerso in questo tempo in cui è stato incrementato in maniera esponenziale il lavoro da remoto. Questa attività ha portato a un maggiore isolamento tra le persone, a una maggiore disuguaglianza tra le professioni, in termine di salute e sicurezza. Se il museo può cogliere nella tecnologia digitale una grande opportunità, deve porsi anche il problema di mitigare gli effetti negativi dell'uso prolungato dei devices digitali, soprattutto sulle generazioni più giovani. In questo senso, si devono favorire laboratori creativi in presenza e cercare di trasformare le istituzioni museali in luoghi sempre più aperti al contesto territoriale e cittadino. Per ridurre la nuova forma di isolamento sociale legata alla DAD, il Museo Marino Marini di Firenze, tra le due ondate della pandemia, ha deciso di aprire una nuova sezione, nel chiostro rinascimentale, dove saranno ospitati dei laboratori creativi, anche estivi, per i bambini più piccoli. L'idea di «Kinder

seum of Art), Victoria Noorthoorn (Museo de Arte Moderno de Buenos Aires), Hans Ulrich Obrist (Serpentine Galleries, London), Anne Pasternak (Brooklyn Museum), Adriano Pedrosa (MASP, São Paulo), Suhanya Raffel (M+ Museum, Hong Kong), Axel Rüger (Royal Academy of Arts, London), Katrina Sedgwick (Australian Center for the Moving Image, Melbourne), Franklin Sirmans (Pérez Art Museum Miami), Eugene Tan (National Gallery Singapore \& Singapore Art Museum), Philip Tinari (UCCA Center for Contemporary Art, Beijing), Marc-Olivier Wahler (Musée d'Art et d'Histoire, Geneva), and Marie-Cécile Zinsou (Musée de la Fondation Zinsou, Ouidah). 
art» nasce da esempi di musei del Nord Europa e, ancora una volta, dalla capacità di ascolto, spiega la presidente Patrizia Asproni, nel comprendere le difficoltà educative e relazionali di molte famiglie che abitano in un centro storico sempre più disabitato e che possono sentire il museo quale sostegno e luogo d'incontro accogliente, luminoso e creativo. ${ }^{22}$ Peter Grey (2015), autore del libro Lasciateli giocare, ha osservato come nella nostra società eccessivamente occupata e connessa il tempo del gioco si sia drasticamente ridotto, ostacolando l'apprendimento delle abilità dell'infanzia. Per questo si deve sviluppare anche nei musei un diverso modello educativo che sostenga la curiosità, la gioiosità e la capacità di socializzare.

Infine, tra gli aspetti negativi non si può dimenticare che le istituzioni pubbliche, chiuse per lunghi periodi, hanno subito un grave danno economico, questione che il museo digitale non potrà risolvere se non trovando una giusta mediazione con quello reale, tra ciò che si può proporre sul web e ciò che ha una sua validità solo nel contatto fisico con l'opera d'arte (Won-Joo 2020, 79).

\section{Senza limiti di tempo e di spazio il museo digitale è un luogo accogliente}

In occasione della chiusura forzata dei musei l'ICOM, che ha monitorato $^{23}$ l'impatto della crisi sul settore, ha reso pubbliche le soluzioni più creative ideate per raggiungere il pubblico e continuare a impegnarsi con le diverse comunità di riferimento. Diversi studiosi, pensando all'immenso museo virtuale che si offriva in questi mesi sui social e sui network, ad esempio su Sky Arte, hanno fatto riferimento al Musée imaginaire di Andrè Malraux, senza mura, esteso e infinito, fatto di sole riproduzioni fotografiche. Al contrario, ritengo che altri modelli, pur caduti nell'oblio negli anni Novanta, siano invece ancora più suggestivi. Le aperture straordinarie e gli orari prolungati erano considerati dai teorici della Nouvelle Muséologie delle condizioni necessarie per rendere questo luogo veramente sociale e accessibile a tutti, soprattutto alle classi lavoratrici. La Galleria Nazionale d'Arte Moderna di Roma, già negli anni Cinquanta, fu tra i primi musei in Italia insieme alla Pinacoteca di Brera ad adottare delle aperture serali per venire incontro alle esigenze dei lavoratori e degli studenti. Mentre a Milano il rapporto stretto con la realtà in-

22 Descrizione dell'esperienzadilaboratorio: https://agcult.it/a/37204/2021-05-06/ imparare-l-arte-attraverso-il-gioco-il-museo-marino-marini-di-firenzelancia-il-concept-kinder-art.

23 Si veda un'ampia panoramica: https://icom.museum/en/news/museums-and-covid-19-8-steps-to-support-community-resilience/. 
dustriale e le scuole professionali aveva spostato l'interesse soprattutto verso la formazione della classe operaia, a Roma, dove del resto poche erano le industrie, sono stati soprattutto i giovani, ancora prima della mitica Estate romana ideata da Renato Nicolini, ad affollare le sale della Galleria Nazionale d'Arte Moderna. Oggi, paradossalmente, in tempi di chiusura forzata, i musei hanno sperimentato il valore aggiunto dato dall'accesso illimitato ai contenuti. In tal modo il museo è stato percepito come un luogo senza limiti di spazio, di tempo e di condizione sociale, con cui poter interagire in ogni momento attraverso la tecnologia informatica. Pur non entrando nel merito delle differenze sulla presenza dei musei sui social network (Facebook, Instagram, ecc. rispetto a quelli istituzionali del Ministero), certamente le strategie utilizzate su queste piattaforme sono state di grande impatto, come dimostra uno dei più famosi motori di ricerca sull'arte, Google Art \& Culture, che ha subito una vera impennata nel marzo del 2020. Proprio come nei forum degli anni Settanta, le piattaforme social hanno trasformato i musei in nuovi luoghi d'incontro virtuale, sempre accessibili, in cui le persone si sono sentite accolte, chiedendo di partecipare per manifestare i propri sentimenti, esporre le proprie opinioni, mostrare la propria creatività. Il digitale ha fatto del museo uno spazio accogliente e inclusivo, abbattendo molti degli ostacoli creati dalla distanza e dalla mobilità, sebbene vadano ancora considerate le barriere tecnologiche ed economiche che sussistono in moltissime realtà nazionali e internazionali, come ricordano le Raccomandazioni UNESCO sulle risorse operative aperte (OER) del 2019. Queste limitazioni all'accesso possono essere superate solo se i materiali didattici messi a disposizione saranno realmente di dominio pubblico, liberi, adattati ai diversi contesti culturali e di apprendimento, riutilizzabili e condivisi da chi ha difficoltà economiche o bisogni educativi speciali. Certo, la visita al sito è altra cosa rispetto alla visita reale ma, citando Cameron, non dobbiamo pensare a una contrapposizione ma a una loro coesistenza. Anche rispetto alla soggezione psicologica che le istituzioni museali possono creare, la porta d'ingresso online si è dimostrata particolarmente accogliente, capace di mitigare e talvolta abbattere la soglia della paura che appartiene a un'ampia fascia di coloro che si autoescludono dalla visita museale. Come sostiene Elena Bonacini (2020), l'attività creativa che si sviluppa sui social è il primo presupposto per la costruzione del senso di appartenenza a un gruppo sociale, per la creazione d'identità condivise e per l'ampliamento del proprio orizzonte comunicazionale. L'alto grado di partecipazione è dato, infatti, dalla libertà che l'utente possiede, non solo di ritrovare i contenuti e di memorizzarli, ma di collaborare alla loro creazione e ri-creazione personale. La reciprocità con l'utenza e la co-produzione di contenuti culturali erano state adottate, prima della pandemia, più facilmente nei musei tecnico-scientifici, notoriamente più orienta- 
ti alla sperimentazione, piuttosto che nei musei tradizionali, mentre oggi tutti riconoscono l'importanza di una profonda interazione sociale che può avvenire attraverso le tecnologie digitali, di cui il web costituisce la risorsa più adatta.

Spesso economicamente e culturalmente meno dotati, alcuni tipi di pubblici mostrano difficoltà di accesso per via della posizione geografica, della progettazione spaziale e della collocazione delle opere, ostacoli sia fisici che psicologici che ancora oggi non sono stati totalmente abbattuti. Al contrario, con i social media, l'accesso illimitato ai contenuti museali e la libertà di seguire dei percorsi personali si sono dimostrati fondamentali per rendere la visita museale un'esperienza stabile e educativamente significativa. Infatti, in assenza di un modello istituzionale e di un percorso predefinito, il pubblico di Internet ha esibito prova di sapersi avvicinare alle opere d'arte in modo personale, partecipando alla realizzazione di tableau vivant, postando fotografie, pubblicando commenti ed esperienze. La programmazione virtuale si è dimostrata più coinvolgente per la popolazione demografica più giovane e digitalmente esperta, anche se non è mancata la partecipazione di un pubblico più adulto che spesso tende all'invecchiamento culturale e all'isolamento. Il museo digitale ha offerto straordinarie opportunità di riunire comunità e generazioni che difficilmente sarebbero state insieme in un contesto reale. Dall'impulso dato dalla crisi, i musei potranno ricostruire un legame specifico con le città, saranno un interfaccia tra passato, presente e futuro, un luogo dove familiarizzare con le tecnologie digitali, una sorta di rifugio intellettuale e artistico per tutte le età (Piraina, Vanni 2020, 149). Per Ludovico Solima:

è crollato un muro, durante questa quarantena ed è crollato in termini culturali, prima ancora che tecnologici. Me ne sono reso conto a più riprese, l'ultima volta quando ho tenuto una lezione di management per conto della fondazione Scuola Patrimonio davanti a 700 studenti collegati in streaming, un numero assolutamente impensabile prima della pandemia. Ciò dimostra che queste risorse offerte dalla tecnologia devono essere orientate sul fronte della domanda, escogitando ad esempio questionari per i non-utenti dei musei, così da capire come trasformarli in utenti. (Ferrio 2020, 29)

In un tale contesto, esattamente come affermava Cameron, sarà soprattutto la capacità di creare relazioni con il pubblico, ossia di avviare delle discussioni, lanciare delle proposte, farsi carico delle esigenze, che lo renderà un luogo veramente nuovo. Insomma, se molti musei si sono attivati con grande naturalezza, semplicemente cambiando la dimensione spaziale con quella digitale, si deve però comprendere che quest'ultima richiede competenza, risorse, infrastrutture adeguate, come giustamente avverte Maria Elena Colombo (2020), 
che non si improvvisano senza una riflessione più ampia nel prossimo futuro. Un'occasione così straordinariamente drammatica ha fatto finalmente comprendere che il museo è un'istituzione al servizio della società e che proprio in tale relazione risiede la sua ragion d'essere (Colombo 2020). Se la sua funzione si è assestata sulla condivisione dei messaggi social si dovrà, in futuro, riflettere sul web e sulla rete quali strumenti non superficiali di comunicazione, sulle caratteristiche di un luogo che al pari di quello fisico possiede infinite sfumature e valori. Dopo una prima fase di entusiasmo sperimentale, la museologia dovrebbe trovare un modo nuovo e più appropriato nel proporre i propri contenuti digitali, perché, come sostiene Nicolette Mandarano (2019), realizzare un sito e aprire un profilo social sono solo un primo passo per una valida comunicazione, ma si devono creare contenuti specifici che possano garantire un corretto posizionamento nel web: una nuova strategia umanistica e partecipativa in cui il museo si dovrà muovere attraverso un'attenta e originale programmazione dei suoi contenuti. Se nella prima parte del lockdown i siti dei musei sono stati usati da laboratori di buone pratiche per operare in modalità online, fra letture di libri, favole dedicate ai bambini, raccolta di narrazioni delle opere, nella fase di normalizzazione - spiega Federica Manoli, curatrice del Museo Poldi Pezzoli - queste sperimentazioni dovranno servire come casi di studio per mettere a punto un sistema integrato in cui le potenzialità di un museo, sia esso piccolo o grande, siano amplificate dall'uso delle tecnologie informatiche. Ad esempio, il sistema di prenotazione online può garantire accessi contingentati, con un afflusso di persone limitato, "come pretende non solo l'emergenza, ma anche la bellezza di un museo come questo» (Ferrio 2021, 29), ma si può, al tempo stesso, raddoppiare il numero di presenze, nell'ottica della massima accessibilità, attraverso il trasferimento di alcuni contenuti delle collezioni sulla piattaforma digitale.

\section{$6 \quad$ Le nuove motivazioni della visita}

Il museo postmoderno degli anni Novanta si era rivolto a un pubblico con dei bisogni piuttosto standardizzati, individuati attraverso indagini di mercato, che si sono rivelati spesso molto lontani dalle reali esigenze dei visitatori. La situazione di crisi ha creato una straordinaria occasione per avvicinarsi al pubblico attraverso una nuova idea di ascolto, simile a quella che Kinard individuava per il museo di quartiere: «La popolazione parla e discute, il museo è l'orecchio d'ascolto» (Kinard 2005, 69). Questo lungo periodo di chiusura ha mostrato che per il visitatore, anche in tempi di pandemia, la scelta di accedere a un luogo come il museo, nasce dalla necessità di soddisfare dei bisogni emotivi personali e unici, non sempre individuabili dalle indagini perché generati da una situazione esistenziale particolare e personale. 
L'assenza di pubblico è stata anche una grande occasione per fare delle sperimentazioni che potranno essere utili quando si tornerà alla normalità, sia sui dispositivi espositivi che su un nuovo storytelling delle collezioni basato sulla capacità di ascolto della comunità. L'impegno ideativo di questi mesi ha consentito di intercettare le particolari e uniche esigenze emotive generate dall'isolamento, a partire dalle persone annoiate a quelle che cercavano un arricchimento personale. Ancora più interessante l'attenzione per quelle persone che hanno visto nella visita virtuale un sollievo dall'ansia e una cura del disagio per la perdita della normalità. Non a caso, sono stati soprattutto i musei canadesi, che già nel 2018 avevano ufficializzato la museoterapia come cura prescrivibile dal medico (Cicchinè 2020, 49 ), ad aver proposto le iniziative più interessanti allo scopo di restare vicini alle comunità locali e di aiutare chi soffriva di un disagio psichico. Tra tutte le esperienze voglio citare il Museum AGNES di Kingston che ha ideato un programma di aiuto e supporto, chiamato Art Hive @Agnes, dove sono stati affrontati i temi del benessere psichico e della cura di sé, promuovendo uno spazio sicuro dal contagio e un senso di comunità creativa. Gli adulti, con l'aiuto di un arte terapeuta, sono stati invitati a esplorare, ognuno dalla propria casa, le capacità creative fornite dalle diverse tecniche artistiche e dalle esperienze di gioco. Che si trattasse di un reale sostegno psicologico è indicato non solo dal numero molto alto di partecipanti ma dalla scelta fatta dai responsabili del sito di fornire i numeri telefonici, sulla pagina di accesso ai laboratori, dei centri di aiuto e di ascolto a cui rivolgersi in caso di difficoltà. Tra i commenti postati si può leggere: «Art Hive è uno spazio confortevole dove puoi venire e rilassarti. Mi piace perché è molto inclusivo e tutte le abilità sono utilizzate per farti sentire bene». ${ }^{24}$ Con l'isolamento, la solitudine, l'ansia e lo stress in aumento, c'è stata una maggiore richiesta di attività terapeutiche affidate all'arte, afferma Shannon Brown, coordinatrice del progetto: «questi programmi hanno attirato centinaia di partecipanti, molti dei quali non hanno mai saputo che l'arte potesse far parte della loro vita»..$^{25}$

Anche in Italia, da tempo, alcuni musei si sono occupati del benessere psicofisico dei visitatori o delle possibilità terapeutiche legate alla visita museale. Ancora una volta voglio ricordare, quale lontano

24 Sul sito del museo della Queen's University di Kingston (Canada) si possono trovare molte testimonianze e diverse immagini su tale esperienza: https://agnes.queensu.ca/connect/news-and-stories/supporting-a-healthy-community-throughart-and-wellness/.

25 https://agnes.queensu.ca/connect/news-and-stories/supporting-a-healthy-community-through-art-and-wellness/. 
esempio, la performance Uomini e recinti ${ }^{26}$ alla Galleria Nazionale d'Arte Moderna dove, nel 1979, venne organizzata un'inedita visita guidata per i malati dell'Ospedale Psichiatrico di Santa Maria della Pietà. Si trattava di una forma di sensibilizzazione nei confronti della malattia mentale che aveva portato questa realtà dal silenzio degli ospedali alla ribalta della società. ${ }^{27}$ Molti musei si sono occupati negli ultimi anni di progetti di inclusione e di sostegno per i malati di Alzheimer, per i non udenti, per i disabili mentali, fino all'organizzazione di eventi legati alla pratica meditativa dello yoga. ${ }^{28} \mathrm{Nel} 2018$, nove musei del Polo Museale della Campania, tra cui il Museo e Real Bosco di Capodimonte, hanno ideato Lo Yoga per i Musei - I Musei per lo Yoga. I corsi, tutti gratuiti e aperti anche ai neofiti, invitavano i partecipanti a prendere consapevolezza degli influssi che uno spazio artistico può trasmettere a livello emotivo, sensoriale e persino fisico, trasformando il modo di avvicinarsi alle opere d'arte e creando un modello ambientale di interazione tra la collezione e gli altri visitatori. ${ }^{29}$ La museologia odierna, dunque, quasi riprendendo le indicazioni che venivano dalla Nouvelle Muséologie, dovrà saper ascoltare e interpretare i bisogni evidenziati dal pubblico, inserendo tra i suoi obiettivi quello di poter essere una piattaforma del benessere esperienziale (Piraina, Vanni 2020, 100), in grado di facilitare relazioni interpersonali. Dovrà puntare sulla qualità dell'ambiente con un vero marketing umanistico, trasversale e non convenzionale, basato su idee innovative e personalizzate che dovranno produrre dei coinvolgimenti emozionali e relazionali (Piraina, Vanni 2020, 53).

\section{$7 \quad$ Il ruolo sociale di cui i musei si sono riappropriati}

Il processo di democratizzazione della cultura degli anni Settanta aveva portato alla creazione di nuovi luoghi di esposizione dal forte impatto sociale. Nell'attuale situazione, dopo decenni in cui questo modello museale era stato in parte abbandonato in favore di nuovi musei blockbuster internazionali, le istituzioni hanno ritrovato una nuova consapevolezza operativa e una nuova capacità professionale di relazionarsi con il pubblico. Musei piccoli e grandi sono stati incredibilmente capaci di progettare, nei primi mesi della pandemia, even-

26 Si possono avere maggiori dettagli sulla performance-visita guidata in: http:// www.fabrizioborelli-imaging.it/maxxi-10-13-maggio-2018/.

27 Dopo l'approvazione dalla legge 180, conosciuta come Legge Basaglia.

28 Anche la Pinacoteca di Brera ha realizzato dei laboratori per i malati di Alzheimer, così come molti altri musei nel mondo, a partire dal MoMA.

29 Descrizione delle attività su https://vivere.yoga/quando-lo-yoga-incontralarte-nei-musei/. 
ti per aiutare le loro comunità ad affrontare la situazione speciale in cui noi tutti ci siamo trovati per la prima volta nella storia dell'umanità. Se l'immagine più manifesta è stata quella di presentare mostre temporanee e collezioni permanenti attraverso i social media, l'aspetto più interessante, sottolineato anche nel decalogo proposto dall'ICOM, è stato quello di monitorare e sostenere i gruppi sociali più vulnerabili. Ad esempio, abbiamo visto progetti speciali realizzati per aiutare economicamente i soggetti più colpiti: i senzatetto, le donne a rischio di violenza domestica, i bambini con difficoltà di accesso all'istruzione, i migranti, i rifugiati e le minoranze che hanno subito atti di xenofobia a causa della paura del contagio. ${ }^{30}$

Ma anche la presentazione di opere d'arte a un pubblico più vasto e in forme nuove può rappresentare un modo per sconfiggere i pregiudizi e la discriminazione attraverso una narrazione che renda consapevoli del valore di appartenenza dei beni culturali a una comunità multietnica. Già tra il 2018 e il 2019 gli Uffizi, su impulso del direttore Eike Schmidt, del dipartimento Mediazione Culturale del museo e di due figure esterne, Simona Bodo e Maria Grazia Panigada, hanno proposto un progetto intitolato Fabbriche di storia, realizzando delle narrazioni dei dipinti della collezione affidate a persone immigrate da tempo a Firenze. Ogni narrazione è stata poi consegnata a un attore, tra gli altri, Marco Paolini, Marco Baliani e Lella Costa, tradotta in inglese e nella lingua di chi raccontava, dall'arabo al cinese a un idioma del Benin. L'intenzione, spiega una delle curatrici,

era di mettere in relazione il museo con qualcuno che non fosse il turista frettoloso, con un pubblico più prossimo al museo, che vive nella stessa città, nello stesso quartiere o che nel caso di Fabiana lavora al museo, ma che paradossalmente non è il pubblico che frequenta il museo. Contemporaneamente, usando il metodo narrativo, si provava a sollecitare una visita meno sbrigativa, più consapevole, più stanziale, perché capace di produrre dentro di sé non banali analogie, ma risonanze inattese. (Ebani 2021)

Questo potrebbe essere uno dei modi con cui musei e siti monumentali, che guardano al dopo COVID-19, potranno recuperare la loro ragion d'essere, dopo anni in cui le performance sono state misurate principalmente conteggiando l'incremento dei visitatori. Se durante i mesi del confinamento si è ricorsi al digitale per tenere attivo un canale di comunicazione, tuttavia, occorre tornare al museo 'servizio

30 Molte iniziative in tal senso sono state elencate e documentate nel sito della NEMO (Rete delle organizzazioni museali europee): https://www.ne-mo.org/fileadmin/Dateien/public/NEMO_documents/Initiatives_of_museums_in_times_of_corona_4_20.pdf. 
pubblico', assecondando ed esaltando quanto prescritto già nel Codice dei beni culturali e del paesaggio del 2004. Il bagaglio di idee dell'associazione Patrimonio di storie, nata nel 2011 e patrocinata da Simona Bodo, Maria Grazia Panigada e Silvia Mascheroni può essere un punto di partenza per nuove sperimentazioni. Tra tutte quelle censite sul portale ${ }^{31}$ ricordo l'iniziativa Brera: un'altra storia (2013), curata dalle storiche dell'arte Emanuela Daffra e Paola Strada, dove otto visitatori provenienti da Bosnia, Brasile, Egitto, Filippine, Perù, Senegal e Ungheria, oltre a un italiano, proponevano una narrazione di un'opera da loro scelta. Secondo Silvia Mascheroni, è fondamentale il ruolo di mediazione culturale che i musei, con i loro repertori di storie, possono svolgere nei confronti dei cittadini stranieri, immigrati di prima e di seconda generazione. L'esperienza del narrare consente di formare 'comunità patrimoniali', come suggerisce la Convenzione di Faro del Consiglio d'Europa del 2005, promuovendo attività culturali contro il disagio sociale e la povertà educativa.

Tra le molte riflessioni in questa direzione, è degno di nota il recente contributo di Elisa Bonacini (2012) che riflette sui tanti modi di costruire una storia a partire da ciò che un museo custodisce, sottolineando le potenzialità virtuose delle nuove tecnologie, ma anche la capacità che un'istituzione culturale deve possedere per connettersi con i nuovi pubblici. Sulla stessa linea si colloca da tempo $\mathrm{Ar}$ cheostorie, il web magazine diretto dall'archeologa Cinzia Dal Maso. Tra le realtà museali più attive anche il Museo Civico Archeologico Etnologico di Modena che ha condotto diverse iniziative, ad esempio Choose the piece, del 2011, in cui era stato chiesto a sessanta studenti immigrati di adottare un pezzo custodito nel museo, che si è così trasformato da reperto archeologico in qualcosa di simbolico e contemporaneo, «rinegoziandone il valore con le storie di chi era arrivato in città da molto lontano». ${ }^{32}$ L'elenco potrebbe essere ancora più lungo ma quello che mi preme sottolineare è che questi progetti, già attivi prima della pandemia, devono diventare un modello portante perché la difesa delle minoranze e l'integrazione sociale può allargare i pubblici e trasformare il contesto museale in un mentoring sociale, come la scuola o la famiglia, insegnando i valori sociali di integrazione, di ascolto, insomma di democrazia. Del resto, anche prima della pandemia, alcuni tra i più importanti musei italiani hanno promosso attività per stabilire relazioni con le comunità di riferimento, segnando, in generale, un significativo passaggio da un'attenzione prioritaria centrata sull'incremento della fruizione e dell'accessibilità a un obiettivo di più vasta portata, che concerne la partecipazio-

31 Si veda una panoramica sull'esperienza partecipativa su: https://www.patrimoniodistorie.it/parlano-di-noi/.

32 Cristina Zanasi, responsabile del progetto. 
ne dei pubblici alla vita del museo, anche accogliendo nuove interpretazioni delle collezioni..$^{33}$

In Canada, il Museo dei Diritti Umani e il Museo dell'Immigrazione si sono da tempo assunti la responsabilità di creare individui sociali che condividano uno stesso storytelling, accompagnando le generazioni verso una certa armonia sociale (Piraina, Vanni 2020, 155).

Ciò che è stato prodotto durante la pandemia non è stato solo un sostegno materiale ma una dimostrazione, in un tempo di estrema solitudine ed emarginazione, delle ragioni che spiegano e sostengono la nostra identità culturale e sociale. Le caratteristiche fondamentali del museo, luogo della memoria e del dialogo, ne hanno fatto un'istituzione degna di fiducia. Realtà museali che avremmo considerato marginali, in termini di numeri e di marketing, come l'Aga Khan Museum di Toronto dedicato all'arte islamica, hanno invece avuto un fortissimo incremento di visualizzazioni nel periodo di lockdown. Attraverso le opere d'arte contenute nel museo, i concerti e le lezioni offerte online, le persone sono entrate in contatto con una tradizione culturale diversa che ha avuto il potere di farle sentire, in maniera consapevole, parte del mondo e di un'umanità condivisa. In Italia, Maria Fratelli, la direttrice di Casa Museo Boschi di Stefano (Milano), nel ricordare che i musei possano essere soprattutto luoghi fortemente presenti sul territorio e molto reali per le persone, ha visto nella pandemia l'occasione per

cambiare alcuni paradigmi che erano diventati veramente ossessivi: la frenesia dei numeri a discapito della registrazione della soddisfazione del visitatore, la necessità di dimostrare di avere tanto pubblico e riconoscimenti statistici immediati, rispetto all'evidenza di altri parametri di qualità: la capacità di costruire veramente archivi di conoscenza ed esperienza, la necessità di essere solidali e di condividere la cultura quale ausilio di salvezza, luce, corda, zattera, quello che poteva aiutare a non affogare nella solitudine e nella disperazione. ${ }^{34}$

33 Per cui si vedano le attività di ICOM Italia e della Commissione Educazione e Mediazione istituita nel 2007. Da ottobre 2020 è attivo il gruppo di lavoro Educazione al patrimonio culturale. Musei-scuole-territorio e professionalità, coordinato da Silvia Mascheroni, che sta affrontando le tematiche più urgenti sull'educazione al patrimonio, promuovendo, grazie ai Coordinamenti regionali, opportunità di incontro e confronto fra docenti e responsabili dei servizi educativi. Su alcune azioni che caratterizzano la professionalità dell'educatore museale, nonché sulle conoscenze e competenze ritenute utili e sul 'divario digitale' presente nel nostro Paese si veda il documento disponibile all'indirizzo http://www.icom-italia.org/wp-content/uploads/2021/01/ICOMItalia.GdLMuseiScuole.EducazionePatrimonio.7ottobre.2020.pdf.

34 Si veda il sito dell'ICOM Italia: http://www.icom-italia.org/tracciamo-larotta/. 
Altri aspetti fondamentali sono la conservazione e la creazione di un'identità collettiva nella quale la comunità si riflette. Se la necessità di conservare è all'origine stessa del museo, questa rappresenta, anche secondo Cameron (1995), un'esigenza universale e umana per dare significato a un'esperienza e averne consapevolezza.

Documentare ed esporre la crisi in atto non è solo servito a creare una memoria storica, ma ha significato mettere in grado le persone di comprenderla e di elaborarla. Ricordare e conservare le testimonianze e le modalità con cui le persone hanno affrontato il trauma della pandemia è stata un'ulteriore possibilità che i musei hanno avuto per avvicinarsi al pubblico, per dare un nuovo significato alle collezioni museali, preservando allo stesso tempo conoscenze e ricordi per le generazioni future. Ribadisce Katine Duhanal, curatrice del Canadian Museum for Human Rights che questa è stata un'occasione per capire ancora di più l'importanza delle storie orali, che devono essere conservate all'interno del museo accanto alle testimonianze materiali. ${ }^{35}$ La cultura orale tipica dei forum torna a essere un documento storico di straordinaria capacità evocativa e, se vogliamo, anche una novità a cui i musei potranno ricorrere sempre più spesso. La crisi sanitaria ha prodotto una enorme mole di documenti orali, dalle canzoni sui balconi alle dichiarazioni dei politici, dalle testimonianze dei medici a quelle delle persone comuni, che sono stati oggetto di raccolta di musei in ogni parte del mondo, soprattutto nei musei etnografici, scientifici e di storia locale. Dal Museo Etnografico Ambrosetti, in Argentina, che ha pubblicato online una mostra collettiva intitolata ExpoCuarentena ${ }^{36}$ al Canadian Museum for Human Rights che, in un momento di porte chiuse e distanziamento fisico, ha incoraggiato le persone a condividere le loro esperienze personali sulla pandemia, caricando brevi video di risposta a suggerimenti a tema (Remeir 2020). La prima delle domande è stata: «Quali atti di gentilezza ti hanno sollevato il morale durante la pandemia?» in modo da incoraggiare la produzione di storie personali ma anche di fornire un focus sulla compassione e sul senso di comunità, fondamentali per la difesa dei diritti umani. ${ }^{37}$ In Europa, il Museo di Erding in Baviera, fondato nel 1856 da un mastro calzolaio della zona con il compito di raccogliere, conservare e presenta-

35 Intervento online consultabile sul sito del museo: https://humanrights.ca/.

36 Tutta la mostra è consultabile online: https://issuu.com/etnoba/docs/expo_ cuarentena.

37 Certamente non è un caso che le manifestazioni contro il lockdown nazionale si siano svolte davanti al museo, luogo simbolo dei diritti umani ma anche protagonista delle attività di riflessione e confronto con il pubblico durante la pandemia. 
re la storia della città e della regione, ha sviluppato la sua attitudine istituzionale raccogliendo testimonianze, oggetti e fotografie della vita al tempo del Coronavirus. Nell'aprile 2020, il direttivo ha lanciato un appello pubblico per creare una Collezione Corona per le future generazioni, chiedendo l'aiuto dei cittadini che hanno risposto con grande entusiasmo. ${ }^{38}$ Vorrei sottolineare, come sosteneva Duncan Cameron, che tale vocazione non si può praticare solo nella contingenza ma deve essere programmata. Infatti, già dal 2015 il Museo di Erding ha assunto il ruolo di deposito culturale, grazie alle scelte museali del suo direttore, Harald Krause, che ha ampliato la gamma di visitatori e trasformato l'ampio ingresso del museo in un vero forum per il dialogo culturale.

In Italia, il primo Museo della Quarantena è nato da un progetto digitale del Museo Diocesano Tridentino di Trento, lanciato via web il 7 maggio 2020, sempre con la volontà di raccontare le lunghe settimane del lockdown attraverso gli oggetti-simbolo che ci hanno accompagnato. ${ }^{39}$ L'esposizione, in versione digitale, raccoglie le fotografie di oggetti di uso quotidiano - ma anche animali, piante, luoghi e cibi - che sono stati utili, consolatori, di conforto, di compagnia e, appunto, 'simbolici' della quarantena. Ogni immagine di questo museo digitale è contrassegnata da una breve didascalia indicante l'autore dell'oggetto scelto, la data di realizzazione, lo stato di conservazione e soprattutto il motivo della scelta, proprio per dare agli oggetti la stessa connotazione e classificazione che hanno le opere d'arte. La risposta è stata immediata, come racconta la direttrice Domenica Primerano, tanto che è stato creato un primo nucleo della raccolta, in continua espansione, dando vita a un grande contenitore narrativo, in grado di restituire al visitatore un quadro unico del lockdown e del ruolo centrale che determinati oggetti hanno avuto, nel tempo sospeso della nostra vita. Si tratta, quindi, non solo di recuperare il rapporto con il pubblico ma di 'invertire' lo sguardo dal museo verso i visitatori, trasformandoli in produttori di collezioni e di contenuti, per far emergere tematiche forti, spesso scomode, sull'esistenza e sulla vita della comunità (Primerano 2020, 224).

Tra i progetti più significativi, che hanno dato forza a quel ruolo sociale che il museo rivendicava già con la Nouvelle Muséologie, vanno ricordati quelli che, oltre a condividere la memoria, sono stati impegnati nell'elaborazione del lutto e nel senso di colpa che la pandemia da COVID-19 ha generato. Mi piace concludere con l'esperien-

38 Sul sito istituzionale è possibile vedere la parete fotografica realizzata nel foyer del Museum Erding con una piccola selezione della collezione Corona: http://www.museum-erding.de/index.php?id=67.

39 Si veda un esempio delle schede e degli oggetti scelti sul sito: https://www.museodiocesanotridentino.it/pagine/museo-della-quarantena. 
za Non recidere, forbice, quel volto, ${ }^{40}$ nata dalla collaborazione tra i professionisti dei servizi educativi ${ }^{41}$ della Galleria d'Arte Moderna e Contemporanea di Bergamo (GAMeC) e i mediatori umanitari della Caritas, in una città che, più di ogni altra, è divenuta un simbolo drammatico della pandemia. Ė stata questa un'occasione davvero unica, con un portato sociale di grande spessore, in cui il museo ha provato a spiegare le ragioni di un dramma vissuto dalle famiglie e dagli operatori sanitari. In un tempo di dolore e di sgomento, moltissime persone che dovevano elaborare il distacco dai propri cari, piene di sensi di colpa per non aver potuto dare l'ultimo saluto a chi moriva in ospedale, hanno trovato un luogo partecipativo per esorcizzare il dolore attraverso la condivisione. Il progetto, partendo dal verso di Montale Non recidere, forbice, quel volto, ha messo in atto un 'laboratorio di memoria generativa', con visite guidate e momenti di dialogo in cui il museo si è trovato davvero in ascolto della collettività, in una nuova forma di mediazione umanistica che non vuole sostituire la psicologia, ma rendere più facile l'incontro tra persone della stessa comunità. Si torna così al museo-forum, nella versione aggiornata dell'anno topico che è stato il 2020.

\section{Bibliografia}

Argan, G.C. (2005). Intervista sul Novecento. A cura di M. Perelman, A. Jaubert. Roma: Graffiti Editori, 18-19.

Contardi, B. (1983). «Premessa a Giulio Carlo Argan». Contardi, B. (a cura di), Storia dell'arte come storia della città. Roma: Editori Riuniti, 7-15

Baudrillard, J. (1977). Effett Beaubourg. Implosion et dissuasion. Paris: Editions Galilée.

Baudrillard, J. (2003). Il sistema degli oggetti. Milano: Bompiani.

Bernardi, E. (2017). Per un profilo intellettuale di Franco Russoli (1923-1977) [tesi di dottorato]. Venezia: Università Ca' Foscari Venezia.

Binni, L.; Pinna, G. (1989). Museo. Storia e funzioni di una macchina culturale dal '500 a oggi. Milano: Garzanti Editore.

Bonacini, E. (2012). «ll museo partecipativo sul web: forme di partecipazione dell'utente alla produzione culturale e alla creazione di valore culturale». Il capitale culturale. Studies on the Value of Cultural Heritage, 5, 93-125. http://dx.doi.org/10.13138/2039-2362/201.

Bonacini, E. (2020). I musei e le forme dello Storytelling digitale. Roma: Aracne.

40 Sul sito istituzionale è possibile leggere i modi e i tempi del progetto che si basa sulla mediazione umanistica tra persone: https://www.gamec.it/non-recidereforbice-quel-volto/.

41 La responsabile Giovanna Brambilla ha pubblicato, nel maggio del 2021, il libro Soggetti Smarriti che tocca i temi della necessità di dialogo tra musei e il pubblico, per un fondamentale confronto con la collettività e una nuova progettualità dedicata alle persone marginali e fragili. 
Bourdieu, P.; Darbel, A. (1969). L'Amour de l'art. Les musées d'art européens et leur public. Paris: Les Éditions de Minuit.

Cameron, D. (1968). «A Viewpoint: The Museum as a Communication System and Implications for Museum Education». Curator, 11(2), 33-40.

Cameron, D. (1971). «The Museum, a Temple or the Forum». Curator, 14, 11-24.

Cameron, D. (1995). «The Pilgrim and the Shrine: The Icon and the Oracle». Museum Management and Curatorship, 14(1), 47-55.

Campolmi, I. (2011). «'What is a Modern Art Museum?' Palma Bucarelli e la GNAM: il modello del MoMA in Italia». Cantatore, L.; Zagra, G., Palma Bucarelli a cento anni dalla nascita = Atti della giornata di studi (Roma, Biblioteca nazionale centrale, 25 novembre 2010). Roma. Biblioteca Nazionale Centrale, 51-69.

Cicchinè, M. (2020). «Webcolloquio nel lockdown: intervista a Paolo Crepet». Piraina, D.; Vanni, M. (a cura di), La nuova museologia: le opportunità nell'incertezza. Verso uno sviluppo sostenibile. Torino: Celid, 43-50.

Coleman, L.V. (1927). Manual for Small Museums. New York: G.P. Putnam's Sons.

Colombo, M.E. (2020). Musei e cultura digitale. Fra narrativa, pratiche e testimonianze. Milano: Editrice Bibliografica.

Cresti, C. (1976). «Dall'architettura museografica all'architettura museologica». Museologia, 4, 84-93.

Damioli, G. (2011). Analisi dell'esperienza museale e delle forme di apprendimento in un'istituzione tecnico-scientifica e della cultura materiale. Il caso del Museo dell'energia idroelettrica di Cedegolo-Musil [tesi di dottorato]. Bergamo: Università degli Studi di Bergamo.

De Carli, C. (2003). «Argan: L'arte di educare». Lorandi, M.; Pinelli, O. (a cura di), Rileggere Argan. L'uomo, lo storico dell'arte, il didatta, il politico $=$ Atti del convegno (Bergamo, 2002). Bergamo: Moretti \& Vitale, 94-110.

Della Pergola, P. (1980). «La didattica dei musei». Romanelli, P. (a cura di), Museo perché, Museo come. Saggi sul museo. Roma: De Luca, 87-8.

Deloche, B. (1985). Museologica. Paris; Lyon: Publication de l'Institut interdisciplinaire d'études Epistémologiques.

Dragoni, P. (2015). «'Accessible à tous': la rivista 'Mouseion' per la promozione del ruolo sociale dei musei negli anni '30 del Novecento". Il capitale culturale. Studies on the Value of Cultural Heritage, 11, 149-221. http://dx.doi. org/10.13138/2039-2362/1176.

Dragoni, P. (2016). «'La concezione moderna del museo' (1930). All'origine di un sistema di regole comuni per i musei». Il capitale culturale. Studies on the Value of Cultural Heritage, 14, 25-51. http://dx.doi.org/10.13138/2039$2362 / 1464$.

Ebani, F. (2021). «Così i musei pensano di riaprire e reinventarsi dopo la pandemia». Internazionale, 11 gennaio. https://www.internazionale.it/reportage/francesco-ebani/2021/01/11/musei-covid-19

Ferrio, S. (2020). «I musei del post-Covid investono in sicurezza e creatività». Smartbuildingitalia, 6, 28-9. https://www.smartbuildingitalia. it/wp-content/themes/smartbuilding2018/assets/images/ SmartBuildingItalia-N6.pdf.

Gamba, C. (2009). «Introduzione». Argan G.C., Promozione delle arti, critica delle forme, tutela delle opere. Scritti militanti e rari (1930-1942). A cura di C. Gamba. Milano: Marinotti, 5-35. 
Gaudibert, P. (1970). «ll museo d'arte moderna, animazione e contestazione». Ribaldi, C. (a cura di), Il nuovo museo. Origine e percorsi, vol. 1. Milano: II Saggiatore, 64-72.

Gray, P. (2015). Lasciateli giocare. Torino: Einaudi.

Gremigni, E. (2001). «Breve storia degli orientamenti teorici e legislativi intorno alla didattica museale in Italia». BTA - Bollettino Telematico dell'Arte, 268.

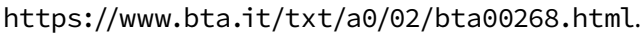

Hooper-Greenhill, E. (2006). «Studying Visitors». Macdonald, S. (ed.), A Companion to Museum Studies. Malden (MA); Oxford; Victoria: Blackwell, 362-76.

Kinard, J. (2005). «Intermediari tra il museo e la comunità». Ribaldi, C. (a cura di), Il nuovo museo. Origine e percorsi, vol. 1. Milano: Il Saggiatore, 64-72.

Lollobrigida, C. (2010). Introduzione alla museologia. Storia, strumenti e metodi per l'educatore museale. Firenze: Le Lettere.

Mandarano, N. (2019). Musei e media digitali. Roma: Carocci Editore.

Marrocco, M. (2011). «ll Museo negli scritti di Giulio Carlo Argan». teCLa. temi di Critica e Letteratura artistica, 3, 8-31. http://www1.unipa.it/tecla/contenuti/pdf/rivista3_montaggio/prove/numero3_marrocco.pdf.

Muséographie. Architecture et Aménagement Des Musées d'Art (1934) = Acte de la Conférence Internationale d'Études (Madrid, 1934). [Paris]: Société des Nations; Office international des musées; Institut international de coopération intellectuelle.

Pavis, Y. (1971). «Vers le musée du futur-entretien avec Pierre Gaudibert». Opus international, 28, 27-33.

Pinelli, A. (2012). «Giulio Carlo Argan, un intellettuale europeo». Gamba, C. (a cura di), Giulio Carlo Argan. Intellettuale e storico dell'arte = Atti dei convegni (Roma, Accademia Nazionale dei Lincei, 19 novembre 2009; Roma, Sapienza Università di Roma, 9-11 dicembre 2010). Milano: Electa, 29-38.

Piraina, D.; Vanni, M. (2020). La nuova museologia: le opportunità nell'incertez$z a$. Torino: Celid.

Primerano, D. (2020). «Creare comunità nel tempo sospeso della pandemia». Il capitale culturale. Studies on the Value of Cultural Heritage, 11, 213-29. https://riviste.unimc.it/index.php/cap-cult/article/ view/2530/1737.

«Recommandation concernant les moyens le plus efficaces de rendre les musées accessibles à tous». Organisation des Nations Unies pour l'Éducation la Science et la Culture (éd.), Actes de la Conférence Générale. Onzième session. Résolutions = Acte du Conférence (Paris, 1960). s.l.: UNESCO. https:// unesdoc.unesco.org/ark:/48223/pfo000114583_fre.page $=128$.

Remeir, W. (2020). «Canadian Museum for Human Rights Collecting Personal COVID-19 Stories». Global News, 30 March. https://globalnews.ca/ news/6750421/canadian-museum-for-human-rights-coronavirus-covid-19-stories/.

Ribaldi, C. (a cura di) (2005). Il nuovo museo. Origine e percorsi, vol. 1. Milano: Il Saggiatore.

Rigolo, P. (2009). «L'ARC di Pierre Gaudibert». Nuova Museologia, 20, 15-16.

Russoli, F. [1981] (2012). «ll museo come elemento attivo nella società». Il capitale culturale. Studies on the Value of Cultural Heritage, 4, 219-24. http:// dx.doi.org/10.13138/2039-2362/321.

Sasha Piccato, N. (2020). «ll ruolo del museo per le nuove generazioni. Educazione, cultura e utilizzo delle tecnologie come fattori di integrazione nel- 
la società post-confinamento. Il caso dei musei canadesi». Piraina, D.; Vanni, M. (a cura di), La nuova museologia: le opportunità nell'incertezza. Torino: Celid, 149-60.

Sassi Merien, B. (2007). Le musée à l'ère de l'Internet [thèse de doctorat]. Paris: Sorbonne Université.

Screven, C.G. (1969). «The Museum as a Responsive Learning Environment». Museum News, 47(10), 7-10.

Wittgens, F. (1956). «Concerti, radio, televisione, visite guidate». Atti del convegno di museologia organizzato in collaborazione con la Accademia Americana in Roma = Atti del convegno (Perugia, 18-20 marzo 1955). [Perugia]: Stabilimento tipografico Carlo Colombo, 57-62.

Won-Joo, S. (2020). «La Corea del Sud e i suoi musei nell'era COVID-19: strategie, buone pratiche e problematiche legate alla sostenibilità sociale ed economica». Piraina, D.; Vanni, M. (a cura di), La nuova museologia: le opportunità nell'incertezza. Torino: Celid, 77-90.

Zuliani, S. (2009). «'Vitrine de référence'. Alcune premesse e qualche ipotesi sul museo del XXI secolo». Chiodi, S. (a cura di), Le funzioni del museo. Arte, museo, pubblico nella contemporaneità = Atti del convegno internazionale (Roma, 3-4 aprile 2009). Firenze: Le Lettere, 151-81. 



\title{
Knowledgescape
}

Insights on Public Humanities

edited by Eugenio Burgio, Franz Fischer, Marco Sartor

\section{Heritage Thinking. Approaching Communities with Communication in the Venice Countryside}

Elisa Corrò

Università Ca’ Foscari Venezia, Italia

\begin{abstract}
Digital and Cultural Heritage studies reinforced the meaning to communicate and make creative use of information to express complex data. Moreover, the power of narratives and re-living memories lead to the creation of a series of emotional events. This paper focuses on a series of case-studies regarding the interplay between society and the landscapes around Venice (Italy), and the way cultural memory is encoded and interpreted. The communities' engagement is reinforced by the use of a citizen-science approach, which aims at facilitating the dialogue, sharing knowledge and involving citizens in academic research and dissemination of results.
\end{abstract}

Keywords Digital humanities. Environmental humanities. Citizen-science. Public engagement. Venice lagoon. Landscape archaeology. Water management. Cultural heritage management. Brain computer interface. Creative industries. Media art.

Summary 1 Introduction. - 2 Engagement Strategies. - 2.1 Immersive Technology. 2.2 Emotional Approach: Exploring the Influence of Culture on Human Consciousness.

- 2.3 Visual Narrative. - 2.4 Citizen-Science Approach with Open Data. - 3 Discussion.

-4 Conclusion. 
Remember to look up at the stars and not down at your feet. Try to make sense of what you see and wonder about what makes the universe exist.

Be curious.

And however difficult life may seem, there is always something you can do and succeed at.

It matters that you don't just give up.

(Stephen Hawking)

\section{Introduction}

In recent decades, the landscape of Digital and Public Humanities (Terras et al. 2013; Warwick et al. 2012) highlights the dialogue across disciplinary boundaries and offers promising prospects for future research as an essential resource for knowledge preservation, exchange and dissemination (Cooper 2014; Ellison 2013; Moshenska 2017; Nussbaum 2010).

From this perspective, this article analyses, with a series of examples, the implication of digital technologies in the preservation, management and interpretation of cultural and natural heritage as a way to transform institutional cultures, methods, and relationships with audiences (Cameron, Kenderdine 2007; Ciotti 2016). Indeed, interdisciplinary projects in Digital and Cultural Heritage connects and supports multiple fields including maker culture, ${ }^{1}$ co-created inclusive narratives and construction of cultural identity through a spatial-linguistic transformation of knowledge. ${ }^{2}$ Digital technologies are in fact used by researchers, academics and professionals working on heritage to generate innovative ideas, to express complex information and make creative use of information and data, making knowledge more accessible and engaging for different kinds of audiences (Bartscherer, Coover 2011; Hayles 2012; McGann 2005).

Within this context, it is important to consider the Environmental Humanities, the new academic field emerged since last decade, interested in environmental issues and actual global challenges (Emmett, Nye 2017). Therefore, the relationship that people have with

1 For details, see the IGNITE digital roundtables on Design Thinking \& Maker Culture: Sticky Learning for the 21st Century held online through April 2020: https://www. youtube.com/watch?v=Iys2wAZvpQg\&list=PL77mHK9JuenNSyeZtTRweXNU71nh14gD9.

2 For more, see the open lesson "Maker Culture: When Archaeology Meets Creativity", delivered in English by Elisa Corrò (Venice Centre for Digital and Public Humanities-VeDPH) on July 6, 2020, held online within the VeDPH Virtual Summer Camp in Digital and Public Humanities 2020 (strand 4: Digital Archaeology and Its Public). Organisers: Department of Humanities of Ca' Foscari University; Venice Centre for Digital and Public Humanities; Research Institute for Digital and Cultural Heritage. Recording available online: https://www.youtube.com/watch?v=p2MKNhOUZXw. 
their own cultural and natural heritage appears also more relevant, as a way to identify themselves with the environment, with their values and their traditions. In this sense, each natural, historical and archaeological element represents the heritage that people have inherited from the past and that want to transmit to future generations.

In particular, this article presents several examples of community engagement, highlighting the importance of understanding the approach to communicate with people that live in environments characterised by sustainability challenges, such as lagoons and rivers, or rather by a strong relationship and management between natural and anthropic changes. The challenge, therefore, lies in promoting the engagement of society in participatory ways with the principles of heritage education, not only increasing engagement with place and memory assets, but ways to create dialogue, cohesion, identity and a sustainable development.

From this point of view, the geographical setting of the article is the Venice Lagoon and its hinterland (Italy) as a territory constantly modified over the centuries by both artificial and natural events (Corrò et al. 2021; Moine et al 2017). For instance, the existing border between dry land and the lagoon is now completely artificial and it was built to divide the lagoonal environment from fresh water (Corrò et al. 2015). Moreover, in the Middle Ages and in the Modern Era the main urge was to prevent the fluvial depositions, for Venice as well for the countryside: the city government turned its attention on this area only to fix the hydrologic balance of the lagoon, meanwhile the inhabitants continued to reclaim and to modify land and rivers to maximise its exploitation (Corrò et al. 2018).

From this perspective, the article is landscape-oriented with special attention to environmental changes due to water management activities that began in the past (detected with archaeological and historical studies) and that has an impact on the present communities and places (Corrò et al. 2019). In this sense, it attempts to document how local communities are related - culturally and emotionally - to water management. The subjects concerning the interplay between man and the environment, the key role of the hydrography in constraining land use dynamics, and the relation with culture and society reinforce the meaning of identity as defined in the Code of the Cultural and Landscape Heritage, in which the term 'landscape' is defined as "an integral part of the territory whose characteristics are derived from nature, the history of humanity or from their reciprocal inter-relationships". ${ }^{3}$

3 Legislative decree no. 42/2004, article 131, available at https://whc.unesco.org/ document/155711. 

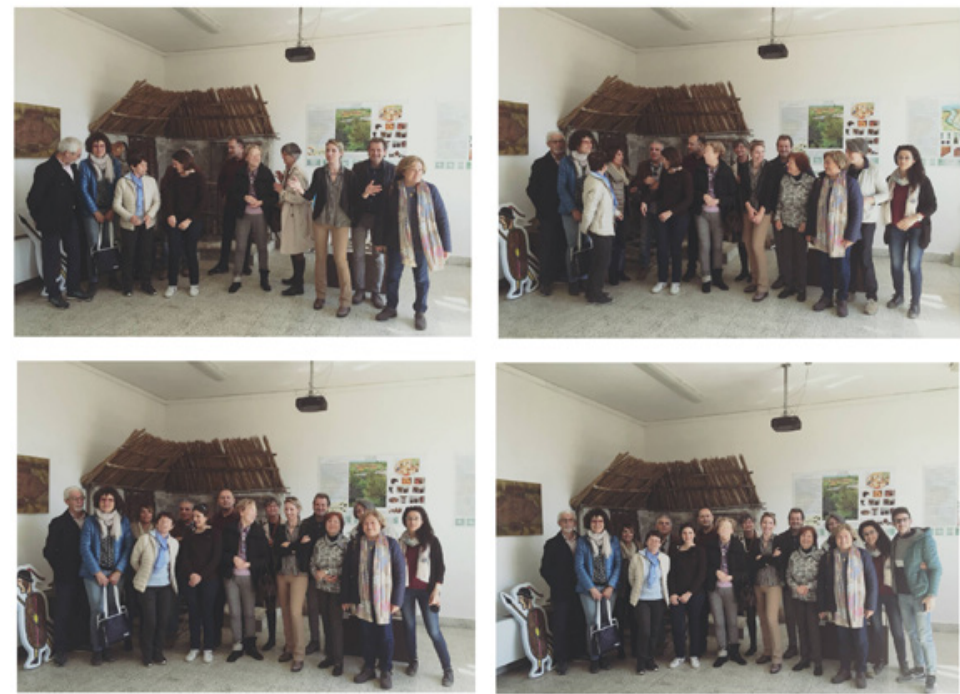

Figure 1 Visit (in 2019) to the Archaeological Group Mino Meduaco (Venice, Italy) by the Camponogara Open University class of the course "Venice, from the Lagoon to the Brenta River: Environment, Geology and History", held by Elisa Corrò

\section{Engagement Strategies}

The role of new technologies in the management of cultural heritage and the promising research in interdisciplinary sectors, such as design thinking, digital storytelling and creative narratives, represent the most effective tools to communicate, visualise and generate innovative ideas and make creative use of information, data and media to express complex information. Moreover, the use of a citizen-science approach, with the interplay between cultural society and local requirements, help to facilitate the dialogue, to share co-produced knowledge, to involve citizens in academic research and in the dissemination of the results (Heinisch 2020). From this perspective, to make the meaning-making actions in the cultural heritage activities more inclusive, participation and interaction processes are mainly based on the engagement of a group of people in a common activity represented by a common interest, named 'affinity place', letting them find their space and their identity (Gee 2004; 2005) [fig. 1].

The following examples are part of public engagement projects and they suggest different approaches of heritage thinking applied on several academic works in the Venetian area, to improve citizen participations and the promotion of cultural diversity. They are based on synergic multidisciplinary approaches, involving public, private, 
and institutional agents: geologists, archaeologists, geographers, but also digital storyteller, media artists, creative directors, architects, neuroscientists and engineers.

\subsection{Immersive Technology}

The concept of multisensorial experience through the use of immersive technologies is generally based on the creation of a direct engagement between the viewer and the high technological content. An immersive experience could generate a relaxed environment that raises awareness, establishing a universal way of communication. In recent years the use of immersive rooms has become useful in the private companies as well as in the public institutions. For instance, they are frequently used for innovative marketing, as a new idea of showroom for the business, and are very well distributed in every industrial sector: from digital technology to manufacturing processes and equipment, from automotive and fashion industry to industrial design. In the public institutions, especially those related to cultural heritage, immersive rooms represent the ideal way to recreate ancient environments in a very emotional way. Moreover, in archaeological museums or exhibitions, they often contribute to making knowledge even more accessible for different kinds of audiences. For instance, in the multi-sensorial experience of the ancient roman Temple of Mithras recreated at Mithraeum Bloomberg SPACE in London, where visitors enter this underground temple museum and experience seeing the walls of the ancient Temple into view, while an audio replicates bells and rituals. ${ }^{4}$ The Fram Museum in Oslo (Norway) is another suggestive experience. In the room there are more then $10 \mathrm{~K}$ projectors that create a glacial backdrop so that visitors feel completely surrounded when on the deck of the ship. ${ }^{5}$ Immersive experience could be not only limited to a single room but also represented by an entire visit. For instance, the Magister Canova exhibition (Venice, Italy) was a complete immersive travel through multimedia art. ${ }^{6}$ In the field of public art there is an innovative project that uses a parametric data sculpture approach (with machine intelligence) to create immersive installation aesthetically rendered by visual performance. ${ }^{7}$ All of these special environments can transform a visit into an interactive experience very useful also for education, and able to influence, develop and create innovative teaching methods.

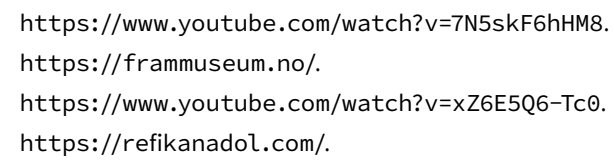


The positive impact of an immersive space can be seen throughout the school, such as improving behaviour and wellbeing, and creating greater engagement. ${ }^{8}$

One incisive method to create participation and awareness is the use of immersive technologies to enable the creation of experiences that can bring the past to life. In this sense, the concept of immersive technology related to the landscape acquires different perspectives. Sights, sounds and even smells can be recreated to help people understand the world (and its history) as it was or might be, following the idea of a memory-scape, simply studying how people respond to immersive experiences with personal histories relating to historical events (Rogage et al. 2021; Swords et al. 2020). This is the reason why researchers are interested in how people consider their personal history, for example uploading family photos on the web connected to particular events (Severo 2009; Jones et al. 2018). In fact, in recent years, the need to strengthen cultural identity belonging to the landscape and the related environment has emerged in several interdisciplinary university projects. This has led to the creation of a strong connection with the landscape adding a giving value to the knowledge and awareness of what surrounds us. For instance, the concept of a dynamic landscape is a current research theme by Harvard University Graduate School of Design. In recent years, Harvard University actually worked on several projects related to this topic. For instance, Pulsus, an experimental installation that collects real-time data from the cityscape and reinterprets the dynamic information into interactive soundscapes to create a deep interaction with citizens. ${ }^{9}$

The inner sense of the interrelation between man and the environment and the perception that people have of reality is also considered a new kind of conceptual and experiential working space (Malpas 2011; McRobert 2007). There are projects focused on decentralising human position in the world, on de-habituating perception and resensitizing people to their being in the world. Similarly, Ephemère is an immersive installation structured into three levels: landscape, earth, and interior body. ${ }^{10}$ The landscape changes continually, passing through a sort of cycles, so the participant may pass constant-

8 See for instance the Atelier des Lumières: https://www.atelier-lumieres.com/ en/home.

9 The project, realised by Harvard University Graduate School of Design in collaboration with Cambridge-based INVIVIA and the GSD's Responsive Environments and Artifacts Lab (REAL), is directed by the associate professor of Practice in Architectural Technology, Allen Sayegh. For more: https://www.gsd.harvard.edu/2017/09/responsive-environments-and-artifacts-labs-pulsus-featured-in-domus/; https://research.gsd.harvard.edu/real/portfolio/pulsus/.

10 http://www.immersence.com/. 
ly between changes, immersed in transformation, as well as giving priority to the environment as a place that can potentially facilitate a dissolution of conventional boundaries between perceiver and perceived (Davies 2003).

Regarding cultural heritage, some scientists want to go one step further by taking into account the dimension of human environmental studies and aim to highlight the disregarded thematic that connect humanities, natural sciences and informatics. In this case, the Maurizio Forte's team, Dig@Lab at Duke University (North Carolina), is a team specialised in archaeology and new digital technologies that works in this direction, offering new projects regarding the aspects of sound-scapes or smells-capes in the 'digital cities' (Forte, Murteira 2020). Is it now possible to communicate to the present community these stories and the awareness of those places in which people live today? How could the interactions between man and environment be a way to respond to today's changes in the relationship of humans with the environment? Is it possible to increase these matters in educational programmes regarding the conservation of heritage?

\subsubsection{The Immersive Experience for an Archaeological Site}

The Living History on the Edge of the Lagoon was a project realised during the years 2018-19 by Ca' Foscari University of Venice.$^{11}$ Funded by the Veneto Region, the project involved several private and public institutions ${ }^{12}$ for the development of new solutions for the cultural heritage of a territory that was completely transformed during the ages, due to water management. The project was focused on the use of immersive technology to promote the southern Lagoon of Venice and its mainland. This geographic context is indeed characterised today by a road network perfectly integrated with small rivers, canals and the famous Brenta River (the 'Riviera del Brenta' is, indeed, an amazing tourist attraction), and it includes the archaeological site of Sant'Ilario, an ancient monastery, one of the most ancient religious institutions of Early Medieval Venice, known as the site of many ducal burials during the Early Middle Ages (Corrò et al.

11 POR-FSE 2014-2020-CUP: H76C18000230005. Project title: Living History on the Edge of the Lagoon: The Variation of the Coast Line Over the Centuries with Immersive Technologies for the Promotion of Cultural Heritage (project code: 2120-3-11-2018). Scientific director: Sauro Gelichi, Professor of Medieval Archaeology at Department of Humanities of Ca' Foscari University of Venice; fellow: Elisa Corrò, Venice Centre for Digital and Public Humanities.

12 Project partners: visiting professor Sebastiàn F. Ramallo Asensio, The 'Abdus Salam' International Centre for Theoretical Physichs, Multidisciplinary Laboratory (ICTP Mlab), DrawLight srl, Ca' Foscari Challenge School, Oikos Coccato Architettura. 
2015; 2018; 2019). Within this fluvial context, the study of the territory reveals extreme anthropogenic landscape transformations over the centuries in order to maintain a strategic position in the river network. Moreover, a series of strong processes of intervention starting in the 20th century has disrupted the site for the construction of a small village still existing today. ${ }^{13}$ Oral traditions are helping to explain when, how and where it all happened.

From this point of view, the current landscape represents the result on which these changes can be read, expressed and perceived by the inhabitants themselves. In this sense, rethinking on these relationships can only contribute to a more conscious use of the territory. Therefore, the activities planned in the project aim to fill the gap of awareness expressed by the present society. ${ }^{14}$ Digital technologies have revealed to be the most effective tool to communicate and translate a case study as a model that can be used from an economic and cultural sector. In particular, the project focused on immersive technologies, the ideal tools to identify and become literally protagonists of the situation once entered in the room. The collaboration of this project with the University and local companies led to combine transferable skills, such as creativity, critical thinking, self-learning, developing a collaborative approach towards a sustainable heritage.

\subsubsection{A Heritage for Mankind}

The final event of the Living History project was created to foster contamination between local companies and academic research, promoting economic and social cohesion. A Heritage for Mankind ${ }^{15}$ involved professors and businessmen, from cultural foundation directors to

13 During the '70s of the 20th century the continue and complete disruption of churches and structures has served to the construction of a small village, known as 'Villaggio of Ca' Emiliani' located in the present Marghera Municipality (Corrò et al. 2021).

14 See also the virtual presentation of Elisa Corrò: "Becoming us. How Invisible Heritage can be the Story of our Awareness" at the Eighteenth International Conference on New Direction in the Humanities. Transcultural Humanities in a Global World (Ca' Foscari University of Venice, 1-3 July 2020). For more information: https://cgscholar. com/community/community_profiles/new-directions-in-the-humanities/community_updates/122164.

15 Event title: A Heritage for Mankind. Research Data Translated into an Immersive Key for the Use of Heritage. From an Archaeological Excavation in the Mainland of Venice, to a Palladian Villa, to the Birth of the Riviera Del Brenta, organised by Ca' Foscari Challenge School in collaboration with DrawLight srl on September 2019, 11th at DrawLight srl. Speakers: Alberto Gentilin (Key Account DrawLight srl), Andrea Gion (Ambassador and Academy Trainer), Elisa Corrò (fellow at Ca' Foscari University of Venice). Special guests: Mick Odelli (Founder\&Innovation at DrawLight srl), Micol Lorenzato (Marketing\&Communication strategist at DrawLight srl), Sebastiàn F. Ramallo Asensio (Professor of classical archaeology at University of Murcia, Spain, expert in herit- 
bankers, sales and marketing directors. It was an opportunity to talk about innovation investment. The main purpose for the meeting was to make people protagonists of a project for promoting cultural heritage. The topics discussed were connected to how to: leave a legacy, narrate the past, make the landscape archaeology a current topic within the contemporary information processes, create a community of people capable of living through a healthy awareness of cultural value. As a result, the immersive technology appears to be the ideal tool to awaken individual creativity as an expression of the collective imagination. In this way it was possible to narrate a story with three mocks up that derives from the translation of the research information (data) into values, to be projected in an immersive room, creating an environment where once you enter you become the main character, experiencing real sensations. The first mock up regards the variation of the coast line over the centuries. It was based on satellite imagery, on a series of radiocarbon dates from geoarchaeological researches and on the studies of ancient cartography. It was created to describe in an artistic way the differences between the present condition and the past [fig. 2a].

The second digital content aimed to define a change of mentality in understanding the landscape: from a land with water issues during Middle Ages to a suitable spot for Renaissance Villas. The concept was instilled with a series of positive stimuli related to sensations, sounds and impressive visualisations to describe the extreme event [fig. $\mathbf{2 b}$ ]. The third prototype imparted the changing of water level figures during the ages in an abstract form, in contrast with the materiality and the physical concreteness of the ancient monastery mosaics [fig. $2 \mathrm{c}$ ].

From this point of view, using historical, archaeological and geological data in a new environment contributes to making the pastpresent connection more accessible, bridging the gap between the academic world and the local community, and finally reinforcing the perception of a heritage that is intangible. This project has reinforced the linguistic knowledge conversion, simplifying technical language to transform the heritage into an experience that eases knowledge forwarding.

age, landscape and interactive museum exhibition). For a presentation of the event see https://www.youtube.com/watch?v=H1UhlMTOj4c. 
Elisa Corrò

Heritage Thinking. Approaching Communities with Communication in the Venice Countryside
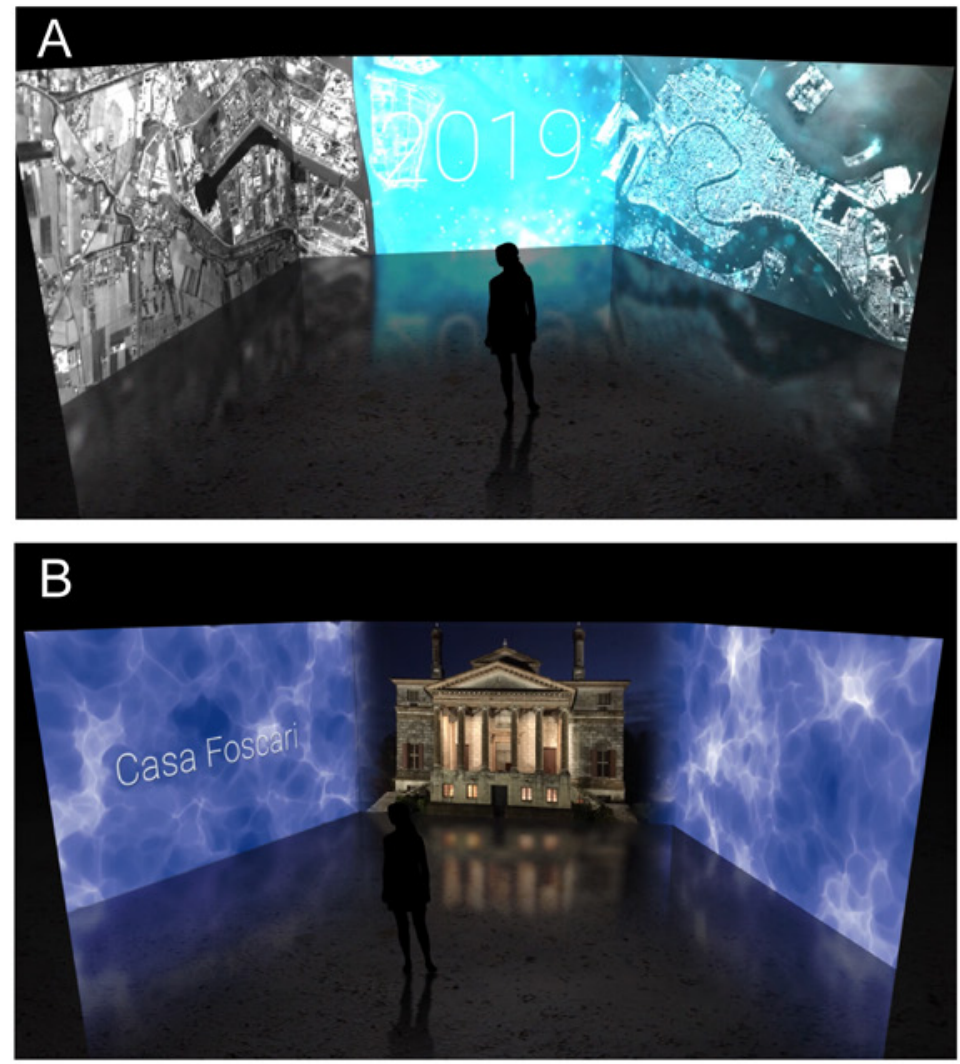

\section{C}

Brenta River date: 1100 AC in collaboration with DrawLight srl (www.drawlight.net): a) water changes; b) Villa Foscari-Brenta River c) Sant'llario archaeological site 


\subsection{Emotional Approach: Exploring the Influence of Culture on Human Consciousness}

How can we create a deeper relationship between the general public and the cultural landscape? In the last decades, the Brain Computer Interface (BCI) technology (Nijholt 2019) has been used to explore the state of mind in several disciplines. In particular, the brainwaves are studied to analyse mindset recognition, creating electroencephalogram (EEG) patterns in response to visual images (Bobrov et al. 2011) and identifying emotions in children with special educational needs (Lekova et al. 2018). EEG are also analysed to detect specific state of minds, as mental alertness (Sawicki et al. 2016), cognitive distraction (Sena et al. 2016) and learning ability in normal and virtual reality conditions. Moreover, in cultural sectors they are used to study the real involvement, for instance in archaeological site, and to define the embodiment in artistic expressions, such as dance and somatic practice (gestural dialogue) (Hieda 2017), theatre (Oskooyee, Banerjee, Gupta unpublished), music and performance (Paradiso 1999).

From this perspective, it is particularly relevant the approach used by different scientists to explore whether there is a place in human consciousness in which it is possible to recognise the levels of emotional intensity. First of all, in 2016 Ellen Pearlman ${ }^{16}$ (2017) created the first full opera in which a performer wore a wireless brainwave headset. It was during that emotionally powerful and immersive experience that it was possible to map emotional categories and create patterns to different mental status. Regarding the use of EEG, 'the Brain Opera' directed by Joseph Paradiso ${ }^{17}$ was another tracking general public's feelings through an interactive installation of musical instruments (Paradiso 1999). Moreover, thanks to Harvard University Graduate School of Design research it is possible to understand the relationship between perceived emotions from the related environment and the actual state of mind based on stimuli triggered by the environment. In particular, with Chroma project it is possible to measure people's emotional state in a city or place through feelings, colours and emotions. ${ }^{18}$

Those are all experimentations, especially used by designers and architects. But is the emotional approach really useful for a public use in cultural heritage? It is clear that the power of narratives, re-

16 School of Creative Media, Hong Kong City University, director of the Volumetric Society of New York and president of Art-A-Hack ${ }^{\mathrm{TM}}$ based in Brooklyn, New York.

17 MIT Media Laboratory of Massachusetts Institute of Technology.

18 The project Chroma: Colors and Emotions in Cities. Genome of the Built Environment: Measuring the Unseen was realised by Harvard University Graduate School of Design. For more information see https://research.gsd.harvard.edu/real/portfolio/chroma/. 
living memories and visual experiences leads to the creation of a series of emotional events. This concept is used by neuroscientists as the "constructing emotions approach" (Feldman Barret 2011; 2017). In fact, they have recently demonstrated that emotions are a kind of dynamic state of mind directly connected with the environmental and cultural context. Without a cultural context, only a partial description of what is happening is available, the whole history is not known, the complete picture is missing. It is in the completeness of the picture, in the totality of the story, that emotions are truly captured. From a neuroscience and psychological point of view, this approach is directly connected with the place in which a person lives and to the natural and cultural evolutions of that territory. In this sense, today's personal life is the result of environmental crafting.

\subsubsection{An EEG Headset for Cultural Heritage}

EEG systems that use advanced signal processing algorithms could be a valid instrument for scientists who want to go one step further by taking into account a deep dimension of knowledge and aim to highlight the disregarded thematic that connect humanities, environments, neurosciences and human behaviour. The headset is indeed able to measure data through brain signals with a monitoring method that can record the electrical activity of the brain (Nicolas-Alonso, Gomez-Gil 2012). Through the measure of strengths between different brain regions it is able to classify the emotional state. With this kind of headset, a person's real-time attitude can be used in an immersive experience or in a specific place to create a stronger engagement. For instance, during the event Living History: $8 \mathrm{kms}$ Over the Centuries, ${ }^{19}$ a walk-through Venice's countryside history, the potential of this kind of technology was evidenced to general public [fig. 3].

The main aim of this experience was to bring attention to the intangible mental connection that people have with the cultural landscape and make it tangible with these devices, through the change of mental state based on the environmental context. In particular, the walk passes through a natural landscape nearby the historical river, a fascinating villa on a reclaimed area, and an archaeological site completely invisible due to natural and artificial transformations. In this sense, the walk was characterised by a travel through time and by a dialogue across the boundaries of human behaviour and know-

19 The event was organised on 9 June 2019 by Elisa Corrò, Department of Humanities of Ca' Foscari University of Venice and Ca' Foscari Challenge School, in collaboration with Nordic Walking Association within the project Living History on the Edge of the Lagoon (POR-FSE 2014-20). 


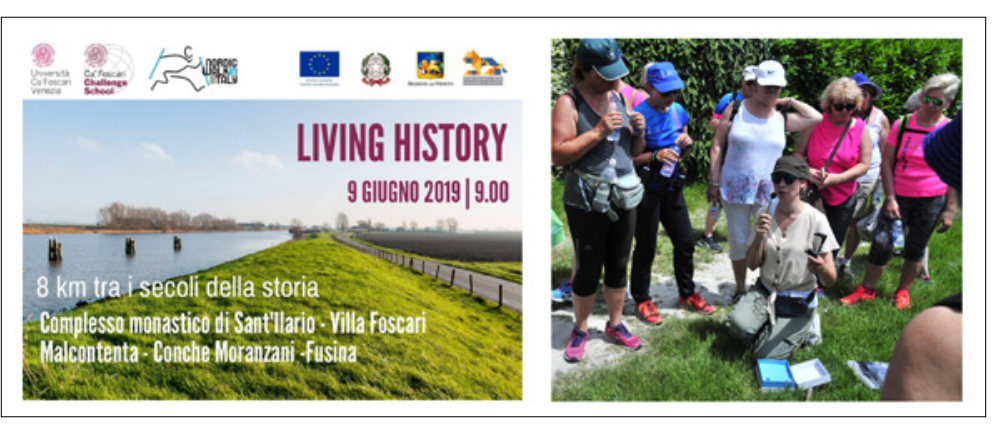

Figure 3 Details of the event: $8 \mathrm{kms}$ of Living History with the explanation of the potential of a brain sensor (in this case Muse headband: https://choosemuse.com)

ledge preservation. Moreover, the adoption of a more emotional storytelling experience contributed to giving new ways to understand, interpret and spread information, and establishing (with the headset) a universal way of communication. This could be a valid solution to produce innovative programs that engage communities, individuals and professionals with culture.

\subsection{Visual Narrative}

Storytelling is the best vehicle to create interest, empathise and stimulate imagination (Johnsson 2006). In recent years it has been used to create inspiring narrations in several sectors, both academic and professional, as well as from the specialists in marketing sectors. As far as the marketing professionals are concerned, this is obviously a very important subject. It is indeed a much debated topic even in the Content Marketing World (CMW), one of the largest content marketing events organised every year by the Content Marketing Institute. ${ }^{20}$ In the 2018 edition of CMW, Joe Lazauskas, head of content at Contently, ${ }^{21}$ highlighted that all people as human beings, are, in a way, programmed for stories (Lazauskas, Snow 2018). Moreover, he also explained how the neural activity of a brain can gradually intensify during a narration, underling in this way the strong connection between the consciousness and the mind. ${ }^{22}$ According to other au-

20 https://contentmarketinginstitute.com/, https://www.contentmarketingworld.com/.

21 Contently is a company that creates storytelling for several brands. For more information see https://contently.com/.

22 https://www.youtube.com/watch?v=RAPdMVJ2MDc. 
thors, since the beginning, knowledge was transmitted through storytelling (Sandelowski 1994). From this perspective, (digital) narrations are participative stories. Thinking of ancient Greek orality, for instance, the narrator did not tell the story alone, but was helped by the participants, with voices, songs and more. In other words, it was the power of oral tradition. In this sense, Eric Havelock has interpreted classical poetry, from Homer to Plato, focusing on the communication changes, especially in the passage from oral to written traditions due to political issues at the end of the 5th century AD. He specified how poetry transmitted orally had been the vehicle for the dissemination of all scientific, legal, historical, religious and philosophical knowledge (Havelock 2019). The engagement of human behaviour in compelling narratives has been also recently studied by neuroscientists that point out a positive increasing in neural brain activity in the listening processes of a story (Zak 2015). In this way, people are more engaged in cooperative behaviours, attitudes and beliefs. In this sense, according to Eric Goodstadt, president of Manifest, and Sacha Reeb, chief creative officer at the Content Marketing Agency, ${ }^{23}$ an emotional visual media experience could improve the process of narration even more. Visual storytelling is indeed able to involve the use of graphics, images and videos to engage with viewers through the emotions, communicating more directly and transmitting the knowledge in an innovative way.

On the other hand, the approaches to storytelling for cultural and educational contexts are also concerned with the importance of an entertainment experience. The significance of narrative structure has to be combined with people's levels of interest, empathy and imagination (Schell 2005). In this sense, in storytelling is relevant to focus on curiosity, tension and to the creation of stories to be emotionally resonant to hold audience's attention. Therefore, the adoption of a more emotive storytelling experience is considered by many authors a way to engage with cultures a wider audience, as the prototype storytelling experience applied at the Ancient Agora of Athens (Roussou et al. 2017). For instance, visual historical drama-based narrative (Tolja 2013) or a comic narration have the potential of encouraging interactions and facilitating a deep knowledge transfer during, for instance, a visit experience. In fact, in the Emotiv, an EU-funded heritage project, they use emotional storytelling to dramatically change the experience on heritage sites. ${ }^{24}$ From this perspective, the application of digital media tools to engage people with storytelling represents the best solution to communicate with different demograph-

23 See their intervention, "\#CMWorld 2019-Visual Storytelling at its Best-Eric Goodstadt \& Sacha Reeb”, in CMW 2019: https://www.youtube.com/watch?v=j83sKBN8pLk\&t=349s.

24 https://emotiveproject.eu/. 


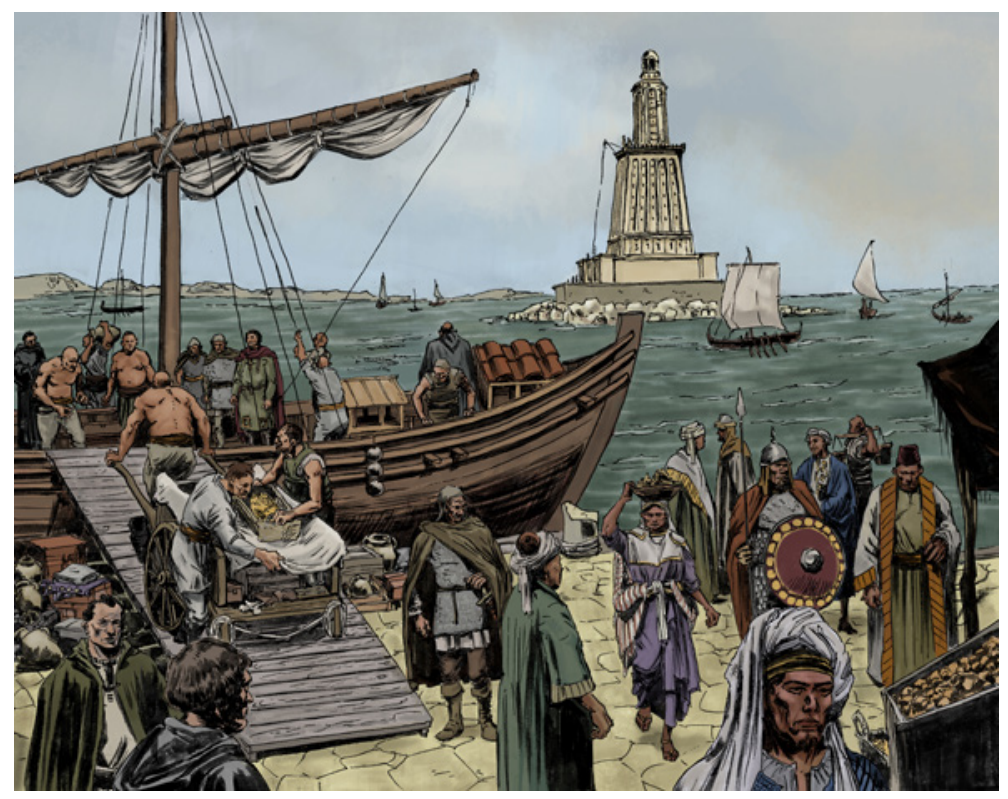

Figure 4 One of the strips realised for Before Marco Polo. The Origin of Venice by Francesca Zamborlini (cartoonist)

ics (D'Eredità et al. 2016). In this complexity, storytelling represents a significant source to tell a story, to explain historical events and to reflect on significant moments in our present.

\subsubsection{Before Marco Polo. The Origin of Venice}

An ongoing project of digital storytelling is the comic-based digital animation of the origin of the city of Venice [fig. 4]. Before Marco Polo. The Origin of Venice is indeed a project created by Ca' Foscari University of Venice ${ }^{25}$ for the exhibition Venice and Suzhou. Water Cities along the Silk Roads. ${ }^{26}$

The 8-minute story is set in a growing Venice from its origin, and reflects its urban landscape and the historical events during the ear-

25 Principal investigator: Sauro Gelichi in cooperation with Stefano Gasparri, Elisa Corrò (digital storyteller), Carlo Beltrame, Claudio Negrelli and Francesca Zamborlini (cartoonist), in partnership with Ca' Foscari University of Venice (Department of Humanities and Venice Centre for Digital and Public Humanities), Centro Studi Archeologia Venezia (CeSAV) and Fondazione Ca' Foscari.

26 At the moment the project is suspended due to the current pandemic situation. 
ly Middle Ages. The animation is based on comic strips that represents some dramatic episodes of the life of Duke Justinian Partecipazio and the usurper Caroso, combing tense moments, such as the theft of St. Mark's relic, with dark scenes related to the clashes with the Narentan pirates. With this animation, starting from drawings by a cartoonist, it could be possible to bring back the past (reconstructed by written sources) and help to explain it: under a Venice of brick and stone lies another city.

\subsubsection{Villa dei Leoni: Historical Heritage}

During COVID-19 times, collaborative projects are very important to preserve the dissemination of the cultural heritage. With Villa dei Leoni: Historical Heritage ${ }^{27}$ the Mayor of the District of Mira (Venice, Italy), in collaboration with Ca' Foscari University of Venice, ${ }^{28}$ wanted to highlight the cultural heritage, identifying the elements of the landscape that have been at the centre of many studies, also linked to the enhancement of places, in relation to their development.

\subsubsection{Venice River Collection}

A new challenge in the cooperative learning is the creation of a blogsite assigned to a specific territory. The improvement of the quality (in terms of more liveable) of these landscapes around Venice today recalls another key word - resilience - that is the need to 'equip' the city to overcome extreme events and the continuous stresses connected with climate change. From this point of view, in this context, the 'everyday landscapes' are also the most vulnerable ones, on which more attention needs to be paid. In the works of adaptation to climate change we are creating new 'everyday landscapes', working on those that are not only degraded but also more vulnerable. But with what results? With what involvement of the local populations? Can adaptation projects improve the quality of the cultural landscape? The Venice River Collection blogsite ${ }^{29}$ is public-oriented, with the story of a specific site and its travel through time until the present, and with a beautiful gallery of images via Instagram..$^{30}$ Each story is about a particular topic, from preservation to conservation,

27 The outcome of the project will be available soon.

28 Scholars involved: Sauro Gelichi (Department of Humanities), Elisa Corrò and Franz Fischer (Venice Centre for Digital and Public Humanities).

29 https://discover-venice.github.io/VeniceRiverCollection/.

30 See https://www.instagram.com/riverofvenicecollection/. 
and is guided by the slogan: "remember to preserve memories, connect and collaborate".

\subsection{Citizen-Science Approach with Open Data}

The landscape reflects multiple aspects of society, interpreted as the first producer of the landscape. There are elements that play a basic role both in the territorial governance process and in the community's safeguarding and awareness, such as the influences of anthropic activities on the feature of the landscape. However, it seems that people are increasingly struggling to recognise its importance and preservation, overwhelmed by the 'green' and 'plastic free' trends.

One of the attempts to improve the involvement of people is to use open data to describe a territory, searching information, together with citizens, among the wide range of data that are available online: from Google Maps to National Statistical Demographic Institute. In this way, it is possible to create not only a description but also, through the use of digital and media technologies, a data visualisation-story of the landscape in such a creative way.

\subsubsection{Archeohistory}

In summer 2020, Archeohistory, a public engagement project for young students that alternate school and work, was started. ${ }^{31}$ During this project was also tested a simulation regarding the aspects of communication with digital technologies through open data. ${ }^{32}$ The objective of this test was to create a narration and a collection of data to be processed in data visualisation open-source programmes available online. The second part of the test aimed to compare the present with the past, through the materiality of old pictures, going to

31 Project dedicated to the relationship between technology and archaeology of the Institute "Martino Martini" of Mezzolombardo (Trento, Italy) that involved several professors and researchers of different disciplines of Ca' Foscari University of Venice (Department of Humanities).

32 For the aspects regarding the innovative communication in archaeology with digital technologies: Water Matters. Digital Solutions and Communication Strategies for a Better Understanding of Past Extreme Events. Seminar delivered in English by Elisa Corrò (Venice Centre for Digital and Public Humanities) on April 22, 2020, held online within the VeDPH Seminar in Digital and Public Humanities 2019-20 series. Organisers: Department of Humanities; Venice Centre for Digital and Public Humanities; Research Institute for Digital and Cultural Heritage (Research for Global Challenges); International Center for Humanities and Social Change at Ca' Foscari University of Venice. Recording available online: https://www.youtube.com/watch?v=bdMJPiKIGXo\&l ist=PLzkDEscu2r2roGC_1Cbm1CZ_RcJvMYA70\&index $=7$. 


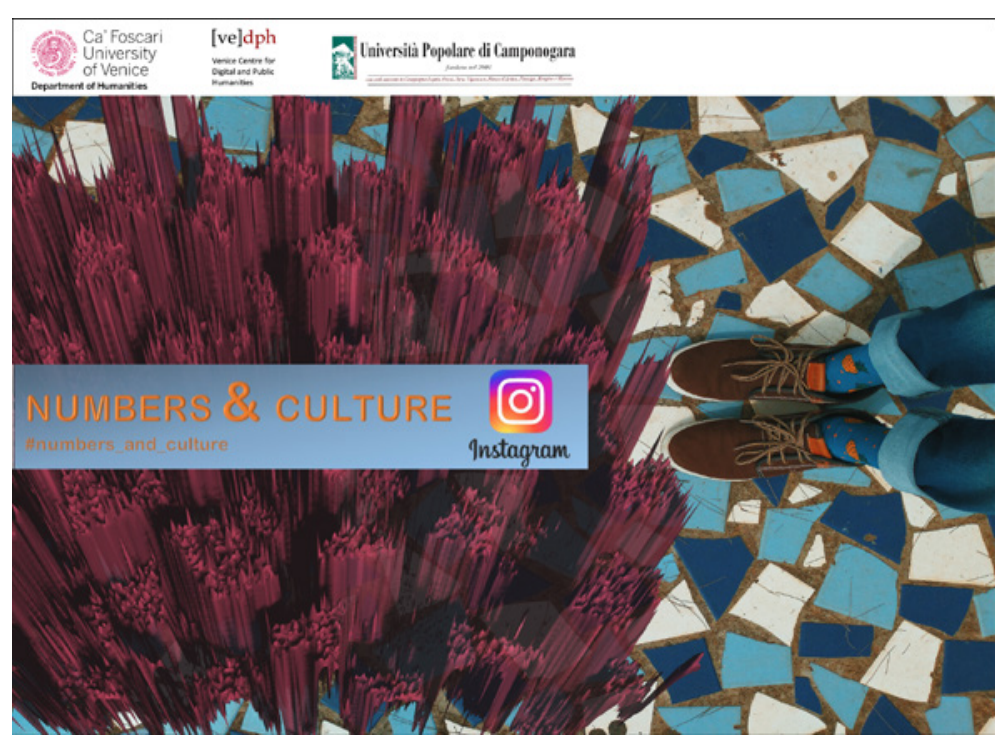

Figure 5 Presentation of the project Numbers\&Culture

libraries etc., but the COVID-19 emergency has forced to replan each single phase of the starting project. However, this test was very useful for researchers of multiple disciplines to understand how much people are related to the land in which they live, the perception they have and how well they know it.

\subsubsection{Numbers\&Culture}

The currently underway project aims to promote cultural heritage fostering the contamination between academic world and the community, especially during a period of pandemic situation. Numbers\&Culture involves a school belonging to the Venice countryside and several partners. ${ }^{33}$ The challenge focuses on an interdisciplinary research that includes: an open data search on the web as a

33 Scientific director: Sauro Gelichi, Professor of Medieval Archaeology at Ca' Foscari University of Venice; fellow: Elisa Corrò, Venice Centre for Digital and Public Humanities. The project is organised by the Department of Humanities and the Venice Centre for Digital and Public Humanities of Ca' Foscari University of Venice, in collaboration with the Institute A. Gramsci and the Open University of Camponogara (Venice, Italy) and ArcheoScuola (www.archeoscuola.it). For more information see https://www.unive.it/pag/14024/?tx_news_pi1\%5Bnews\%5D=10203\&cHash=1344bb6b8 ๑e64812a14f4d@1e92c63c8. 
way to describe with numbers the features of the present landscape; a collection of historical memories; a past-present comparison of the landscape changes by uploading pictures on Instagram through the hashtag of the project. ${ }^{34}$ Thanks to a team of researchers, the class analyses their research data in real time, with a series of data visualisation processes. The collection of information will be used to map and to increase the value of cultural assets. The final result, a documentary, was presented in the final event [fig. 5]. ${ }^{35}$

In this sense, the project is based on the need to give a greater awareness of cultural heritage, strengthening the sense of belonging to a territory and directly involving the community that lives there in an interdisciplinary experience. The characteristics of the target - students at a secondary school - aim to strengthen the preadolescent cognitive potential connected to the academic opportunities in the field of Digital Humanities, with unconventional strategies for the humanistic world, and engage a wider audience, indirectly involving the family in the activities of the students.

\section{Discussion}

The general overview presented in this article take into account different key points regarding heritage sector. Firstly, this paper tries to reflect on which (hi)story to tell in modern society, especially in this period of pandemic emergency. What is the meaning of the past in the globalised world? It seems that this point could be a very delicate element, not only between locals, but at various levels (in planning, design and management). According to the studies of Serge Gruzinski (2016), in which he tried to analyse the sense of the past in the globalised world and the social context on which history acts, is globalisation now a limit for culture, or, on the contrary, has every society his own relation with its history (Hartog 2003)? Landscapes have changed in the last 40 years, also from the point of view of the perception that individuals have of their own cultural references. With this in mind, an enormous challenge opens up, and forces those who deal with these issues to build new value systems also to protect and safeguard, because it is important that locals recognise this knowledge and endorse it.

Secondly, has digital led to an evolution of society in the cultural heritage? As highlighted in this article, the use of digital technologies can promote a critical thinking, creating new experiences to transfer and facilitating students' and citizens' learning. This is very

https://www.youtube.com/watch?v=JztY7MJsRVE\&t=1s. 
important for future construction of institutional and professional identities, and on visitors' experiences within a possible changing in museum practice and archaeological sites. From this point of view, digital technologies are essential for public engagement and the use of immersive and BCI technologies could be a way for (global) communication of memories, feelings and sensations during site-specific visits, becoming very useful techniques for research and education, not only for dissemination.

For the Venetian area, that is so unique, shifting the focus directly on people and to the community itself, making them become protagonists, appears the best solution to express the sense of a very complex and extraordinary landscape like the Venetian one. Is it possible to shift something towards another focus? From a marketing point of view, look at the Swatch company, for example, which transformed the budget-friendly, function-oriented watch-industry into an emotionally-driven fashion statement, or Starbucks which revolutionised the coffee industry by shifting the focus away from selling coffee for everyday use to the emotionally charged atmosphere in which customers enjoy their coffee (Chan Kim, Mauborgne 2015). In this way, not only citizens and the people are included in the research, but also companies and associations in there.

Moreover, from an academic point of view, communities approaching allows to use digital content in a creative and innovative way, to support research and teaching, to enhancing planning possibility and creating cultural paths to support research and dissemination, to develop ability to stimulate the process of learning and research, and the development of skills for cooperative learning. The use of a citizen-science approach facilitates the dialogue, sharing co-produced knowledge and values, and involving citizens in academic research and dissemination of results. In addition, knowledge transfer helps multiple fields including maker culture, co-created inclusive narratives and the construction of a cultural identity.

The other significant point that emerged from the research is that a multidisciplinary approach is absolutely the best solution to be adopted. This approach is based on a continuous dialogue between different skills, often going beyond the boundaries of single disciplines. In this sense, digital and public humanities are an intersection of disciplines that offer promising prospects for future research and an essential resource for knowledge preservation, exchange and dissemination. In this way, it will be possible to improve the general awareness of such environmental and societal threats for a better scenario of the future, through the production of new knowledge. For all of these reasons, embrace the possibilities of interactivity: allow participants to play around with different perspectives, create their own personal stories about an issue, allow them to construct parts of the narration. These are ways to engage not only the public but also stakeholders. 
This is an important time for communications about cultural heritage. We are entering a new era of digital transformation and it is vital for the cultural heritage sector that digital culture secures its place within that future. How can we make and accept meaningful connections? What are the main needs of institutions and the broader community? This article has highlighted four points regarding a good communication:

1. the importance to find an affinity place with an engagement in a common activity;

2. find a way to listen and engage locals and give them interactive/digital alternatives. Experiences and research approaches should be tangible, processes-focused, visible (publishing), viable (foster collaboration and inclusive mechanism, not individual proposal but of the entire team) and adaptable (to changing conditions or shifting contents into a specific methodology, as games);

3. create a dynamic and personalised narration, because learning is considered a process of interactive meaning-making, in which learners continually reshape themselves. This is a very important point to be adopted especially during this pandemic period. The use of a citizen-science approach aims at facilitating dialogue, sharing coproduced knowledge and values, and involving citizens in academic research and dissemination of results;

4. find the right technology. There are indeed many other ways to create participation, especially thanks to digital tools and in particular immersive technologies that could be the best solutions to experiment the way to identify with the environment.

\section{Conclusion}

The final outcomes of this article are both scientific and technological, related to digital communication and public engagement, proving that the main need is to create a knowledge-based heritage for future generations as a resource for regional development and to grow methodologies for an efficient involvement of citizens. Thus, it is necessary to develop dynamic, multidisciplinary and innovative ideas and make creative use of data, media and tools to express and digest complex sets of information, and, therefore, to develop innovative applications that enable communities, individuals and professionals to engage with cultures of the past: from heritage sites to family memories, giving new ways to understand, interpret and share information and models of the past.

In this sense the engagement is based on the different forms of interaction between different cultures and situations that can create differ- 
ent expectations of the engagement. For instance, in storytelling, the listener's role is to create vivid, multi-sensory images, actions, characters, and events of the story in mind, based on the listener's own past experiences, beliefs, and understandings. The completed story happens in the mind of the listener that becomes, therefore, a co-creator of the story as experienced. In this sense, the expectations about listener interaction and the nature of the story itself vary widely.

In this way the landscape history could be a community resource, proposing ways and practices through which the meaning-making processes in the cultural heritage activities can be more inclusive, and contributing to making knowledge even more accessible and engaging for different kinds of audiences towards the scientific community and the public.

To conclude, two important aspects can be highlighted: shifting the focus directly to people and to the community itself, making them become protagonists, and recognise the role of good communication. Communication is indeed a process by which information is exchanged between individuals through a common system. This may sound simple, but communication is actually a very complex subject. The transmission of the message can be affected by a huge range of things, such as our emotions and the cultural situation. An effective communicator understands their audience, chooses an appropriate communication channel and encodes the message to reduce misunderstanding by the receiver(s).

Finally, promoting the interactions between man and environment as a way to respond to today's changes in humans' relationship with the environment can maybe improve people's quality of life. To achieve this, it is important to consider that research could go beyond the academy, including public, private and institutional agents, paying attention to the management of cultural heritage and the intersection between environmental humanities and digital technologies.

\section{Bibliography}

Bartscherer, T.; Coover, R. (eds) (2011). Switching Codes: Thinking Through New Technology in the Humanities and the Arts. Chicago: University of Chicago Press.

Bobrov, P.; Frolov, A.; Cantor, C.; Fedulova, I.; Bakhnyan, M.; Zhavoronkov, A. (2011). "Brain-computer Interface Based on Generation of Visual Images”. PLoS One, 6(6), e20674, 1-12. http://doi.org/10.1371/journal. pone. 0020674 .

Cameron, F.; Kenderdine, S. (2007). Theorizing Digital Cultural Heritage: A Critical Discourse. Cambridge (MA): The MIT Press.

Chan Kim, W.; Mauborgne, R.A. (2015). Blue Ocean Strategy: How to Create Uncontested Market Space and Make the Competition Irrelevant. Boston: Harvard Business Press Books. 
Ciotti, F. (2016). “Digital Heritage/Digital Humanities: una linea di faglia?”. Leggere, scrivere efar di conto, 15 febbraio. https://infouma. hypotheses. org/295.

Cooper, D.D. (2014). "Can Civic Engagement Rescue the Humanities?". Cooper, D.D. (ed.), Learning in the Plural: Essays on the Humanities and Public Life. East Lansing (MI): Michigan State University Press, 151-65.

Corrò, E.; Moine, C.; Primon, S. (2015). "Reazioni uguali e contrarie. Evoluzione paleoambientale e trasformazioni storiche intorno al monastero di Sant'llario e Benedetto (Dogaletto di Mira)", in Gelichi, S. (a cura di), "Costruire territori/costruire identità: lagune archeologiche a confronto tra antichità e medioevo", num. monogr., Reti Medievali, 16(2), 1-49.

Corrò, E.; Moine, C.; Primon, S. (2018). "Setting the Scene: The Role of Sant'Ilario Monastery in Early Medieval Venice in light of recent Landscape Studies". Gelichi, S.; Gasparri, S. (eds), Venice and Its Neighbours from the 8th to 11th Century through Renovation and Continuity. Leiden; Boston: Brill, 116-41.

Corrò, E.; Moine, C.; Primon, S. (2019). "Time Travelling. Multidisciplinary Solutions to Reveal Historical Landscape and Settlements (The Case Study of Sant'llario, Mira, Ve)". Gelichi, S; Olmo Enciso, L. (eds), Mediterranean Landscapes in Post Antiquity: New Frontiers and New Perspectives. Summertown (UK): Archaeopress, 18-37.

Corrò E.; Piovan, S.; Primon, S.; Mozzi, P. (2021). "Dinamiche fluviali e condizionamenti insediativi nel paesaggio di pianura tra la Laguna di Venezia e il fiume Po". Corrò, E.; Vinci, G. (a cura di), Palinsesti Programmati nell'Arco Alto Adriatico? Decifrare, conservare, pianificare e comunicare il paesaggio. Venezia: Edizioni Ca' Foscari, 74-108. http://doi.org/10.30687/97888-6969-480-6/004.

Davies, C. (2003). "Landscape, Earth, Body, Being, Space and Time in the Immersive Virtual Environments Osmose and Ephémère". Malloy, J. (ed.), Women, Art, and Technology. Cambridge (MA): The MIT Press, 322-37.

D'Eredità, A.; Falcone, A.; Pate, D.; Romi, P. (2016). "Strategie di divulgazione dell'archeologia online: metodologie, strumenti e obiettivi. Dalla redazione del piano editoriale alla misurazione dei risultati". Archeologia e Calcolatori, 27, 331-56.

Ellison, J. (2013). "The New Public Humanists". PMLA, 128(2), 289-98.

Emmett, R.S.; Nye, D.E. (2017). The Environmental Humanities. A Critical Introduction. Cambridge (MA): The MIT Press.

Feldman Barrett L. (2011). “Constructing Emotion”. Psychological Topics, 20(3), 359-80.

Feldman Barrett, L. (2017). "The Theory of Constructed Emotion: An Active Inference Account of Interception and Categorization". Social Cognitive and Affective Neuroscience, 12(1), 1-23. https://doi.org/10.1093/scan/ nsw154.

Forte, M.; Murteira, H. (2020). Digital Cities: Between History and Archaeology. Oxford: Oxford University Press. https://doi.org/10.1093/ oso/9780190498900.001.0001.

Gee, J.P. (2004). Situated Language and Learning: A Critique of Traditional Schooling. New York: Routledge.

Gee, J.P. (2005). "Semiotic Social Spaces and Affinity Spaces: From The Age of Mythology to Today's Schools". Barton, D; Tusting, K. (eds), Beyond Communities of Practice: Language, Power and Social Context. Cambridge: Cambridge University Press, 214-32. 
Gruzinski, S. (2016). Abbiamo ancora bisogno della Storia? Il senso del passato nel mondo globalizzato. Milano: Raffaello Cortina Editore.

Hartog, F. (2003). Regimes d'Historicitè: Présentisme et expériences du temps. Paris: Le Seuil. https://doi.org/10.4000/osp.752.

Havelock, E.A. (2019). Cultura orale e civiltà della scrittura. Da Omero a Platone. Roma-Bari: Laterza.

Hayles, N.K. (2012). How We Think: Digital Media and Contemporary Technogenesis. Chicago: University of Chicago Press.

Heinisch, B. (2020). "Citizen Humanities as a Fusion of Digital and Public Humanities?". magazén, 1(2), 143-80. https://doi.org/10.30687/ mag/2724-3923/2020/02/०๑1.

Hieda, N. (2017). "Mobile Brain-Computer Interface for Dance and Somatic Practice". UIST '17: Adjunct Publication of the 30th Annual ACM Symposium on User Interface Software and Technology = Conference Proceedings (Québec, Canada, 22-25 October 2007). New York: Association for Computing Machinery (ACM), 25-6. https://doi.org/10.1145/3131785.3131803.

Johnsson, E. (2006). Telling Tales. A Guide to Developing Effective Storytelling Programmes for Museums. Edited by C. Adler. London: London Museums Hub.

Jones, C.; Severo, M.; Guido, D. (2018). "Towards Innovative Interfaces for Historical and Geographical Thinking: Qualitative Filtering with Co-occurrence Graphs for Geohumanities". Journal of Spatial Information Science, 17, 1-30.

Lazauskas, J.; Snow, S. (2018). The Storytelling Edge: How to Transform Your Business, Stop Screaming into the Void, and Make People Love You. Hoboken (NJ): Wiley.

Lekova, A.; Dimitrova, M.; Kostova, S.; Bouattane, O.; Ozaeta, L. (eds) (2018). "BCl for Assessing the Emotional and Cognitive Skills of Children with Special Educational Needs". IEEE 5th International Congress on Information Science and Technology (CiSt) = Conference Proceedings (Marrakech, Morocco, 21-27 October 2018). Piscataway (NJ): Institute of Electrical and Electronics Engineers (IEEE), 400-3. https://doi.org/10.1109/ CIST.2018.8596571.

Malpas, J. (ed.) (2011). The Place of Landscape: Concepts, Contexts, Studies. Cambridge (MA): The MIT Press.

McGann, J. (2005). "Culture and Technology: The Way We Live Now, What is to be Done?". Interdisciplinary Science Reviews, 30(2), 179-88.

McRobert, L. (2007). Char Davies'Immersive Virtual Art and the Essence of Spatiality. Toronto: University of Toronto Press.

Moine, C.; Corrò, E.; Primon, S. (2017). Paesaggi Artificiali a Venezia. Archeologia e Geologia nelle terre del Monastero di Sant'llario tra alto Medioevo ed Età Moderna. Firenze: All'Insegna del Giglio.

Moshenska, G. (2017). "Introduction: Public Archaeology as Practice and Scholarship where Archaeology Meets the World". Moshenska, G. (ed.), Key Concepts in Public Archaeology. London: UCL Press, 1-13.

Nicolas-Alonso, L.F.; Gomez-Gil, J. (2012). "Brain Computer Interfaces, a Review”. Sensors, 12(2), 1211-79. https://doi.org/10.3390/s120201211.

Nijholt, A. (2019). "Introduction: Brain-Computer Interfaces for Artistic Expression". Nijholt, A. (ed.), Brain Art. Brain-Computer Interfaces for Artistic Expression. Berlin: Springer, 1-29. https://doi.org/10.1007/978-3-03014323-7.

Nussbaum, M. (2010). Not for Profit. Why Democracy Needs the Humanities. Princeton: Princeton University Press. 
Oskooyee, K.S.; Banerjee, A.; Gupta, S.K.S. (unpublished). "Neuro Movie Theatre: A Real-Time Internet-Of-People based Mobile Application". HotMobile '15. 16th International Worskshop on Mobile Computing Systems and Applications $=$ Conference Proceedings (Santa Fe, New Mexico, 12-13 February 2015).

Paradiso, J.A. (1999). "The Brain Opera Technology: New Instruments and Gestural Sensors for Musical Interaction and Performance". Journal of Music Research, 28, 130-49.

Pearlman, E. (2017). "Brain Opera. Exploring Surveillance in 360-Degree Immersive Theatre". PAJ: A Journal of Performance and Art, 39(2), 79-85.

Rogage, K.; Kirk, D.; Charlton, J.; Nally, C.; Swords, J.; Watson, R. (2021). "Memoryscapes: Designing Situated Narratives of Place through Heritage Collections". International Journal of Human-Computer Interaction, 37(11), 102848. https://doi.org/10.1080/10447318.2020.1865004.

Roussou, M.; Servi, K.; Ripanti, F. (2017). "Engaging Visitors of Archaeological Sites Through 'Emotive' Storytelling Experiences: A Pilot at the Ancient Agora of Athens". Archeologia e Calcolatori, 28(2), 405-20.

Sandelowski, M. (1994). "We are the Stories We Tell: Narrative Knowing in Nursing Practice". Journal of Holistic Nursing, 12(1), 23-33. https://doi.org/1 $\odot .1177 / 089801019401200105$.

Sawicki, D.; Wolska, A.; Roslon, P.; Ordysinski, S. (2016). "New EEG Measure of the Alertness Analyzed by Emotiv EPOC in a Real Working Environment". Krebs, H.I.; Pedotti, A.; Faisal, A. (eds), NEUROTECHNIX 2016 = Proceedings of the 4th International Congress on Neurotechnology, Electronics and Informatics (Porto, Portugal, November 7-8, 2016). Setúbal (Portugal): SciTePress, 35-42. https://doi.org/10.5220/0006041200350042.

Schell, J. (2005). "Understanding Entertainment: Story and Gameplay are One". Computers in Entertainment, 3(1), 1-6. https://doi. org/10.1145/1057270.1057284.

Sena, P.; D’Amore, M.; Brandimonte, M.A.; Squitieri, R.; Fiorentino, A. (2016). "Experimental Framework for Simulators to Study Driver Cognitive Distraction: Brake Reaction Time in Different Levels of Arousal". Transportation Research Procedia, 14, 4410-19. https://doi.org/10.1016/j. trpro.2016.05.363.

Severo, M. (2009). Heritage Networks. Managing Network Cultural Heritage with the Web. Saarbrücken: VDM Verlag Dr. Müller.

Swords, J.; Nally, C.; Rogage, K.; Watson, R.; Charlton, J.; Kirk, D. (2020). “Colliding Epistemologies, Productive Tensions and Usable Pasts in the Generation of Heritage-Led Immersive Experiences". International Journal of Heritage Studies, 27, 186-99. https://doi.org/10.1080/13527258.20 20.1780462.

Terras, M.; Nyhan, J.; Vanhoutte, E. (eds) (2013). Defining Digital Humanities. A Reader. Farnham: Ashgate.

Tolja, G. (2013). "Re-Telling, Re-Evaluating and Re-Constructing". The Comics Grid: Journal of Comics Scholarship, 3(1). p.Art. 10. https://www.comicsgrid.com/article/id/350॰/.

Warwick, C.; Terras, M.; Nyhan, J. (eds) (2012). Digital Humanities in Practice. London: Facet.

Zak, P.J. (2015). "Why Inspiring Stories Make Us React: The Neuroscience of Narrative". Cerebrum: The Dana Forum on Brain Science, 2. https://www. ncbi.nlm.nih.gov/pmc/articles/PMC4445577/. 



\title{
Knowledgescape
}

Insights on Public Humanities

edited by Eugenio Burgio, Franz Fischer, Marco Sartor

\section{Le Ortique: un progetto collettivo e digitale per riscoprire le artiste dimenticate}

\section{Alice Girotto}

Università Ca' Foscari Venezia, Italia

\author{
Alessandra Trevisan \\ Università Ca' Foscari Venezia, Italia
}

\begin{abstract}
Le Ortique or of the Deformed Canon is a collective and digital project that aims to give a second voice to forgotten female writers and artists of the 20th century. The project revolves around a blog where the eight founders, who are authors themselves as well as scholars, publish critical readings of works in poetry and prose, unpublished translations, interviews, podcasts, online and live events, musical interpretations and visual works. The aim of this article is to thoroughly present the project in its conceptual foundations, tangible outcomes and international connections, while highlighting its novelty in the context of other similar projects aiming at questioning and deconstructing literary canons.
\end{abstract}

Keywords Literarycanons. Women writers. Women artists. Contemporary literature. Dissemination. 20th century. 
'Le Ortique' ovvero del canone deformato è un progetto collettivo e digitale che muove dall'intento di ridare una seconda voce a scrittrici e artiste dimenticate del Novecento, di varia provenienza geografica di ambito internazionale. Il nome evocativo scelto richiama non solo la pianta dell'ortica, nota proprio per l'effetto di prurito che essa produce, analogo al 'disturbo' che la voce delle donne ha creato nel tempo e che ancora oggi crea, ma anche l'obliquità, l'intersezione non lineare, spesso tortuosa e raramente definitiva dell'opera delle donne con i canoni artistici e letterari dei più disparati contesti nazionali. ${ }^{1}$ Come recita il manifesto scritto a più mani, il gruppo, di cui le due autrici di questo articolo fanno parte:

si propone di ripensare [...] a tutte quelle protagoniste mancate - artiste, scrittrici, poete - che per diverse ragioni non sono riuscite a vivere e sopravvivere al loro tempo. Siamo consapevoli infatti che le loro visioni, il loro immaginario, la loro poetica risuonino ancora di significato e sarebbe davvero imperdonabile dimenticarle nel silenzio degli archivi, lasciandole ancora una volta senza volto e senza voce.

Il progetto si organizza intorno a un blog (https://leortique. wordpress.com) che raccoglie articoli, letture critiche di opere in poesia e in prosa, interventi di studiosi esperti, traduzioni inedite da più lingue, interviste, podcast, eventi online e live, interpretazioni musicali e opere visive, la cui pubblicazione a cadenza trimensile viene divulgata attraverso i social network del gruppo e delle singole autrici: Alessandra Trevisan, Alice Girotto, Chiara Pini, Clelia Lombardo, Daita Martinez, Francesca Fiorentin, Veronica Chiossi e Viviana Fiorentino.

Ci si potrebbe chiedere qual è l'apporto nuovo di un progetto come questo a un panorama che non manca di iniziative che muovono specificamente da un ambito accademico per avere ricadute in ambiti di divulgazione: dalla Società Italiana delle Letterate, fondata nel 1996, agli studi sull'Oltrecanone di Anna Maria Crispino (2003); da Server Donne legato a Women.it alla Biblioteca delle Donne di Bologna e all'Archivio di Storia delle Donne, operante dai primi an-

1 La trasversalità dell'esclusione più o meno relativa delle donne dal canone letterario in relazione a diversi contesti nazionali è stata approfondita in particolare dal convegno Women and the Canon tenutosi presso l'Università di Oxford il 22 e 23 gennaio 2016 (si veda https://womenandthecanon.wordpress.com/call-for-papers/programme/). Per ragioni legate agli ambiti disciplinari in cui operano le due autrici del presente articolo, gli esempi in questo senso qui e più avanti nel testo faranno riferimento esclusivamente al contesto italiano e a quello portoghese. Per quanto riguarda il primo, uno studio importante sull'esclusione delle donne dal canone letterario è quello di Bazzoni e Riboli (2016); per il contesto portoghese, si veda almeno Edfeldt 2006; 2008; 2019; Klobucka 2008; Vicente, Vicente 2015. 
ni Duemila; dal progetto di ricerca Scrittrici e intellettuali del Novecento, che dagli anni Novanta ha condotto ricerche su numerose voci di autrici italiane (e facente capo a Marina Zancan presso la Sapienza Università di Roma), ${ }^{2}$ da cui si è concretizzato il prezioso lavoro di Alessia Scacchi Bibliografia delle autrici del Novecento, sino alle «eccentriche» di Anna Botta, Monica Farnetti, Giorgio Rimondi (2003); dall'omonimo progetto digital di Sara de Simone, eccentriche (dal 2017), sino alle iniziative di festival tra cui inQuiete curato dalla libreria Tuba Bazar di Roma (dal 2018). ${ }^{3}$

Due sono, a nostro parere, i perni fondamentali attorno ai quali ruota l'originalità del progetto Le Ortique, l'uno implicato dall'altro: innanzitutto, l'autorialità stessa della maggior parte delle componenti del gruppo fa sì che gli interrogativi sulla marginalità della letteratura scritta da donne nei vari canoni letterari, ${ }^{4}$ nazionali o sovranazionali, nascano da un'esperienza vissuta in prima persona; la scrittura come atto creativo 'mobile', perciò, definisce una pratica esperienziale e conoscitiva insieme, fatto che determina scelte, direzioni e implicazioni. Da ciò deriva l'approccio non soltanto teorico a queste questioni, ma anche empirico, frutto di letture e incontri personali, di evidenze nella pratica lavorativa quotidiana di chi di noi è insegnante e docente ma anche studiosa, di scoperte fatte in contesti nazionali diversi ma in cui i problemi sembrano replicarsi con ostinata pervicacia. Il primo livello esperienziale è, secondo il nostro punto di vista, in grado di dare substrato al livello secondo, metodologico, rivolto all'indagine critica e linguistica del lavoro delle autrici che scegliamo di trattare.

Anche in questo senso la dimensione di canone, che già è posta come problematica da tutti i gruppi di ricerca citati in preceden-

2 Si rimanda a http://scrittrici900.uniroma1.it/ricerche.php.

3 Un esempio analogo ai gruppi italiani per quanto riguarda il contesto portoghese è il lavoro del Centro de Cultura e Intervenção Feminista (CCIF) dell'União de Mulheres Alternativa e Resposta (UMAR), che quest'anno completa la sua prima decade di vita e che si è distinto per il recupero della memoria delle donne nel campo delle arti. Questo obiettivo, incarnato fin dalla genesi del centro nella sua stessa missione, viene conseguito attraverso una programmazione culturale settimanale. Al momento in Portogallo non esistono altri progetti con lo stesso livello di continuità, ma solo azioni puntuali in questo senso, come ad esempio i tre cicli di conferenze sulla letteratura scritta da donne organizzate dalla Biblioteca nacional nell'ambito della linea di ricerca Storia delle donne e del genere del centro di ricerca CHAM dell'Universidade Nova di Lisbona, per la quale si rimanda a http://cham.fcsh.unl.pt/lintem_show.aspx?lintem=9.

4 Le accezioni di canone letterario alle quali ci rifacciamo sono quelle ricordate da Luperini (1998) ossia, da un lato, le norme, 'codificate' a partire da determinate opere, che fondano una tradizione letteraria nazionale e fungono perciò da modello (anche polemico) per l'elaborazione di opere successive e, dall'altro, i valori di riferimento stabiliti dalla ricezione, quelli che la comunità dei lettori, nelle diverse epoche storiche, ritiene imprescindibili per l'evoluzione del proprio gusto e della propria cultura e che si sono tradotti, soprattutto nell'ultimo secolo e mezzo, «nell'elenco dei libri di cui si prescrive la lettura nell'ambito delle istituzioni educative» (11). 
za, secondo il nostro punto di vista deve esplodere per decostruirsi. 'Deforming the canon', dunque, è una prospettiva congeniale per modificare la visione e la lettura dei canoni occidentali, ampliandone la capacità contenitiva e incidendo sul criterio di scelta falsato che ha generato, nel tempo, la continua esclusione delle artiste dal panorama di studi e ricezione.

Secondo quanto detto non possiamo definirci militanti della critica di genere, perché la maggior parte di noi non ha un background di formazione accademica in discipline letterarie e, quand'anche lo avesse e praticasse la ricerca in questo ambito, non ha avuto nel proprio percorso di formazione l'occasione di confrontarsi, in senso stretto, con la teoria femminista, che sentiamo dunque laterale rispetto ad altri metodi che hanno radici nella nostra esperienza, come, ad esempio, l'analisi del testo e linguistica, la critica testuale, la ricerca d'archivio, la filologia e la pratica di traduzione - come nel caso di chi scrive. Pur riconoscendo che la scommessa femminista sussiste nella creazione di qualunque progetto che intenda far uscire dal silenzio la voce di donne-artiste dimenticate, la convinzione che condividiamo, infatti, è che certe domande predeterminate dalla teoria comportino il rischio di sovrainterpretare le realtà oggetto di studio e di 'far dire' ai testi cose altre rispetto a quelle che vi sono contenute, di esprimere cioè soprattutto il punto di vista del critico e meno quello dell'autrice, a meno che proprio l'autrice non abbia aderito in vita, con le sue parole, al contesto del femminismo o a un contesto politico. Ė per questo che abbiamo scelto di lasciare aperto il campo delle possibilità di scelta di ciascuna di noi senza abbracciare - in senso stretto - le linee dei gender studies e degli women's studies che intersecano l'esperienza di alcune e fanno spesso parte del bagaglio degli studiosi esterni che intervengono sul blog, pur ritenendo che il silenziamento della voce delle donne così come l'oblio di molte scrittrici e artiste abbia una radice sociale e politica come rilevato anche da Anna Banti, la quale affermava:

Sono citata nelle enciclopedie, sono presente nelle antologie. Ma una scrittrice, anche se di successo, è comunque emarginata. La diranno grande fra le altre scrittrici, ma non la equipareranno agli scrittori. Ė un'usanza diffusa. (Petrignani 1996, 106; cit. in Storini 2020, 18)

Facendo affidamento al testo scegliamo di vagliare nel tempo le teorie che eventualmente possano aderire all'una o all'altra voce presa in esame, colmando così le nostre lacune e prospettive qualora l'autrice lo richieda. Non intendiamo questo come un approccio naif, né epurato di un lungo corso di ricerche fruttuose e rilevanti, ma scegliamo consapevolmente l'osservazione di un panorama vario come 'azione fondante' di un nostro metodo, in grado di guardare oltre l'in- 
terpretazione stringente. Crediamo, dunque, che leggere il testo e il contesto resti una pratica più inclusiva di altre. ${ }^{5}$

A questo livello riteniamo che la ricerca di una nostra identità come collettivo che indaga e fa divulgazione debba necessariamente passare per una concertazione di pratiche diverse, alcune volte eterogenee, che ciascuna mette in atto nel lavoro di gruppo e non sempre rispecchiano l'approccio di tutte. Ciò implica anche un avvicinamento a percorsi noti già tracciati da altri e un parziale affrancamento per meglio esplorare quali modalità si confanno al gruppo, dal momento che la relazione tra autrici sottende in primo luogo la consapevolezza di riuscire a definire come i nostri percorsi si intersechino e restituiscano all'esterno una visione unitaria. La radice che nasce nella dimensione creativa ammette la scoperta e lo studio come atto di passaggio attraverso cui l'idea si concreta; per questa ragione l'autorialità rafforza un punto di vista altro sull'oggetto di studio, in questo caso il lavoro delle autrici dimenticate di cui ci occupiamo.

Abbiamo scelto consapevolmente l'esercizio pubblico - attraverso il blog e un uso di altri strumenti di comunicazione tra cui i social media - per aprirci a una modalità che possa conciliarsi e scontrarsi con l'esistente, che possa nutrirsi innanzitutto di sé e, in seconda battuta, di relazioni con l'esterno, con il pubblico e con altre realtà che possano interloquire con noi.

Siamo consapevoli del fatto che gli strumenti di ricerca di chi proviene da un approccio non accademico sostengano a più riprese le possibilità del collettivo, perché sono in grado di mettere in discussione il metodo acquisito e di fare da contraddittorio a un sistema determinato: in altri termini di smontare, rimontare e sovvertire un ordine. Siamo certe, inoltre, che nello 'sperimentare' il legame tra parola, voce, musica e immagine tra arti visive e performative esi-

5 Un caso che ben testimonia la complessità della ricezione della letteratura scritta da donne, all'interno e a maggior ragione all'esterno dei propri confini nazionali, e dell'intreccio in questo percorso di ragioni estetiche, strettamente legate al testo, e ragioni politiche è quello delle Nuove lettere portoghesi, opera del 1972 scritta a sei mani da Maria Isabel Barreno, Maria Teresa Horta e Maria Velho da Costa. Il volume, che viene considerato da alcuni fra i più importanti critici della letteratura portoghese come un contributo fondamentale alla trasformazione del rigido contesto socio-politico del paese iberico negli anni che precedettero il ritorno della democrazia, resta tuttavia «un libro più conosciuto che letto» e che «non è [quasi] mai stato oggetto di corsi nelle università portoghesi», sebbene la vicenda giudiziaria che coinvolse le tre autrici in seguito alla censura da parte del regime abbia assunto la rilevanza di «prima causa femminista internazionale». La pratica di rilettura di questo testo in lingua originale e in traduzione (in occasione della partecipazione delle Ortique al Carta Carbone Festival di Treviso, il 17 ottobre 2020, e del video contest Till I To - Voicing Forgotten Women Artists di Paris Lit Up, il 5 febbraio 2021) e del suo contesto di riferimento (nei due post https://bit.ly/2VZswZb e https://bit.ly/3rpFfQG) mira proprio a farne conoscere la forza di rottura, estetica e politica insieme, a un pubblico auspicabilmente sempre più vasto. 
stano e resistano trame inedite; aderiamo a un orizzonte di studi definito e peculiare, in cui tentiamo di porre al centro «the actions and processes of artistic creation as part of [Digital Humanities] praxis and epistemic universe» (Rodríguez Ortega 2018, 2) attraverso percorsi sconosciuti, che possano scrivere il presente-futuro del gruppo continuamente, non sconfinando ma restando sotto la lente dell'inclusione. È in una soluzione che oltrepassa i limiti a noi noti ma li ingloba, riversando al proprio interno i significati, che si svolge il dibattito in cui siamo immerse: perché lo scambio fecondo di testi, opere e relazioni si nutre di una prossimità d'immaginazione che fa da filtro e sistema allo stesso tempo.

Crediamo nella rete periferica della decostruzione dei canoni - una rete menzionata a dicembre 2020 anche dalla scrittrice Nadia Terranova insieme a ben più longevi collettivi, tra cui la Società Italiana delle Letterate (SIL) e il loro bollettino informativo, Letterate Magazine -, così com'è periferico il nostro approccio poiché indirizzato ad aree minime: da lingue 'minori' ad artiste certamente sconosciute anche di letterature che non sempre godono di collocazioni di primo piano. E risulta del tutto congruo comportare, agire e segnare simbolicamente anche un destino armonico: scegliendo appunto 'le ortiche' come pianta urticante con proprietà medicamentose e l'obliquità come direzione che sentiamo più del 'minore' in letteratura, tentiamo una disposizione diversa delle nostre singole parti, che possa esprimersi come 'poeticamente' coerente.

L'esistenza digitale permette di affrontare la pratica della divulgazione adattandola ai tempi che viviamo, oltre a veicolare una conoscenza che la rete spinge ai limiti dello spazio. In questo senso gli eventi di lancio del progetto, ossia l'open mic online e il podcast fest di giugno e luglio 2020, hanno visto alternarsi poete e poeti, studiose e studiosi, lettrici e lettori attenti, con una formazione varia - e in prevalenza umanistica - secondo uno schema molto d'uso in ambiente anglosassone: quello di dare la parola a voci varie senza ingabbiarle nelle forme. Narrare, raccontare, è stato il filo conduttore, così come il reading. Gli eventi hanno avuto successo, con circa una trentina di partecipanti e un centinaio di persone dal pubblico a seguire. La pagina Facebook ha, ad oggi, più di 1.000 like e più di 350 sono i follower su Instagram. Le Ortique non si colloca in una dimensione pop dell'influencing, ma si lega alla pratica della disseminazione e del Public Engagement così com'è propria anche della Terza Missione in ambito accademico. Fra le altre, la scelta di veicolare alcuni dei propri contenuti tramite podcast è illustrativa in questo senso: anche laddove la loro produzione si è diffusa maggiormente nel 2020, quando la pandemia di COVID-19 ha reso necessaria la creazione di contenuti audio di tipo scientifico e divulgativo dal momento che le occasioni di incontro pubblico si sono pressoché azzerate, il gruppo ha ripristinato una pratica appresa in anni lontani, ad esem- 
pio in diverse esperienze svolte presso la web radio dell'Ateneo veneziano, Radio Ca' Foscari.

Importanti sono poi le reti di scambio con altri gruppi e realtà simili: in Irlanda, grazie a Viviana Fiorentino, Le Ortique collabora con il collettivo attivista nordirlandese Letters with Wings, che si batte a favore di artisti e attivisti reclusi in tutto il mondo. In Francia il nostro gruppo collabora con il collettivo Paris Lit Up che, dal 2013, riunisce artisti anglofoni di base o di passaggio a Parigi. C'è dunque, nel nostro intento, quello di unire ricerca, impegno e comunicazione.

La nascita sul web, come dicevamo, è avvenuta a metà giugno del 2020 e subito si è caratterizzata per un respiro internazionale, con l'intervista alla co-fondatrice del gruppo irlandese Fired!, che si propone di mettere in discussione il canone letterario irlandese; a essa è seguita la presentazione di Eavan Boland, una delle più grandi poete d'Irlanda recentemente scomparsa. ${ }^{6}$ Il lavoro sul canone italiano inizia subito dopo, con il recupero della produzione poetica della scrittrice siciliana Livia De Stefani attraverso un'introduzione critica di Alessandra Trevisan, un podcast collettivo a nove voci in cui abbiamo letto alcuni componimenti dalla raccolta postuma Poesie in diesis (2002) e un'interpretazione critica da parte di Francesca Clara Fiorentin. ${ }^{7}$ Sempre Francesca Clara Fiorentin ha poi approfondito la produzione in prosa della De Stefani rintracciando i caratteri di un femminismo e di un ecologismo ante litteram in romanzi come La vigna di uve nere (1953), La stella assenzio (1985) o nella raccolta di racconti Viaggio di una sconosciuta (1963) recentemente riedito da Cliquot. ${ }^{8}$ Infine, sulle poesie di Livia De Stefani è nuovamente tornata Chiara Pini, che legge Lochicello, com'era, Il giardino dell'Orecchio di Dioniso a Siracusa e Un'alba a Vizzì, mia terra, le analizza e interpreta attraverso lo strumento della grammatica valenziale e ne trae ispirazione per due opere di caviardage o 'parole in trama'. 9

Questo esempio che abbiamo deciso di presentare, ossia il lavoro a più mani e voci su una stessa scrittrice, vuole essere significativo di quest'altra modalità di divulgazione che ci è propria: non tanto e non solo la poliedricità di sguardi su una medesima opera, ma

6 Un altro importante contributo sulla letteratura irlandese è stata l'intervista alla professoressa Lucy Collins (University College Dublin) sul suo lavoro di riscoperta della poesia di Freda Laughton, il cui lavoro negli anni Quaranta del Novecento è stato al centro della nuova poesia irlandese. Corredano l'intervista tre interpretazioni musicali per voce dei componimenti Now I am a Tower of Darkness, In a Strange December e The Woman with Child. Si veda https://bit.ly/3zmNpfA.

7 Si veda https://leortique.wordpress.com/2020/๑7/01/livia-de-stefani-poesia-per-ritornare-alla-poesia/.

8 Siveda https://leortique.wordpress.com/2020/09/21/livia-de-stefani-narratrice-femminista-ed-ecologista-ante-litteram/.

9 Si veda https://bit.ly/3eDHn1S. 
un approccio collaborativo ${ }^{10}$ alla costruzione dei contenuti che veicoliamo, in cui le nostre otto, singole traiettorie di autrici e artiste, traduttrici e studiose si intersecano e convergono. Altri esempi di questo approccio si possono ritrovare nelle interviste a quattro mani delle rubriche «Parallax», a esponenti di altre arti, e «Latitudini», ad autrici da tutto il mondo che scrivono in una lingua diversa da quella madre, o ancora negli interventi provenienti da ospiti esterni, come l'attenta presentazione dell'opera della poeta greca Khoralia Theotoka, ${ }^{11}$ l'articolo corale su Alice Ceresa ${ }^{12}$ e l'approfondimento sulla poliedrica artista inglese Mina Loy. ${ }^{13}$ Meritano, infine, una menzione a parte i podcast, diffusi tramite il blog e supportati dalla piattaforma SoundCloud, che non sono solo un canale attraverso cui si concretizza la multimedialità del progetto, ma sono anche il mezzo tramite il quale prende corpo, letteralmente, il «comunicarsi delle voci» enunciato da Cavarero $(2003,215)$. Sono in gioco qui la pluralità data dal collettivo e dalle molteplici collaborazioni e, allo stesso tempo, la relazionalità, la «reciprocità orizzontale della risonanza» (Cavarero 2003, 216) del registro vocalico: della voce delle lettrici viventi con la 'voce' poetica delle scrittrici recuperate; di lingue diverse che risuonano attraverso voci diverse o che si fanno spazio nella grana della medesima voce; dello stesso testo poetico che prende forma melodica nel canto e cadenzata nella lettura che segue il ritmo del verso. Ė, quest'ultimo, il caso di tre componimenti della poetessa irlandese Freda Laughton, restituiti nell'interpretazione musicale per voce e nella lettura in traduzione di Alessandra Trevisan e Viviana Fiorentino. ${ }^{14}$

Vogliamo concludere citando le parole di una delle autrici che sono intervenute nel nostro blog, la portoghese Judite Canha Fernandes, intervistata da Alice Girotto anche come atto di riconoscenza personale al contributo che le conversazioni con questa scrittrice danno per rispondere alla domanda: perché nei programmi di letteratura dei corsi universitari così poche scrittrici sono degnate della stessa attenzione riservata ai colleghi scrittori? Judite afferma:

10 Logica collaborativa che è peraltro fondante del farsi stesso delle Digital Humanities come disciplina (Rodríguez Ortega 2018) e che rimanda a pratiche 'ecologiche' di produzione epistemica (Meneses, Nunes, Santos 2007; Ortega 2019).

11 A cura di Natasha Remoundou; si veda https://bit.ly/2UAgXaH e https://bit. ly/2TsvHrC.

12 A cura di Anna Franceschini, Giusi Montali e Patrizia Zappa Mulas; si veda https://leortique.wordpress.com/2021/01/18/alice-ceresa/. Ci si riferisce anche a Ceresa 2020 e Fortini, Pigliaru 2020.

13 A cura di Laura Scuriatti, docente presso il Bard College Berlin; si veda https:// bit.ly/36NeKLD e Scuriatti 2019.

14 Si veda https://bit.ly/3eFg7jo. 
Sono sicura che il canone non è, non è mai stato, la letteratura in toto prodotta in qualsiasi epoca, nemmeno la migliore, è soltanto ciò che la critica ha valorizzato, o ciò che, in qualche modo, è riuscito a entrare nella corrente mainstream.

\section{E ancora:}

per il fatto che la scrittura è stata vietata o resa difficile alle donne per molti secoli, allo stesso modo in cui lo è stato per gli strati più poveri della popolazione, per chi si trovava fuori dai 'centri intellettuali', ecc., è diminuita la diversità delle voci e la polifonia che la letteratura poteva avere. Questo sta cambiando nel tempo, e per fortuna. ${ }^{15}$

Quello che, come Ortique, facciamo è inserirci in questo cambiamento in atto per ampliarne e potenziarne la portata, raggiungere, anche a partire dalla critica che svolgiamo all'interno dell'università, porzioni di società che non sono (o non sono più) a stretto contatto con l'istituzione universitaria e risvegliare anche in chi opera nel mainstream un'azione di cui le cronache editoriali più recenti sottolineano ancora una volta l'urgente necessità. ${ }^{16}$

\section{Bibliografia}

Bazzoni, A.; Riboli, V. (2016). «Women and the Italian Literary Canon. A Snapshot of the Current Situation in Italian Studies and High School Manuals». Women and the Canon International Conference (University of Oxford, 2223 January 2016). https://womenand thecanon.wordpress.com/callfor-papers/programme.

Botta, A.; Farnetti, M.; Rimondi, G. (2003). Le eccentriche. Mantova: Tre Lune.

Cavarero, A. (2003). A più voci. Filosofia dell'espressione vocale. Milano: Feltrinelli.

Ceresa, A. (2020). Piccolo dizionario dell'inuguaglianza femminile. A cura di T. Crivelli. Milano: Nottetempo.

Crispino, A.M. (2003). Oltrecanone. Roma: manifestolibri.

15 Si veda https://bit.ly/3eB6hPV.

16 Si fa qui riferimento alle dichiarazioni dell'editore Alessandro Laterza, che il 22 novembre 2020 ha dichiarato su Twitter di cercare lumi sulle scrittrici italiane contemporanee al di là di Ginzburg e di Morante - rimarcando che «[e]ssere scrittori è altro dal saper scrivere bene: è avere uno 'stile', un proprio uso del lessico, sintassi, figure retoriche, ecc.» e così sottintendendo, maschilisticamente, una qualche minorità delle donne in questo ambito -, e all'acceso dibattito che ne è seguito in rete. Si veda, a titolo di esempio, https://www.repubblica.it/cultura/2020/11/23/news/alessandro_laterza_accende_la_polemica_su_twitter-275439418/. 
Edfeldt, C. (2006). Uma história na História. Representações da autoria feminina na história da literatura portuguesa do século XX. Montijo: Câmara Municipal do Montijo.

Edfeldt, C. (2008). Mulheres que escrevem mulheres que lêem. Repensar a literatura pelo género. Lisboa: 101 Noites.

Edfeldt, C. (2019). «Early Twentieth-Century Portuguese Feminist Writers as Transnational Cultural Mediators. Virgínia de Castro e Almeida and Ana de Castro Osório». Portuguese studies, 35(2), 167-84.

Fortini, L.; Pigliaru, A. (2020). Abbecedario della differenza. Omaggio ad Alice Ceresa. Milano: Nottetempo.

Klobucka, A.M. (2008). «Sobre a hipótese de uma herstory da literatura portuguesa». Veredas, 10, 13-25.

Luperini, R. (1998). «ll canone del Novecento e le istituzioni educative». Merola, N. (a cura di), Il canone letterario del Novecento italiano. Soveria Mannelli: Rubbettino, 11-21.

Meneses, M.P.; Nunes, J.A.; Santos, B. (2007). «Opening Up the Canon of Knowledge and Recognition of Difference». Santos, B. (ed.), Another Knowledge is Possible. Beyond Northern Epistemologies. London: Verso, xix-lxii.

Ortega, É. (2019). «Zonas de contacto. A Digital Humanities Ecology of Knowledges». Gold, M.K.; Klein, L.F. (eds), Debates in the Digital Humanities 2019. Minneapolis: University of Minnesota Press, part II, chapter 15. https:// dhdebates.gc.cuny.edu/read/untitled-f2acf72c-a469-49d8be35-67f9acle3a60/section/aeee46e3-dddc-4668-a1b3c8983ba4d70a.

Petrignani, S. (1996). «La sfortuna di essere seri». Petrignani, S., Le signore della scrittura. Firenze: La Tartaruga, 101-9.

Rodríguez Ortega, N. (2018). «Five Central Concepts to Think of Digital Humanities as a New Digital Humanism Project», in «Digital Humanities. Societies, Policies, Knowledge», monogr. no., Artnodes, 22, 1-6. http://dx.doi. org/10.7238/a.v0i22.3263.

Sacchi, A. (2020). Bibliografia delle autrici del Novecento. Firenze: Franco Cesati Editore.

Scuriatti, L. (2019). Mina Loy’s Critical Modernism. Gainesville (FL): University Press of Florida.

Storini, M.C. (2020). "Scrittura delle donne: canoni, bibliografia e contronarrazioni». Sacchi, A., Bibliografia delle autrici del Novecento. Firenze: Franco Cesati Editore, 17-26.

Vicente, A.; Vicente, F.L. (2015). «Fora dos cânones. Mulheres artistas e escritoras no Portugal de príncipios do século XX». Faces de Eva. Estudos sobre a Mulher, 33, 38-51. http://www.scielo.mec.pt/scielo.php?scrip-

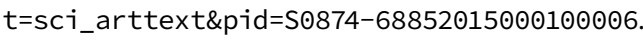




\section{Filologie medievali e moderne}

1. Buzzoni, Marina; Cammarota, Maria Grazia; Francini, Marusca (a cura di) (2013). Medioevi moderni - Modernità del Medioevo. Serie occidentale 1.

2. Bampi, Massimiliano; Buzzoni, Marina (eds) (2013). Textual Production and Status Contest in Rising and Unstable Societies. Serie occidentale 2.

3. Capezio, Oriana (2013). La metrica araba. Studio della tradizione antica. Serie orientale 1.

4. Lombardo, Luca (2013). Boezio in Dante. La Consolatio philosophiae nello scrittoio del poeta. Serie occidentale 3.

5. Burgio, Eugenio; Simion, Samuela (a cura di) (2015). Giovanni Battista Ramusio. Dei viaggi di Messer Marco Polo. Edizione critica digitale progettata e coordinata da Eugenio Burgio, Marina Buzzoni, Antonella Ghersetti. Serie occidentale 4.

6. Ghidoni, Andrea (2015). Per una poetica storica delle chansons de geste. Elementi e modelli. Serie occidentale 5.

7. Bampi, Massimiliano; Buzzoni, Marina; Khalaf, Omar (a cura di) (2015). La Bibbia nelle letterature germaniche medievali. Serie occidentale 6 .

8. Alessio, Gian Carlo; Bognini, Filippo (a cura di) (2015). Lucidissima dictandi peritia. Studi di grammatica e retorica medievale. Serie occidentale 7.

9. Baglioni, Daniele; Tribulato, Olga (a cura di) (2015). Contatti di lingue - Contatti di scritture. Multilinguismo e multigrafismo dal Vicino Oriente Antico alla Cina contemporanea. Serie occidentale 8.

10. Gizzi, Chiara (a cura di) (2016). Piero della Francesca, "De prospectiva pingendi". Serie occidentale 9.

11. Bognini, Filippo (a cura di) (2016). Nuovi territori della lettera tra XV e XVI secolo = Atti del Convegno internazionale FIRB 2012 (Venezia, 11-12 novembre 2014). Serie occidentale 10.

12. Simion, Samuela (a cura di) (2016). Luigi Foscolo Benedetto, "Livre de messire Marco Polo citoyen de Venise, appelé Milion, où sont décrites les Merveilles du monde". Traduzione critica secondo le carte inedite del lascito di Ernest Giddey. Serie occidentale 11 . 
13. Grande, Francesco (2016). Il lessico coranico di flora e fauna. Aspetti strutturali e paleolinguistici. Serie orientale 2.

14. Al-Tawhīìi, Abū Ḥayyān; Miskawayh, Abū 'Alī (2017). Il libro dei cammelli errabondi e di quelli che li radunano. Cura e traduzione di Lidia Bettini. Serie orientale 3.

15. Alessio, Gian Carlo; Losappio, Domenico (a cura di) (2018). Le "poetriae" del medioevo latino. Modelli, fortuna, commenti. Serie occidentale 12.

16. Eusebi, Mario; Burgio, Eugenio (a cura di) (2018). Marco Polo. "Le Devisement dou monde". Serie occidentale 13.

17. Cammarota, Maria Grazia (a cura di) (2018). Tradurre: un viaggio nel tempo. Serie occidentale 14 .

18. Lombardo, Luca; Parisi, Diego; Pegoretti, Anna (a cura di) (2018). Theologus Dantes. Tematiche teologiche nelle opere e nei primi commenti. Serie occidentale 15.

19. Orsatti, Paola (2019). Materials for a History of the Persian Narrative Tradition. Two Characters: Farhād and Turandot. Serie orientale 4.

20. Simion, Samuela (a cura di) (2019). Marco Polo. Il "Devisement dou monde" nella redazione veneziana $V$. Tomo 1 . Serie occidentale 16.

21. Conte, Maria; Montefusco, Antonio; Simion, Samuela (a cura di) (2020). «Ad consolationem legentium». Il Marco Polo dei Domenicani. Serie occidentale 17.

22. Grévin, Benoît (2020). Al di là delle fonti 'classiche'. Le Epistole dantesche e la prassi duecentesca dell'ars dictaminis. Serie occidentale 18.

23. Bianchi, Marco (2020). Galileo in Europa. La scelta del volgare e la traduzione latina del Dialogo sopra i due massimi sistemi. Serie occidentale 19.

24. Dotto, Diego; Falvay, Dávid; Montefusco, Antonio (a cura di) (2021). "Le Meditationes vitae Christi" in volgare secondo il codice Paris, BnF, it. 115. Edizione, commentario e riproduzione del corredo iconografico. Serie occidentale 20. 

This volume, which collects the proceedings of the international study day Intersections. New Perspectives for Public Humanities, aims at shedding light on the often complicated and chaotic 'texture' of public humanities in order to foster a less marginal place for this field of study. The choice to focus the analysis on a selection of case studies that includes history, cultural heritage, archaeology, and literature leads to redesigning a profile whose main feature is to create bridges between specialised knowledge domains and large audiences and identifying methods and models that can make humanistic knowledge 'actionable' in our society.

Università

Ca'Foscari

Venezia 